Portland State University

PDXScholar

$11-5-1996$

\title{
The Politics of Nazi Art: The Portrayal of Women in Nazi Painting
}

Jennifer Anne Miller

Portland State University

Follow this and additional works at: https://pdxscholar.library.pdx.edu/open_access_etds

Part of the History Commons

Let us know how access to this document benefits you.

Recommended Citation

Miller, Jennifer Anne, "The Politics of Nazi Art: The Portrayal of Women in Nazi Painting" (1996).

Dissertations and Theses. Paper 5157.

https://doi.org/10.15760/etd.7033

This Thesis is brought to you for free and open access. It has been accepted for inclusion in Dissertations and Theses by an authorized administrator of PDXScholar. Please contact us if we can make this document more accessible: pdxscholar@pdx.edu. 


\section{THESIS APPROVAI}

The abstract and thesis of Jennifer Anne Miller for the Master of Arts in History were presented November 5, 1996 and accepted by the thesis committee and the department.

COMMITTEE APPROVALS:

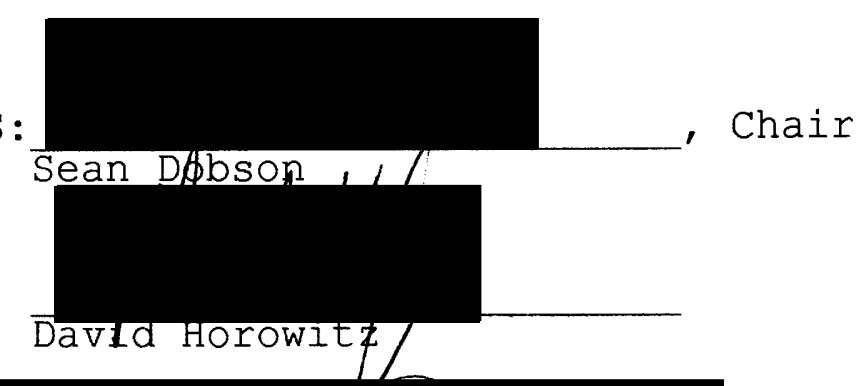

Michael Reardon

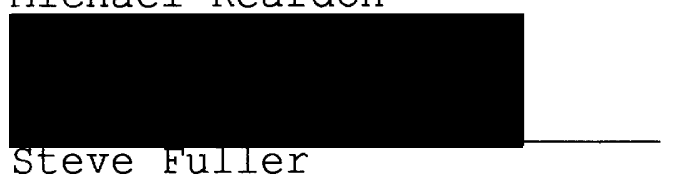

Representative of the Office of Graduate Studies

DEPARTMENT APPROVAL:

Gordon Dodds, Chair

Department of History

ACCEPTED FOR PORTLAND STATE UNIVERSITY BY THE LIBRARY
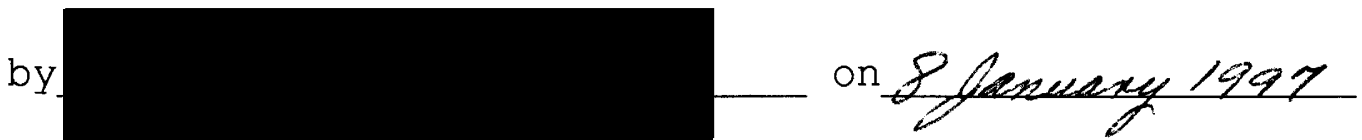


\section{ABSTRACT}

An abstract of the thesis of Jennifer Anne Miller for the Master of Arts in History: Presented November 5, 1996.

Title: The Politics of Nazi Art: The Portrayal of Women in Nazi Painting.

The study of Nazi art as an historical document provided an effective measure of Nazi political platform and social policy. Because the ideology of the Third Reich is represented within Nazi art itself, it is useful to have a good understanding of the politics and ideology, surrounding the German art world at the time. Women were used in this study as an exemplification of Nazi art. This study uses the subject of women in Nazi painting, to show how the ideology is represented within the art work itself.

It was first necessary to understand the fervorent "cleansing" of the German art world initiated by the Nazis. The Nazis too effectively stamped out all forms of professional art criticism, and virtually changed the function of the art critic to art editor. The 
nazification of the German artist was "necessary" in order for the Nazis to enjoy total control over the creation of German art. With these three steps taken in the "cleansing" of the German art world, the Nazis made sure that the creation of a "true" Germanic art would go forth completely unhindered.

In order to comprehend the subject of Nazi art regarding women, the inherent ideology must be studied. The "new" German woman under National Socialism, was to be the mother, the model of Aryan characteristics, healthy and lean. Nazi political doctrine stated that women were inherently connected with the blood and soil of the nation, as well as nature itself. Women were to be innocent and pure, the bearers of the future Volk and the sustenance of that Volk. Once this political ideology is understood, the depiction of the German woman as mother, as nature, as sexual object, can be placed within Nazi historical context.

Political art provided the Nazi state, the historical legitimization the government needed. It provided the means by which the state could be visually validated, politically, and historically. 
THE POLITICS OF NAZI ART:

THE PORTRAYAL OF WOMEN IN NAZI PAINTING

by

JENNIFER ANNE MILLER

A thesis submitted in partial fullfillment of the requirements for the degree of

MASTER OF ARTS

in

HISTORY

Portland State University

1996 


\section{CONTENTS}

I. Introduction. . . . . . . . . . . . . . . . 1

Sources and Methodology. . . . . . . 2

Women under the Reich.. . . . . . . .4

Art and Society... . . . . . . . . .

II. Art and National Socialism.. . . . . . . . .11

The Revolt against the Modern. .. . . . 12

The "Problem" of German Art Criticism.. 21

The Nazification of the German Artist.. 25

The Art of the Eternal. . . . . . . .36

III. Kinder, Kirche, Kürche, The Politicized

Role of the German Woman.. . . . . . .49

The Cradle. .. . . . . . . . . . . . . .49

To be "Authentic and German". .. . . . .62

"Das Mädel"............ . . 68

IV. Imagery: Politicizing the Unpolitical. . . .75

Divine Motherhood.. . . . . . . 76

Blut und Boden. ........... . 86

"Natürlich". . . . . . . . . . . . 89

"Gretchen" . . . . . . . . . . . . . . . . . . . 91

Woman-Child........... . . . . . . . . 97

V. Conclusion.. . . . . . . . . . . . . . 101

VI. Bibliography. . . . . . . . . . . .107

VII. Appendix. • . . . . . . . . . . . . . . . . . . . . . .

VIII.Sources of Art. . . . . . . . . . . .114

IX. Paintings. . . . . . . . . . . . . . 117 


\section{CHAPTER 1}

\section{Introduction}

"Fascism is the aestheticizing of politics."1

Walter Benjamin 1968

Ideology is inherently contextualized within Nazi art. In fact, under the Third Reich, ideology was to function as art. Art was used by the Nazis to express the glorious union of the vollkisch nation, the love for Nazi vanguard, the newly designated roles for men and women, and above all, political art was used to underscore the importance of the Nazi racial state. The German woman was to play a very large role in the propagation of the racial state as well. Under the Nazis, art would time and time again, represent the new, pure German woman under National Socialism. Within the art itself, her place within the Reich, her contribution to the racial state, her role as the proper German woman, would be represented in Nazi painting.

Within this study, we will discover the political impetus behind Nazi art, and its connection with Nazi

'Quote from Walter Benjamin's "The Work of Art in the Age of Mechanical Reproduction," in Illuminations, edited and with an introduction by Hannah Arendt. Translated by Harry Zohn. (New York, 1968). Found in Peter Adam's Art of the Third Reich. (New York:Harry $N$. Abrams, Inc., Publishers, 1992),p.21. 
views of women. Ultimately we shall understand the links between ideology and art under National Socialism, by evaluating the actual depiction of the German woman, and the inherent ideology within the painting itself.

\section{Sources and Methodology}

Much of the histories written on the subject of Nazi art are repetitive in their research which is problematic. Until recently, histories of Germany have been centered around political, diplomatic, domestic, and economic politics. Its has only been within the last ten to fifteen years, that historians have begun to focus on social and cultural aspects of life under National Socialism. Written works completely devoted to the subject of Nazi art total about six or so. Nonetheless, the information exists, however tangled amongst other forms of Nazi political history and secondary resources.

One's research can not be complete without the study of Berthold Hinz's Art in the Third Reich, and Peter Adam's Art of the Third Reich. These two books offer a detailed, cohesive history of art under the Nazis. Both works highlight the politics within the German art world, and the depiction of the art itself. 
Hinz dives deeply into the study of one painting in particular which has been used many times over, to articulate the ideology concerning women. His study of The Judgement of Paris, proves vital in the understanding of ideology in official art. Adam provides necessary information, uncovering the fate of official art after the Allies storm Berlin in 1945. Much of the art was destroyed, however, Adam discusses the confiscation of the art after the war, and where it was held under lock and key for many years after. Art and Power, Europe under the Dictator's 19301945, a compilation, provides a useful generalized study of art under the European dictator's from 1930-1945. The work focuses on the development of a political aesthetic in Nazi Germany. This compilation did provide a few primary resources, one in particular, is a speech made by Hitler at the opening of the Great German Art Exhibit of 1937. This primary source was invaluable in understanding Nazi cultural ideology and policy. Mein Kampf proved useful in the understanding of Nazi ideology, and the crux of Hitler's cultural beliefs. A source which no student of German history should be with out is the compilation of Hitler's speeches, translated by Norman H. Baynes. Other works providing necessary 
primary documents were George I. Mosse's Nazi Culture, J. Noakes, and G. Pridam editors, Nazism Vol.1, as well as Dieter Kuntz and Benjamin Sax's Inside Hitler's Germany. These works provided documental evidence of art under the Reich, which otherwise were unavailable. The study of The New York Times perhaps was the most interesting of primary resources. Newspapers from 1937 detailing the changes of Nazi official art, its ideology, and the dissemination of official art, provided an interesting look into the past. Much of the resources have not been found in other published secondary sources. The primary resources listed above did prove vital in the creation of a cohesive history, combining ideology, and art.

\section{Women Onder the Reich}

This study combines two elements of National Socialism, ideology expressed through art and the creation of the new German woman. Because of this, it was necessary to research the underlying thematic dogma surrounding women under the Reich. Women have often been portrayed as the fervorant followers of Adolf Hitler, or as the quiet Hausfrau relegated to her realm of domesticity. Much of the female population of 
Germany would not be classified under either of these two categories, however this is how the Nazi chose to represent the German woman. More and more, as new information is uncovered, and historians take an active approach to the research, the history of women under the Third Reich becomes more complete. Thanks to historians such as Claudia Koonz, who wrote, Mothers in the Fatherland, and Jill Stephenson's Women in Nazi Society, a detailed analysis of women living under the Reich, can now be easily accessed. Ramona M. Rose, compiled excerpts from the English speaking press, into a detailed work titled The Position and Treatment of Women in Nazi Germany. This in itself is a very interesting work, for it highlights the different reactions of women in regards to Nazi policy, in and outside of the Reich. This piece offered a good account of the daily attitudes held by women towards the Reich.

There are few works actually detailing the ideology regarding women and connecting it with the pictorial representation. Although very few in numbers, the works which were available were in fact quite helpful. Mary McNichols-Webb's dissertation Art as Propaganda, concentrated on the imagery and roles of women depicted in German Expressionism, Italian Futurism, and National 
Socialism. McNichols-Webb provides a detailed connection between Nazi art and its themes of the erotic, inherent in ideology regarding women. Nancy Vedder-Schults' Motherhood for the Fatherland, highlighted the portrayal of the German mother in Nazi propaganda and political platform. This dissertation, as well as McNichols-Webb's piece, parallel the dogma and art. They also provided key primary documents, excerpts of interviews as well as speeches concerning women under the Reich, that are not found in other secondary sources. Hermann Glaser's, The Cultural Roots of National Socialism, was an invaluable source aiding the understanding and the importance of the caricature of the German maiden, her status in society, as well as her traditional literary and historical relevance. Glaser also does a fine job tracing the history of the German maiden. Glaser provided a detailed analysis, tracing the "Gretchen" figure throughout German cultural and social tradition, from her birth in Goethe's Faust to her depiction in Nazi art.

The organization of this information into a cohesive narrative is problematic considering the complexity of the subject at hand. Nonetheless, the task of the paper is to understand the complexity of the 
pictorial representation of the German woman under the Third Reich. However, to understand the contextual relevance of women in Nazi art, there first must be an understanding of Nazi political dogma regarding women, as was discussed. We must understand that her role and her status within German society was in fact entirely dependent upon Nazi dogma. The actual paintings themselves are not merely German maidens frolicking through the greater German landscape, they are much more. Because Nazi politics made up the contextual relevance within the art itself, it is imperative that women's role within German society be discussed.

Woman's role within Nazi society must be placed within a larger thematic context. An overall chapter regarding the politics of Nazi art, and the turmoil within the German art world experienced after 1933, provides the larger setting. Therefore, the image of women in art will provide an exemplary function for Nazi political art in general.

\section{Art and society}

The study of National Socialist art proves a weary task. This is primarily do to the fact that most art historians have simply refused to study Nazi art, 
deeming it non-art, and not worthy of study as Adam notes. ${ }^{2}$ Adam's also discusses that the general assumption made by art historians is that the art was so bad, it did not deserve the attention of academic study. ${ }^{3}$ Because of this, there is simply not enough known about the art of the Third Reich.

Few people have actually seen Nazi art, for much of the work was lost in bombings, or destroyed after the Allies entered Berlin in 1945. Most of the official German art was in fact shipped to the United States, where the most inflammatory works, such as Nazi war art, were kept vaulted away in Washington, under the watch of the U.S. Army. However, at present day, most of the various works have been returned to Germany, once more to be hidden from the general public, not to arouse any pro-Nazi sentiment. Under the charge of the German Minister of Finance, only "professional" researchers and historians have access to them. There is in fact a hand written catalogue of works remaining, yet it is carefully guarded, and kept out of sight. Thus the ownership and dates of the paintings are hard to come by, and it seems as if those who had owned such art work

\footnotetext{
${ }^{2}$ Found in Adam, p. 7.
}

${ }^{3}$ Ibid., p. 7 . 
are not eagerly awaiting their return, nor are they making any efforts to claim the art. Ultimately, art of the Third Reich goes unclaimed, uncared for by German museums, and largely ignored.

Main questions regarding the methodological means of research, have been relegated between the differentiation of art and history. Does Nazi art function as historical documents or as art. Perhaps to answer this question the function of art needs to be explored.

Art in general must be studied within the context of the society in which it was created, because art functions symbiotically. First, art reflects or mirrors much of the societal characteristics in which it was created. For example, the explosion of Expressionism as an art form before and after The Great War, did mirror the new found freedoms of western society, the reevaluation of traditional social mores, and political upheaval experienced throughout most western European societies. At the same time, art represents the wants and desires of the artist or in the case of the European totalitarian regimes, such as Soviet Russia and Fascist Italy, governmental ideology and idealism. Therefore, art reflects and represents the society in which it was 
created.

In fact Nazi art can not be studied from outside the context of its creation, outside the context of Nazi society itself. This is because the ideology of the Third Reich is expressed contextually throughout the paintings themselves. If the true definition of art is that which reflects and represents, then in fact National Socialist art can be considered true art, and worthy of study. Nazi political art can be considered both historical documents and art. Nazi art reflects much of the inherent disarray of Nazi society while contextually representing Nazi political dogma.

Understanding the subject matter of Nazi art must first begin, as discussed before, with the understanding of the politics within the german art world itself, what the Nazis believed art to be. Once understanding the twists and turns of the ideology itself regarding the woman's place under the Reich, then perhaps one can view the actual depictions of women within Nazi art, in a different light. 
CHAPTER 2

Art and National Socialism

Art that is in our blood, art that people can comprehend, because only the art that the simple man can understand is true art."

The Hakenkreuzbanner, June 10, 1938

Within the realm of politics one must classify Nazi art, art commissioned by the government of the Third Reich. The commitment the National Socialists had to the arts is in fact great, when we consider the brutal physical violence perpetrated by the state, and its fixation with action and great deeds. Nonetheless, the Nazis went to great lengths to turn the German art world upside down in the name of "beauty." Key National Socialist concepts such as strength, Blut und Boden, the spirit and essence, the racial ideal, would all be elements of this Nazi definition of "beauty." ${ }^{5}$ This aesthetic expressed the values of traditional German militarism, as many historians have written, and the Nazi racial state. ${ }^{6}$ Nazi political art exemplified

${ }^{4}$ Comments from the National Socialist Newspaper The Hakenkreuzbanner, on the opening of the first "Great German Art Exhibition" in 1937. Found in Adam, p.94. ${ }^{5}$ The ideal of Nazi beauty is sometimes defined as "strength and beauty." This catch phrase encompasses the Nazi aesthetic.

${ }^{6}$ Historians such as Hermann Glaser have connected the Nazi art fervor with the "Prussian fighting spirit." 
National Socialist platform and legitimized the Nazi political dynamic.

\section{The Revolt against the Modern}

To understand what Hitler and the Nazis believed "true" Germanic art to be, we must first discern what it was not. Art was never to represent that which was seen as modern. The "modern" supposedly expressed the chaotic city, steel, concrete, and darkness. These supposed characteristics of modern art were assumed to be "un-German." Modern art was to be inherently "Jewish," "Bolshevik," and "feminist." While the terms were interchangeable, this modern representation of German life was labeled "degenerate" by National Socialist ideologes.

The Modern art scene broke like a flood in the 1920's. Many Germans found its abstraction and iconoclasm incomprehensible and irritating and supported Nazi denunciations of it. The Nazis believed modern art to be a type of villainy, something foreign. It represented the sell out of German culture to decadence and supposed spiritual degradation. ${ }^{7}$ Modern art was the

${ }^{7}$ Hitler ultimately believed degradation of the German race came with the influences of the modern world. The supposed "true" spiritual characteristics of the Germans 
saboteur of true Germanic art. Hitler himself believed modern art represented the cosmopolitan with its "corruption and greed." However, this sentiment was held early on by Hitler, and had been quite blatant in Mein Kampf. Hitler stated that modern art:
was the villain; it stood for decadence and internationalism, jewishness, homosexuality, bolshevism, big city capitalism. So long as the characteristic features of the cities of our day, the outstanding points that catch our eyes are whore houses, bazaars, hotels, offices in the form of sky scrapers, etc., there can be no talk of art or any real culture. ${ }^{8}$

Hitler made sure he connected modern art with the crassness of modern society. Each of these labels given modern art were to inflame the public. This was done to rally the population behind Nazi cultural policy, and cause the nation to revolt against which was seen as "degenerate." In 1928 Hitler referred to modern art as a sham, a lie;

what we experience today is the capitulation of the intellectual bourgeois to insolent Jewish composers, painters, who set miserable trash in front of our own people and have brought things to such a pass that for sheer cowardice the people no longer dare to say: That doesn't suit us, away with this garbage. No, against their better knowledge and conviction the so-called intellectuals in our nation accept as beautiful something set before them by those people, which they

had lost to the "foreign" influences of the metropolitan city.

${ }^{8}$ Adolf Hitler Mein Kampf (Boston: Houghton Mifflin Company, 1943) ,p.397. 
themselves must automatically feel to be ugly. That is a sign of our universal decay, a cowardice that can be thrown to the ground with one slogan: you are a philistine. ${ }^{9}$

Again, Hitler calls for the unification of the German people against modernity. Hitler believed the German people had almost been beguiled by modern art, sucked into the acceptance of modern culture, by the fashionable context of the art itself. Hitler discussed the subjects of modern art calling them misformed cripples and cretins;
women who inspire only disgust, men who are more like wild beasts, children who, were they alive, must be regarded as under God's curse. And let no one tell me that this is how these artists see things... that therefore really men who on principle feel meadows to be blue, the heaven green, clouds sulfur-yellow or, as perhaps they prefer to say, 'experience' them thus. I need not ask whether they really do see or feel things in this way, but in the name of the German people I have only to prevent these miserable unfortunates, who clearly suffer from defects of vision, attempting with violence to persuade contemporaries by their chatter that these faults of observation are indeed realities or from presenting them as 'art."10

The National Socialists did believe that modern art was to be by necessity, a short-lived phenomenon, because it was connected with the international art

'Quoted in Konrad Heiden, Der Fuehrer, Hitler's Rise to Power (Boston: Houghton Mifflin Company, 1944), p.365366.

${ }^{10}$ Norman H. Baynes translator The Speeches of Adolf Hitler (New York: Gordon Press, 1981), Vol. 1, pp.589-92. 
scene. Modern art was said to be a fad and in the "grip" of the "shadowy art dealer" on 18 July 1937 Hitler delivered a speech at the opening of the House of German Art in Munich. He said the previous art waves of "foreign" influence were to evoke:

An international experience, all comprehension of its intimate association with a people was stifled; it was said that there was no such thing as the art of a people or, better, of a race; there was only art of a certain period.... Art is a time-conditioned phenomenon. So today there is not a German or a French art, but a modern art. This is to reduce art to the level of fashion in dress, with the motto 'Every year something fresh."11

With this speech the onslaught to create a new German art would begin. However, any art representing the foreign or modern was to be eradicated. Hitler's tone soon changed while referring to modern art from annoyance to the threatening. More and more, Hitler was to hold those responsible for the creation of "degenerate" culture, accountable. At the dedication of the House of German Art in 1937, Hitler warned those creating these horrific works of art:

all those taking part in such pollution do not want to forget that sooner or later the hour

${ }^{11}$ From The Speeches of Adolf Hitler, April 1922-August 1939, translated by Norman H. Baynes. Oxford: Oxford University press, 1942), Vol.1,pp.584-592. Found in George Mosse's Nazi Culture. (New York: Grossett and Dunlap, 1966), p.11. 
will strike for their disappearance. With the opening of this exhibition has come the end of artistic lunacy and with it the artistic pollution of our people. I can promise you all that cliques of gossips, dilettantes and artistic cheats will be sought out and suppressed. ${ }^{12}$

Consequently, a campaign attacking art which represented the modern was undertaken first in 1933-34 and again in 1936-37. These two periods are important for it is within these two periods, that National Socialist ideology became solidified, creating a unified front against that which was considered "degenerate" in German society. Along with the purging of German museums, The Reich Chamber of Culture initiated the "direct attack" on private collections, in order to purge the "distasteful." On August 4, 1937, The New York Times reported:

The emphasis laid on the disregard of legal forms and property rights is taken to mean that the order affects not merely state museums, but also the hitherto independent provincial and municipal museums as well as private art foundations heretofore open to the public. Even private ownership of forbidden art becomes dangerous because it carries the suspicion of Bolshevist, or at least oppositional sentiment. ${ }^{1}$

\footnotetext{
${ }^{12}$ The New York Times. 18 July, 1937, p. 8.

${ }^{13}$ Report on the Nazi Art Purge launched by Goring. Goring ultimately places Dr. Bernhard Rust, Minister of Education for both Prussia and the Reich in charge. In fact the future of condemned art was obscure. Many German artists wanted to stage a bonfire to finally "rid
} 
A commission was formed with the authority of the Führer, to seize all modern art owned publicly or privately. Hitler appointed Professor Ziegler of Munich to lead the onslaught. Ziegler, himself an artist, had found official approval after 1933 painting nudes, and he ultimately attained the presidency of the Reich Chamber of Visual Arts in 1936. His commission composed of notables such as SS officer Count Klaus Baudissin, the racist illustrator and pamphleteer Wolfgang Willric, ${ }^{14}$ art critic for the Völkischer Beobachter Franz Hoffmann, and others were given orders to enter every German museum and confiscate all Modern art.

Their orders stated that they were to take possession of works no older than 1910, although much of what was actually seized were works dating earlier than 1910, as well as works by non-German artists. Among the paintings taken were those by Picasso, Kandisky, Matisse, Vincent Van Gogh, just to name a few.

In addition to those artists, the famed German

the scourge" except for a few examples to keep for the "sake of history" so future generations of Germans would "understand" the purge. The New York Times, 4 August, 1937.

${ }^{14}$ Wolfgang Willric as racist illustrator and pamphleteer found in Berthold Hinz, Art in the Third Reich. (New York: Pantheon Books. 1979), p.39. Translated by Robert and Rita Kimber. 
expressionist Emile Nolde, had been a member of the Nazi party as early as $1920 .{ }^{15}$ Both Nolde and Edvard Munch had embraced the new Regime like many other modernists of the time. However, many believed that the confiscation of their work was merely a "phase" of the new government. Most modernists, including Kandisky, believed that Alfred Rosenberg, leading Party ideologist, would allow modernists to display their work in Germany, they just simply had to wait until the fervor had ended.

Nonetheless, the total number of works confiscated within these two periods is estimated at $15,997 .{ }^{16}$ The campaign against "degenerate" art took works from almost 1,400 artists in all. ${ }^{17}$ Works by 112 blacklisted artists were chosen to be displayed in the 1937 "Exhibition of Degenerate Art."18 Each piece was categorized and given one of the following captions.

Group 1: "A barbarous method of representation." Group 2: "Hocus Pocus, works by Emile Nolde." Group 3: "offer conclusive proof of the political

${ }^{15}$ Emile Nolde, member of the Nazi party found in Adam, p. 60.

${ }^{16} \mathrm{~F}$. Roh (1962), Catalog Entartete Kunst (Munich, 1962), pp. 122ff. Berthold Hinz, Art in the Third Reich. Translated from German by Robert and Rita Kimber (New York: Pantheon Books, 1979), p.39.

${ }^{17}$ Ibid., p. 40 .

${ }^{18}$ Ibid., p. 40. 
origins of degeneracy in art. Art is used to preach political anarchy."

Group 4: "Art as a tool of Marxist propaganda." Group 5: "The whole world appears to be one huge whorehouse, and humanity is made up of nothing but prostitutes and pimps...."

Group 6: "The systematic eradication of every last trace of racial consciousness."

Group 7: "That what is used to call itself modern."

Group 8: "Representative selection from the endless supply of Jewish trash...."

Group 9: "Total madness, height of degeneracy."19

Ultimately over 2,000,000 people passed through the exhibit in the old gallery at the Hofgarten Arcades.

In an attack on modern art reported in The New York

Times, Propaganda Minister Goebbels declared that everything aesthetic in Germany had been "oppressed" by the "tyranny of Jewish art." 20

No wonder our art was regarded as insane during those dark years. We experienced a diseased period with disgusting symptoms in the shape of these horrible specimens of so- called art found in our museums and galleries. ${ }^{21}$

The confiscation of all modern art work was to function as an example. Those artists and university faculty who did not rally behind Nazi art dogma would be made an example of. Hitler commented on the Exhibition of Degenerate Art:

These masters felt themselves to be Germans, and consequently they created works which should be

${ }^{19}$ Ibid., p. 40-41.

${ }^{20}$ The New York Times. 17 June 1937,p. 7.

${ }^{21}$ Ibid., p. 7 . 
valued as long as there should Germans to appreciate them. But these modern works we would also preserve a documents illustrating the depths of that decline into which the people had fallen. The exhibition of the "Art of Decline" is intended as a useful lesson. ${ }^{22}$

The exhibition of modern art proved useful propaganda against what Hitler termed "Art of Decline," and against the existing German art world. Hitler finished his speech with a clear message that it was now the duty of the Reich to raise German culture to its pinnacle.

I know however, that the new Reich will call into being an astounding blossoming of German art. For never has art been presented with greater duties and opportunities than this Reich. Never before has more generous support been measured out than in National Socialist Germany. ${ }^{23}$

Modern art was out of the way, Modern artists had either bent to Nazi art policy or left the country. Many did stay, unable to work in Germany until after W.W.II. With the outlawing of modern art in 1936, the government of Nazi Germany made sure the creation of true German art would be unhindered. The Reich would enjoy a total monopoly over each artistic endeavor made within the German art world.

${ }^{22}$ Ibid., p. 588

${ }^{23}$ Ibid., p. 8. 


\section{The "Problem" of German Art Criticism}

The thwarting of any form of professional art criticism aided the nazification of German art. Goebbels had explained that the people had never taken part in art criticism. ${ }^{24}$ The Reich would now ensure that if art was created for the people, the public itself should function as the critic. Nazi art was to be the pictorial representation of German society and only the Volk would judge its validity and the value of its artistic representation. The artist was to create for the people and through his work, he was held accountable to the people. On 11 September 1935 Hitler delivered an address on art criticism.

To this activity of ours [art criticism] at such a time two objectives have been raised. I need not concern myself with the opinion of those hypocrites who, although they realize the permanent significance of our cultural plans, through their hatred of the German people cannot lose any opportunity for criticism. Their rejection of our actions is its highest recommendation. ${ }^{25}$

His speech continued to argue that critics of all kinds deplore the art of true genius. "True art" would have the people on its side. Art was to speak directly

\footnotetext{
${ }^{24}$ K.F. Schrieber (1937), V,pp.26f. Berthold Hinz, Art in the Third Reich. (New york, Pantheon Books, 1979), p.37. Translated from German by Robert and Rita Kimber.

${ }^{25}$ Ibid., p. 570 .
} 
to the people, completely unmediated. This would lead to the creation of a "new" German art, and was to lead to a positive cultural revolution, inspiring German cultural and political dominance. Hitler stated in 1937 that the state must thwart art criticism for the generations of Germany will judge the competence of Nazi art.

Captain Wilhelm Weiss, head of the Reich Press League commented for The New York Times in March of 1937:

If a work of art and its presentation contain a National Socialist idea we favor it, if the opposite is the case, we have not only the right but the duty to be against it. Art criticism is not primarily an aesthetic question, but a political one. ${ }^{26}$

Captain Weiss stated that everyone must understand the demands and functions of a totalitarian state. What censorship is practiced over the press should also be extended to cultural matters under the Reich as well. Nazi officials also believed that the creation of true German art would be eased with the metamorphosis of art criticism into the Nazi idea of "editing." The

${ }^{26}$ Captain Wilhelm Weiss, head of the Reich Press League and chief deputy to Minister Goebbels, announces the changes in cultural policy in an address to the Central German Press Chambers at Dessau. Quoted in The New York Times, 16 March, 1937,p.15. 
plans for the creation of true German art would not come to a halt. The German artist would not be hindered by any means, the ideological context within the art itself was not to be questioned. The government would provide the means to keeping the channels between the people and the artist unhindered by nay sayer's, critics, or any persons who did not understand the Nazi cultural revolution.

Cultural policy would be taken out of the hands of the independent critic. The art of the Reich would now be commissioned and sanctioned through official channels only. Hitler had in fact cut off all discussion effectively with the "Decree concerning art criticism" which was issued on November $11,1936 .{ }^{27}$ Goebbels commented:

I granted German critics four years after our assumption of power to adopt themselves to National Socialist principles.... Since the year 1936 has passed without any satisfactory improvement in art criticism, I am herewith forbidding, from this day on, the conduct of art criticism as it has been practiced to date. From today on, the art report will replace art criticism, which, during the period of Jewish domination of art, totally violated the meaning of the concept of 'criticism' and assumed the role of judging art. The art critic will be

\footnotetext{
${ }^{27}$ K. F. Schrieber (1937), V, pp. 26f. Berthold Hinz, Art in the Third Reich (New York, Pantheon Books, 1979),p.37. Translated from German by Robert and Rita Kimber.
} 
replaced by the art editor. ${ }^{28}$

Art criticism became positive validation only. Instead of evaluating the cultural meaning of a painting, the art editor would simply comment on colors used, the message the piece conveyed, and the "spiritual" edification the painting evoked. Or rather, how a painting captured the "true" German spirit, there was to be absolutely no debate.

The New York Times commented on the order issued by the Propaganda Ministry to prohibit art critics from criticizing Nazi commissioned art work. The art critic under the new Reich must devote himself to the description of the new art only. The March 17, 1937 edition sarcastically stated:

Now we have Propaganda Ministry ukase no. fz879065, or there abouts, ordering critics to resume criticizing. Since the critics may have grown a bit rusty in the exercise of taste and discrimination, the Propaganda Ministry tries to make things easy for them. If a work is proNazi it is good art. If it is anti or neutral, the critic is instructed to find himself at a loss for words to describe how bad it is." 29

Goebbels efforts to thwart art criticism was just another means to exercise total control over German art. Therefore the art report would be less an "evaluation"

${ }^{28}$ Ibid. , p. 37.

${ }^{29}$ The New York Times, 17 March, 1937, p. 24. 
than a description and appreciation. The duty of the art editor was merely to appreciate that which the Reich labeled as "worthy" art.

The art report would be signed with the author's full name, Reich officials would in fact hold the editor responsible for its content. ${ }^{30}$ These professional regulations would require special approval for the position of the art editor and it would be made on the "assurance" that the art editor had received proper "training."

This was just another aspect of Nazi control over the institution of German art. With the mandate against art criticism, a platform defining the composition of "Germanic" art, and with the extensive campaign to rid Germany of all "modern influences," the Nazis then turned to "purify" the role of the artist and his relation to society.

\section{The Nazification of the German Artist}

As discussed, the National Socialists used art as an aesthetic means of support for Nazi dogma and policies. The political rallies, the song handbooks, the party members' uniforms, the arm bands, all helped ${ }^{30} \mathrm{Hinz}, \mathrm{p} .37$. 
create the collective Nazi aesthetic. The politicization or nazification of German art went hand in hand with the nazification of German artists. It would be the "new" artist of the Nazi state who would function as an important bridge between the people and the government, between National Socialist ideology and the masses.

Many artists of the time, opposed to modern art, found a niche with the Nazi party. Many of these painters worked within the realm of realism, or realistic painting. These artists chose to paint the world in its "natural" state. It is true that artist such as Paul Mathias Padua, who painted a famous rendition of "Leda and the Swan" on government commission, or Fritz Mackensen, known for various depictions of the "new" German mother, were not able to find their place within the international market of the time. Opportunist artists such as Padua and Mackensen who would find their creative endeavors appreciated by Hitler and other Nazis officials.

The artistic war between representational art and abstract art would in fact become a political battle. Many Nazi officials and artists alike believed that the war on art was purely a debate on aesthetics. However, 
many of the artists who had experienced success, who had established careers in the art world before the Great War, now saw themselves as the guardians of "true" Germanic culture, and eagerly joined the Nazi cause.

The Nazis were able to prosper on the anti-Jewish sentiments which infiltrated the German art world. However this anti-Jewish fervor was firmly in place amongst the traditionalist painter's of Germany long before Hitler came to power in 1933. Painter Bettina Feistl-Rohmeder, formed an art group called the Deutsche Kunstgesellschaft or German Art Society. Only artists of German blood could be counted among groups members. The German Romantics were their models, and works by modern artists such as Gauguin and Matisse were labeled non art. ${ }^{31}$ More and More, there was a call for the creation of an "heroic" German art. The Nazis, while embracing and celebrating these sentiments inspired many artists to stay and join the Party, supporting Nazi racial ideology. Architect Julius Schulte-Frohlinde supported the party for its anti-Semitism,

The Jewish influence on the general public was disastrous. Newspapers, architectural books, and magazines are contaminated by the spirit. They confused those who wanted good things. The inventors of soulless international fashions are

${ }^{31}$ Found in Adam, p. 32. 
the Jews and Marxists, who could not and will never understand the German soul. ${ }^{32}$

Such views provided the Party with powerful propaganda against the pre-1933 art establishment. It would be the middle class who patronized traditional artists, and who also supported Nazi racial doctrine. It would be the middle class from which Hitler drew much of his support and it would be the middle class who supported the arts. Hitler promised them he would bring back the simple romanticism of past German culture, and because of this, political motives connected with intensely felt aesthetic concepts would mark the art policy of the Third Reich. ${ }^{33}$ The conservative, educated middle-class played right into the hands of the Party with promises of a "heroic" German art. ${ }^{34}$

The organization of all professional artists into The Reich Chamber of Culture meant total control of all artistic endeavors. Once "cleansed" of "undesirable" artists, the rank and file of the Reich Chamber were flooded with those waiting happily to do Hitler's bidding. The willingness of such artists absolutely

${ }^{32}$ Julius Schulte-Frohlinde, "Baukultur im Dritten Reich," (Bauten der Bewegung 1939) Vol. 1, p. Iv. Peter Adam, Art of The Third Reich (New York: Harry N. Abrams, Inc., 1992), p.39.

${ }^{33}$ Adam, p. 43.

${ }^{34}$ Adam, p. 39. 
guaranteed that the state would have total control over work displayed in galleries and museums. This would also assure that artists would be "obliged" to serve the state's ideology.

Joseph Goebbels had stressed that the Reich was to "breed a new type of artist." ${ }^{35}$ The aim of The Reich Chamber of Culture was to organize the arts in military fashion. It was important that the artist understood his function, and that function was service to the state. The artist was now a civil servant, and perhaps the final stage in cementing the artist to the state was in fact the elimination of distinction between poet and soldier. For all intents and purposes, the artist would fight for German culture. Reich Theatrical Controller Rainer Schlösser stated:

Not here poet and thinker, there soldier and politician, but proud brows beneath steel helmets, high hearts in armor, and when the time comes to fight, German souls in the trenches. ${ }^{36}$

The artist would be an educator, the artist was to live amongst the people, to participate in the life of the people. National Socialist artists were to create art

${ }^{35}$ Joachim C. Fest. The Face of the Third Reich (New York: Pantheon Books, 1970), p.256.

${ }^{36}$ Rainer Schlösser (Wille und Mach) No. 3, 1943. Joachim C. Fest The Face of the Third Reich (New York: Pantheon Books, 1970), p.256. 
which would serve an idea, the state, the community, and above all Nazi political ideology.

Hitler plainly stated that the artist does not simply create for the sake of the artist, but for the people and is inspired by the people. The subject of "true" art was to ultimately stem from the masses and if an art relied on "small cliques" for sustenance it would be considered "intolerable" to the people and the state. "Such an art only tries to confuse instead of gladly reinforcing the healthy instinct of the people, "37 Hitler stated.

Art was used unite Hitler with the nation aesthetically, while expressing Party dogma and governmental policy. Hitler discussed the importance of visual art and the resurrection of German culture, as well as the criterion for the "true" Nazi artist:

We believe that especially today, when in so many spheres the highest individual achievements are being manifested in art also the highest value of personality will once again assert itself. ${ }^{38}$

Hitler concluded his speech at the dedication of the House of German Art in 1937. He stated that the state, although he uses the term (We), was more interested in

${ }^{37}$ Ibid. , pp . 589-92.

${ }^{38}$ Ibid. , pp . 589-92. 
ability of an artist than his artistic intent. The intent was that of the people and it was to be selfevident.

They need to be told that art does not create a new age, that it is the general life of peoples which fashions itself anew and therefore often seeks to express itself anew. . . ${ }^{39}$

The Party surely believed that art for art's sake would only create an unwanted schism between the artist and the people. It is a two-fold problem for Hitler, on one hand, the artist's work must depict "realistic" German reality, yet it was the responsibility of the German people to revive an historical instinct which would be worthy of visual expression. Therefore the task of the artist and the role of the German people were to go hand in hand, and only through their unification would the artist be able to produce "true" German art. The Blaue Reiter Almanac published that:

The tremendous difference between the artist today and the artist used to be part of an entire people with its own set of values and its own religion.... But nowadays, dilution, discarding, and destruction of old ideals. That explains the bewildering array of artistic trends and the desperate search for standards. It is surprising that the artist of today withdraws into himself? Thus necessity attains what artists in better times earnestly aspired

\footnotetext{
${ }^{39}$ From the Völkischer Beobachter, July 19, 1937, Translated by Dieter Kuntz Inside Hitler's Germany (Lexington, Mass; D.C. Heath and Company, 1992), p.230.
} 
toward: introspection. It seems to me that this acquisition of self-knowledge provided the best justification for any artist's making himself a center and focal point; if every artist strove with utmost integrity for selfknowledge, the true source of our energy, all the many centers together would yield the whole. ${ }^{40}$

The artist was to be a soldier waging his own battle in the German art world. He was to wage a battle against cultural modernity and the "degradation of the German soul." "A new epoch is not created by the Littérateurs but by fighters, those who really fashion and lead peoples, make history."41 Great art in Hitler's mind would be created through "the struggle"the struggle on behalf of the artist no less. Artists such as Karl Alexander Fügel and Rudolph Hermann Eisenmenger, whose depiction of the German as a solider would help piece together the "grand" illusion the Nazis wanted portrayed.

The treatment artists received who were especially close to the Führer was astounding. Their lives of

${ }^{40}$ The Blaue Reiter Almanac, edited by Klaus Lankheit (New York: Viking, 1974), pp. 55-71, part of letter dated 1918 May -- appears in The Letters and Diaries of oskar Schlemmer, edited by Tut schlemmer and translated by Krishna Winston (Middletown, Conn: Wesleyan University Press, 1972), p. 50., found in Henry Grosshans, Hitler and the Artists (New York: Holmes and Meier Publishers, Inc., 1983), P.28.

${ }^{41}$ Ibid. , p. 589 . 
luxury were paved by the government. Henri Bouchard, a French sculptor, remarked on his return from a visit to Germany:

The German state wants the well being of the artist. He shall no longer suffer from the critics.... The care of the state also extends to his personal life. Well known artists and sculptors like Arno Breker in Berlin and Thorak in Munich have been given large studios in order to fulfill state commissions for monuments which represent a gigantic and heroic humanity.... In this way a great country honors its artists and their work, its intellectual culture and the dignity of human existence. It has recognized the value of art as a historical necessity." ${ }^{42}$

The New York Times reported an announcement by Goebbels on June 14th, 1937. Old-age pensions would be given to all "deserving" ${ }^{43}$ German artists and were to be instituted by the National Socialist government. 2,000,000 Marks were set aside for theatrical professionals alone. ${ }^{44}$ Provisions for retired film artists, painters, and sculptors would likewise be made soon after. Goebbels had remarked that this government was willing to "protect" its creative artists like no other government had done in the past. Hitler added to this, he had stated that he wanted his artists to be

${ }^{42}$ Bouchard, in Illustration, (Feb. 7, 1942. Peter Adam, Art in the Third Reich (New York: Harry N. Abrams, Inc., Publishers, 1992), P.202.

${ }^{43}$ The New York Times, 15 June, 1937, p.15.

${ }^{44}$ Ibid., p.15. 
treated like princes, and they were.

Albert speer, famed architect of the Reich was given huge sums of money towards the creation of his private studios or Statsateliers. Painters such as Adolf Wissel and Constantin Gerhardinger were given minted medals granting them honorary professorships. Some artists received large sums of money, automobiles, and ritzy apartments confiscated from Jewish citizens. Grand amounts of money would be pumped into the state's art budget, it would come from the marketing of special collective stamps, royalties from Mein Kampf, as well as confiscated Jewish property. ${ }^{45}$

However, this type of governmental "protection" came at a very high price. The limits placed on artist were justified by the "nature" of the struggle for German cultural dominance. These limits mirrored the political arena as well. Hitler had compared the resentment felt by those who were against the Nazi political revolution to the attacks experienced in the German art. This only increased Hitler's vigor to "cleanse" the world of German art. Therefore the artist expressed the political and was supported by the political, protected by the political. In Hitler's

${ }^{45}$ Adam, p. 117. 
speech at the opening of the Third Exhibition of German Art in July 1939, he stated:

Individual outstanding artists might turn their thoughts to experiences, the events and the fundamental ideals of the present. For however numerous in their thousand fold variety may be the historical visions or the other impressions which life may make upon the artist and which enrich him for his creative work, which rise before his mind and awake his enthusiasm, yet over and above them all stands the present day splendour of his own time which need not for comparison with the grandest epochs in our German history. ${ }^{46}$

It would in fact be the artist's task not simply to depict the essence of the German people in a traditional form, "channeling" the innate "virtue" of the people. For all intents and purposes, the impetus behind the artist creation would be the political, and moreover, the artist would be a chosen individual destined to relate governmental policy and ideology to the nation, and without any form of public art criticism, the creation of Nazi political art went unchallenged.

Artists were no longer viewed as a single, individual entity separate from the Volk. They were a members of the German community, and together would embark on this creative effort. Art was to be "the leading expression of the essence of the community,

\footnotetext{
${ }^{46}$ Baynes, p. 608 .
} 
pervading it through and through calling out the true values of the individual and infusing them with the goals of the Volkgemeinschaft." 47 Modern art was outlawed, art criticism was thwarted for art editing, the German artist was kept under the "protection" of the Reich, all in the name and the creation of the new German art. The cultural uplift of Germany would be at hand.

\section{Art of the Eternal}

There would be many battles over aesthetics of the Third Reich. The debate over the relationship between art and politics would in fact be central. Nazi officials, intellectuals, and artists alike called for the restoration of heroism, or the notion of the great struggle to be restored to German life, politics, and culture. "Art and politics" and "German art as the proudest justification of the German People," were just a couple well-known examples of verbiage dedicated to the cultural uplift of Germany. ${ }^{48}$ In 1935, Hitler remarked that a people does not live longer than the

${ }^{47}$ Benjamin Sax and Dieter Kuntz. Inside Hitler's Germany (Lexington, MA: D.C. Heath and Company, 1992), p.219. ${ }^{48}$ Verbiage in quotations found in Henry Grosshans, Hitler and the Artists. (New York: Holmes and Meier Publishers, Inc., 1983), p.10. 
evidence of its civilization. The "new" German art would be the pictorial representation of the unity of Germania- the Volkgemeinshaft, politically and culturally. The new art would provide for future generations of Germans, the needed proof of Nazi "greatness."

Hitler held that art was a mission which demanded fanaticism. Art and politics were inherently linked. The fervor exhibited in the realm of politics would be connected with that which was felt in the art world and vice-versa. A healthy, vigorous politics would mirror an equally healthy and vigorous art. Moreover, the battle for German politics and the struggle for cultural dominance would go hand in hand. On March 23, 1933, Hitler addressed the new government:

Simultaneously with this political purification of our public life, the government of the Reich will undertake a thorough moral purging of the body corporate of the nation. The entire educational system, the theatre, the cinema, and the wireless -- all of these will be sued as means to this end and valued accordingly. They must serve the eternal values present in the essential character of our people... It is the task of the art to be the expression of this determining spirit of the age. ${ }^{49}$

Hitler continued this speech articulating once again

${ }^{49}$ Norman $H$. Baynes translator, The Speeches of Adolf Hitler (New York: Gorgon Press, 1981), Vol .I, p.568. 
that it was, therefore, the task of the government to safeguard German culture, and lead Germany to its future.

In all spheres of our historical and cultural life, the knowledge of our tradition must be the pride of the present and must therefore form a bridge which shall lead us into the future. ${ }^{50}$

Joseph Goebbels, Propaganda Minister for the Reich, stated in 1933 that the Nazis needed to propagate a revolt against modernity. ${ }^{51}$ The Nazis had a "noble mission" to transform and revitalize the very Geist or spirit of the people. ${ }^{52}$ Goebbels believed that this transformation of spirit would provide the impetus behind the renewal of German culture and bridge the rift between the people and the state. In 1934 Goebbels stated that the arts:

$$
\begin{aligned}
& \text { are for the National Socialist state a public } \\
& \text { exercise: they are not only aesthetic but also } \\
& \text { moral in nature and the public interest demands } \\
& \text { not only police suppression but also guidance. }{ }^{53}
\end{aligned}
$$

The arts were no longer viewed as a single minor aspect of life of the individual. The cultural revolution would effect the Volk in its entirety, politically and artistically. The entire community would embody this

${ }^{50}$ Ibid., p. 568

${ }^{51}$ Ibid.

${ }^{52}$ Adolph Hitler from a Party Day speech, Nuremberg, September 2, 1933. Adam, p.9.

${ }^{53}$ Ibid., p.397. (RGB1 p. 661) 
creative effort. This embodied the Nazi concept of

Kultur, art was to be:

the leading expression of the essence of the community, pervading it through and through, calling art the true values of the individual and infusing them with the goals of the Volkgemeinshaft (community). ${ }^{54}$

Hitler believed that German art would proclaim the artists' faith in the ideal and the "beauty" of the Nordic would triumph heroically over the "degenerate."55 This "heroic" art would be seen as something revolutionary, a new epoch in German history for the Volkgemeinshaft, ${ }^{56}$ the community as a whole.

On 11 September 1935, Hitler delivered an address at the Nuremberg Party Conference, stating that any suspension by the government of cultural activism and creativity, would be considered dangerous to the national mind set. ${ }^{57}$ A dominant culture was to be the nation's moral strength and the cultural achievements of society were considered the highest achievements of the

${ }^{54}$ Benjamin C. Sax and Dieter Kuntz Inside Hitler's Germany (Lexington Massachusetts: D.C. Heath and Company, 1992) p. 219.

${ }^{55}$ Nordic became a key word in the National Socialist theory of art. These Nordic elements were to be inherent in the Blut of the German nation. Adam, Art of the Third Reich. (New York: Harry N. Abrams, Inc., Publishers, 1992), p.23.

${ }^{56}$ Volkgemeinshaft has been defined as the "organic community of the people."

${ }^{57}$ Baynes, p. 570 . 
life of a community. Hitler surmised that whether in spirit or material form, art embodies the essential life force of its people, ${ }^{58}$ and Nazi art would embody that Nazi ideal of the essence of the people.

For Hitler "true" art was eternal, it did not follow trends of modernity and fads, and arose "from the depths of the essential character of a people which successive generations can inherit." ${ }^{59}$ The Nazis hoped that the German people themselves would give rise to the new German art. Their national character, feelings, emotion and development would be the main spring of the "new" German culture. Hitler's wish for an art which corresponded to the homogeneity of German racial attributes was central. Those Germans with "pure" racial bodies and minds were to experience "true" German thought, emotion and logic, and therefore create "true" Germanic art. However, it was the Aryan which was identified as the creative force behind German culture. In Mein Kampf, Hitler discussed the ideals of the Aryan, the German racial ideal:

If we were to divide mankind into three groups, the founders of culture, the bearers of culture,

${ }^{58}$ Ibid., p. 570 .

${ }^{59}$ Adolf Hitler, April 1922-August 1939, translated and edited by Norman $\mathrm{H}$. Baynes (New York: Oxford University Press, 1942), Vol. I, pp.584-592. 
the destroyers of culture, only the Aryan could be considered as the representative of the first group. From him originate the foundations on walls of all human creation, and only the outward form and color are determined by the changing traits of character of the various peoples. He provides the mightiest building stones and plans for all human progress and only the execution corresponds to the nature of the varying men and races. ${ }^{60}$

Hitler maintained in Mein Kampf that it is the Aryan who is responsible for the creation of "true" culture. ${ }^{61}$ This culture was supposedly lost through what was labeled as "blood mixing" between the Aryan and other races. The Aryan supposedly gave up the purity of his blood, and lost his capacity to create true culture. However, Hitler remarked that the culture lost could be found yet again through the Aryan's renewed devotion to the racial state. The Aryan's willingness to sacrifice his individuality for the good of the collective would renew Germanic culture. Already we discover the link between art and the state:

Not in his intellectual gifts lies the source of the Aryan's capacity for creating and building culture. If he had just this alone, he could only act distinctively, in no case could he organize; for the innermost essence of all organization requires that the individual renounce putting forward his personal opinion and interests and sacrifice both in favor of a

${ }^{60}$ Adolf Hitler, Mein Kampf. Translated by Ralph Manheim (Boston: Houghton Mifflin Company, 1943), p.290.

${ }^{61}$ Ibid. , p. 293. 
larger group. ${ }^{62}$

Hitler calls this sacrifice for the state Pflichterfillung- to fulfill the commitment to the community before the self. This is the Aryan's powerful creative force. The creation of the state was the impetus behind the creation of culture. Hitler adds to this belief the notion that the Jews could have never created a culture of their own, for they never possessed a state or Boden (18th century view of the nation) with definite territorial boundaries. "Hence the Jewish people, despite all apparent intellectual qualities, is without any true culture, and especially without any culture of its own." ${ }^{63}$ We begin to understand that for Hitler, a dominate culture went hand in hand with clearly defined territorial boundaries and the creation of ethnicity within those boundaries.

The spirit of the Volk, the spirit of the people, which would inspire painters, thinkers, poets, and musicians alike. Simultaneously, this was to be the revival of German culture and German politics. They were to complement each other, and both could become stronger with the growth of the other. The sole function

${ }^{62}$ Ibid., p. 297

${ }^{63}$ Ibid. , p. 302. 
of this new art was to recapture that German character as it had supposedly existed before the rise of the modern era, and reflect the progression of the German character. Hitler stated:

They talk of primitive art, but they forget that it is not the function of art to retreat backwards from the development of people; its sole function must be to symbolize that living development. ${ }^{64}$

This cultural character was Romantic in form. On 18 July 1937, Hitler opened the House of German Art in Munich. Referring to the destruction of the Glass Palace museum which had burned down on 6 June 1931, Hitler stated that much of the treasured "pure" German art work had perished, and the artists Hitler believed were responsible for creating such works were in fact German Romantic artists. He had stated that these perished works were the true expression of the "German soul." Art of the Reich was to be Romantic, it was to be passionate yet "clear and simple,"65 and it would be the artist trained in styles of traditionalist genre who would make it so.

Obviously, Romanticism was linked to the völkisch

${ }^{64} \mathrm{~J}$. Noakes and G. Pridham editors, Nazism V. I 19191945 (New York: Schocken Books, 1983), p.399. Baynes, (ed), The Speeches of Adolf Hitler. Op. Cit. pp.589-92. ${ }^{65}$ Ibid. , p.588. 
tradition. These ideals of Romanticism would be expressed through the history of the people themselves. They would provide the subject matter for "authentic" German art. But in order for this to be expressed, the "new" German artist must be Romantic in spirit and style. This would be Hitler's ideal expression of a new day, a new age of German art.

To get this new art to the nation, Alfred Rosenberg and Robert Ley took over responsibility for coordinating the cultural influence on the people. A highly organized cultural machine was put to work. The Deutsche Arbeitfront was given a special sub-section known as Kraft durch Freude, or "Strength through Joy." 66 It was given special orders to spread culture on a massive scale, to spread culture to the mass of the German people. The Nazis could claim that this was more democratic. . and in fact it was.

The idea of a racially pure, "healthy" culture- a "healthy" aesthetic uniting the masses was a major concern of the National Socialists. They saw this as the creation of a culture based on the national Volk but it must be a culture in which every member of the Volk could participate. This "new" Germanic culture would

${ }^{66}$ The German Worker's Front. Adam, p.73. 
span the demography of Germany's population and reach all levels of society. Art would function for the masses, not simply for an elite class of Germans who could afford to patronize it. In fact, "Strength through Joy" would be responsible for the dissemination of art to the common man.

"Strength through Joy" would sponsor mass tourist visits to galleries and museums, while in charge of the nation's art education. In 1934, the Visual arts section was founded to bring art to the country's factory worker's. Rosenberg wanted a bridge built between the worker and the artist. Over 120 art exhibits were held in factories all over the country. ${ }^{67}$ By 1937, 743 of these exhibits were held. ${ }^{68}$ Prices were kept low so that the average factory worker could afford to patronize the new German art. These efforts made by the "Strength through Joy" division were aimed at synchronizing the tastes of the people, and also to elevate the tastes of the working class to that of the middle class. The German art magazine Weltkunst was quoted as saying:

Adolf Hitler's state had made it its responsibility to embrace all art, in past and

${ }^{67}$ Adam, p. 73 
present forms, and to absorb it into the great idea of the Volk. ${ }^{69}$

Quoted in The New York Times, Bavarian Minister of the Interior Adolf Wagner stated that with this new found German unity, Adolf Hitler had almost single handedly saved the German people from "decline and destruction," and made the nation great. ${ }^{70}$ Wagner, discussing the exhibit of Nazi art in 1937, stated that the "greatness" of that which is German, and made it a privilege to be a part of the German Nation.

But transcending all else in greatness and security as witnessed in this exhibition is the certainty that today and in all other ages there does not and did not exist a civilization without Deutsche Kultur. What a glorious privileged it is to belong to a people of which this can be said. . . without presumption. ${ }^{71}$

Hitler would institute the "new order," one Reich, one People, one leader, one Art. Art would once again regain its treasured status in German culture. Art would be restored to the "noble representation," the epitome of German greatness and become "the idealistic guide in the historical task of leading the Germans out of the wasteland of modernity and into the security of

${ }^{6}$ "Kunst und Kunstler im Dritten Reich," Weltkunst, April 3, 1938. Found in Adam, p.9.

${ }^{70}$ The New York Times. 17 July, 1937.

${ }^{71}$ Ibid. 
the völkisch community."72 Hitler remarked in a speech made 14 June 1938. He believed the international art world would come to Germany and convince itself that once again Germany had become the guardian of European culture and civilization.

...We realized that we had to give to the first national state which was purely German in character those cultural features which it was destined to bear through the centuries alone. ${ }^{73}$

The world all over was to be in awe of Germany's cultural greatness. Moreover, art was to reflect the evolution of German culture from the state of "degradation" to that of cultural dominance. The government of the Reich plotted a course for the creation of a new, heroic German art. The politics encapsulating the German art world would become even more heated. The creation of this art would go forth unhindered, with the assurance that all aspects of Germany's cultural life be controlled by the Reich.

The Nazis believed the community would respond to images of the great German landscape, "the Fatherland," the mystical union of the völkisch community to the earth. The Volk, the peasant farmer, would be core to

\footnotetext{
${ }^{72}$ Grosshans p.28.

${ }^{73}$ Translated by Norman H. Baynes, The Speeches of Adolf Hitler (New York: Gorgon Press, 1981), Vol.1, p.570.
} 
Nazi art, for it was central to Nazi political dogma. The peasant father and mother, images of the soldier, the worker, the roles of men and women under the "new" Reich would be explicit and blatant.

The Nazis were able to control every artistic endeavor under the Reich. With the outlawing of modern art, the thwarting of professional art criticism, and the nazification of the German artist, the Nazis exercised total control over the German art world, and enjoyed seeing the fruition of their political ideology come to life visually through Nazi painting. 


\section{CHAPTER 3}

Kinder, Kirche, Küche

The Politicized Role of the German Woman

Emancipation of woman from the women's emancipation movement is the first demand of a generation of women which would like to save the Volk and the race, the Eternal-Unconscious, the foundation of all culture, from decline and fall. ${ }^{74}$

\section{Alfred Rosenberg}

The roles designated for women in the Third Reich were at best schizophrenic. The pictorial representation of these politicized roles, defining the "true" German woman would lambaste women with the ideal, yet the reality of the German woman was anything but ideal. The images of the woman in Nazi paintings would portray woman's role within the new order: how she should look, act, and simply how she could contribute to the "new" German culture. Ultimately, the "truth of the German woman" would be revealed by the artist's brush.

\section{The Cradle}

An extensive campaign to remove women from the public sphere in Germany was launched as soon as Hitler took power in 1933. This was known as the "back to the

\footnotetext{
${ }^{74}$ From Alfred Rosenberg, Der Mythos de $X X$. Jahrhunderts (Munich: Hoheneichen-Verlag, 1930), p.512. (This has been taken from the 1938 edition.), found in Mosse,p.40.
} 
home campaign."75 Because the Nazis believed deeply in the separation of the sexes and division of labor according to sex, women were to be taken from the public sphere and placed in the private. The Völkischer Beobachter in 1936 declared:

It must seem amazing that women and girls should return to work at spinning wheels and weaving looms, but this is natural. . . This work must be taken up again by the women and girls of the Third Reich. ${ }^{76}$

The Nazis believed that the National Socialist state would in fact be supported by two separate worlds. The public/male sphere and the private/female sphere. If in fact men and women were to accept their roles according to sex, the Reich would only benefit. Man was to be warrior, woman was to be homemaker. Hitler in his address to women at the Nuremberg Party Congress on 8 September 1934 stated:

If one says that man's world is the state, his struggle, his readiness to devote his powers to the service of the community, one might be tempted to say that the world of woman is a smaller world. For her world is her husband, her family, her children, and her house. But where would the greater world be if there were no one to care for the small world?...

${ }^{75}$ The Nazi movement to entice women back into the home. Detailed by Kirpatrick,pp.190-96. Found in Ramona M. Rose, Position and Treatment of Women in Nazi Germany. (Vancouver: Tantalus Research Limited, 1958), p.7. ${ }^{76}$ Völkischer Beobachter, February 2, 1936. Found in Adam, p.156. 
Providence has entrusted to woman the cares of that world which is peculiarly her own, and only on the basis of this smaller world can the man's world be formed and built up. ${ }^{77}$

The German woman would be the keeper of the "germ plasm," the keeper of the "racially pure," the guardian of the National Volk. ${ }^{78}$ This was considered "womanly" work. She was to be the spiritual guardian- of the life process. The German woman was to bear the burden of the Nazi racial state, and her spheres would be comprised of Kinder, Kirche, Küche, or children, kitchen, and church. Hitler discussed the reasoning behind keeping woman in her separate sphere:

Woman because she springs from that root which is the prime cause of life is also the most stable element in the maintenance of a people. She it is who in the last resort has the infallible sense for all that is necessary if a race is not to perish, for it will be her children who will be the first victims of that disaster. Man is often far too mentally unstable to find his way immediately to these fundamental truths. ${ }^{79}$

Again women are fundamental in the sustaining of

\footnotetext{
${ }^{77}$ Translated by Norman $\mathrm{H}$. Baynes. The Speeches of Adolf Hitler (New York: Gorgon Press, 1981), vol.1,p.528. ${ }^{78 " W o m e n}$ were to be the guardians of the germ-plasm, cherish the German tradition, and be comrades rather than competitors. . ." Quoted in Clifford Kirpatrick's Women in Nazi Germany. (Great Britain: The Mayflower Press Plymouth, William Brendon and Son, Ltd., 1939), p.114-15. Found in Ramona M. Rose Position and Treatment of Women in Nazi Germany. (Vancouver: Tantalus Research Limited, 1958.), p.8.

${ }^{79}$ Ibid., p. 529.
} 
the völkisch community. Persuading women to adopt this role as their primary function for the state was one of the National Socialists' main objective regarding women under the regime. The pictorial Review in 1934 quoted the head of the German Woman's League, Lydia Gottschewski:

The best of life, will be for the woman once more to become a Hausfrau and mother, such a German family needs; a woman who feels in its greatest importance the responsibility of bringing a new generation into the world and guiding it sail. ${ }^{80}$

The German woman was to be arbiter over life and death, the life-force of her nation. ${ }^{81}$ she was the keeper of racially pure German stock for future generations. Because Nazi doctrine enforced this, great care was taken, and gentle persuasion was needed. It had only been a few decades since the great Gebarstreik in which many women rebelled against having children

${ }^{80} \mathrm{Dr}$. William Seaver Woods "Germany faces a baby famine." Pictorial Review, September 1934, pp. 7t, 6667. Found in Ramona M. Rose Position and Treatment of Women in Nazi Germany, as viewed from the perspective of the English Language Press -- 1933-1945. (Vancouver, Canada: Tantalus Research Limited Publisher, 1984), p.20. ${ }^{81}$ Eva Kriner-Fischer, "Die Frau als Richterin über Leben und Tod ihres Volkes." (Berlin, 1937),pp.3,12-13. Found in Jill Stephenson's Women in Nazi Germany. (New York: Harper and Row Publishers, Inc. 1975), p.45. 
just before the beginning of World War I. ${ }^{82}$ Many Nazi officials remembered this no doubt and understood the need for cautious action.

One of the first priorities in the creation of the new German woman, and the building of the racial state was the creation of preventive measures ensuring that marriages between Aryan and "non" Aryans would not take place. Such laws as the Nuremberg laws of 1935 in which the latter was prohibited, and the passing of provisions like the marriage health laws of 1935, sprang from the 1933 passage of the Law for the Prevention of Hereditarily diseased offspring. ${ }^{83}$

The Nazis went to great measures to prevent "biological pollution" of the Volk. To ensure that these laws were in fact enforced, a couple deciding to marry was to obtain a certificate from the local health office affirming that both man and woman had been medically examined and were by definition, suitable for marriage. The Party's Racial Policy office, the RuSHA even launched a campaign, reminding German women of the ten rules or commandments for choosing a spouse.

${ }^{82}$ Working class women were urged not to have children for a regime which did not provide adequate sustenance for their children. Found in Jill Stephenson's, Women in Nazi Society.p.188. ${ }^{83}$ Ibid., p.41. 
1. Remember you are a German!

2. Remain pure in mind and spirit!

3. Keep your body pure!

4. If hereditarily fit, do not remain single!

5. Marry only for love!

6. Being a German, choose only a spouse of similar or related blood!

7. When choosing your spouse, inquire into his

or her forebears!

8. Health is essential to outward beauty as well!

9. Seek a companion in marriage, not a playmate!

10. Hope for as many children as possible! ${ }^{84}$

This list of "commandments" was supposedly to alert racially pure Germans to the dangers of choosing a partner who was not racially "fit." Although the primary stipulation was to "marry for love," the motive here is obvious. A loving couple, and a healthy woman would provide a stable home, and produce happy, healthy children, provided they were racially pure. ${ }^{85}$

Party officials tried to induce women to have children, and the elevation of the mother to the figure of national heroine proved to be a powerful persuader. The Völkischer Beobachter announced that honor cards were to be given to all mothers with at least three children under the age of 10. The cards were to be carried, and on the reverse, was a request to all offices and shops to give the holder preferential

${ }^{84} \mathrm{Claudia}$ Koonz, Mother's in the Fatherland. (New York: St. Martin's Press, 1987), p.189.

${ }^{85}$ Ibid., p. 189. 
treatment. ${ }^{86}$ On the front of the card there would be the picture of a mother surrounded by small children with the Nazi motto in full view that the most wonderful word was "mother." 87

The prolific German mother is to be accorded the same place of honor in the German Volk community as the combat soldier, since she risks her body and her life for the people and the Fatherland as much as the combat soldier does in the roar and thunder of battle. ${ }^{88}$

The holiday, Mother's Day, was turned into a national pseudo-religious experience. The Völkischer Beobachter commented that the youth of Germany must be brought up with a reverence for the mothers of the nation. The newspaper stated that although the honoring of German mothers with medals and cards a worthy cause, the prolific mother was to be awarded publicly for her sacrifice. ${ }^{89}$

In addition, the wearers of the Honor cross of the German Mother will henceforth enjoy all those privileges which are already possessed as a matter of course by meritorious racial

86' 'Ehrenkarte für Mütter', VB, 18 November 1934. Found in Stephenson, p. 48 .

${ }^{87}$ Ibid, .p. 48 .

${ }^{88}$ From the Völkischer Beobachter, Dec. 25, 1938. (Wiener Library clipping collection) George L. Mosse Nazi Culture (New York: Grosset and Dunlap, 1974), p.45. Translations by Salvator Attanasio et al. ${ }^{89}$ The $\underline{V B}$ announced that every mother wearing the honor cross, must be saluted by the youth of the country as if she was a soldier. Found in Stephenson, p.50. 
comrades... ${ }^{90}$

The rank of the German mother would be that of racial warrior. She would stand by the sides of disabled war veterans, and the "martyrs" of the National Socialist Revolution. Such privileges would include preferred seats on trolleys, rail coaches, special treatment in governmental offices, and special old-age care. With all this, the German mother would know the worthiness of her duty as well as an "expression of thanks" from the Führer and the German people.

This adoration of the German mother was done so in the hope "that they will continue to help to pave the way for our people, and that they will make as a gift of that youth which, after perilous times, will crown the race of our Volk...." 91

Commenting on Mother's day, or Mothering Sunday, as it was referred to in a newspaper from the Northern German city of Eutin, the reasoning behind such ceremony is elaborated.

We must also be grateful to the mother because she is the source of strength of a nation. Today's mothers have experienced and seen much, and were called to carry out tasks during the World War while their husbands, sons and grandsons were fighting at the front.... The

${ }^{90}$ Ibid., p. 46. 
place of the mother as a focal point of the nation had been undermined during the postwar period. Today Adolf Hitler has again restored the German mother to her noble and saintly position in the heart of the people. ${ }^{92}$

Such ceremonies honoring the mother were reinforced by Party officials and their dogma. Alfred Rosenberg stated that it was the woman's task to maintain the purity of race for women thought in "lyrical" terms and not logically. ${ }^{93}$ This was considered her strength. Reich women's leader Gertrud Sholtz-Klink, in full agreement, called upon women to become once again the priestesses of the family and of the nation, ${ }^{94}$ while Martin Bormann demanded that for the sake of Germany's future the National Socialists would have to practice an effective mother cult. ${ }^{95}$ SS-Führer Himmler along those lines stated that unless Germans could purify and further bloodlines, the great Germanic empire would not

${ }^{92}$ From "Anzeiger für den Hankreis Eutin, May 22, 1939," in Lawrence Stokes, ed., Kleinstadt und Nationalsozialismus: Ausgewählte Dokumente zur Geschichte von Eutin, 1918-1945 (Neumünster: Karl Wachholtz Verlag, 1984),pp.895-96. Benjamin Sax and Dieter Kuntz, Inside Hitler's Germany (Lexington, MA: D.C. Heath and Company, 1992),pp.266-67. Translated by Dieter Kuntz.

${ }^{93}$ Rosenberg quoted in Mythus. Found in Fest,p.267. ${ }^{94}$ Quoted by Hans Kerrl, ed., Reichstagung in Nürnberg 1935 (Berlin, 1936) Found in Fest,p.267.

${ }^{55}$ Memorandum of Martin Bormann "Sicherung der Zukunft des deutchen," January 29, 1944. By Jacobson and Jochmann, Aushewählte Dokumente. Fest, p.272. 
be able to maintain itself. ${ }^{96}$

In this we see woman's place helping to build the empire. This pseudo-romantic ideal, fronting for political and imperialistic achievements only reinforced the woman's role as warrior of the womb. In 1936 Hitler declared to the National Socialist People's Welfare Organization:

We alone are entitled, to lead the people as such -- the individual man, the individual woman. We regulate relations between the sexes. We mold the child! And elsewhere children belong to their mothers as at the same moment they belong to me. ${ }^{97}$

The new ideal type of woman would be contrasted with the "protesting" 98 images of the suffragette movement, (even the female party officials at times). Hitler had stated in a 1932 interview with the National Women's Organization that the Revolution of 1918 had not emancipated women, or made them equals. Women were

\footnotetext{
${ }^{96}$ Himmler's speech to the SS Group Leaders' Conference in Poznan in October 1943; see IMT XXIX, 1919-PS. Found in Fest, p.272.

${ }^{97} 1936$ Reich Party Rally, in "Offizieller Bericht über den Verlauf des Reichsparteitages mit sämtlichen Kongressreden." (Munich, 1936). Quoted previously from Hitler's speech at the inauguration of the Ordensung Sonthofen on November 23, 1937; see Domarus Hitler, vol I. Found in Joachim C. Fest. The Face of the Third Reich (New York: Pantheon Books, 1970), p. 26. 98 The RAD (Reich Labour Service) tried to incorporate women into National Socialism. Hans Retzlaff, "Arbeitsmaiden am Werk." Found in Fest,p.270.
} 
turned into, what Hitler had called "blue stockings" and entered the realm of man. "Under the Third Reich, they might as well whistle for such things. Every woman then will get a husband for herself." 99 The German woman was to, by virtue of her ideological and biological predisposition, belong to Hitler, the state, and provide the Volk a "living example of National Socialism."100 If, in fact, a German woman could not find a husband or could not marry, the Reich too made provisions for the unmarried mother. This was so, provided the woman was bringing into world a child that was "racially pure."101 Himmler had stated that the acceptance of the unmarried mother would not somehow lower the status of the married woman. ${ }^{102}$ However, this "tolerance" towards the unwed mother was seen as a means to elevate her to a worthy status within society. Himmler believed the unmarried mother was a particularly vulnerable member of society, she needed protection by the state. Upon this realization, Lebensborn homes were created for expectant married and unmarried women who found themselves in times of financial hardship. In

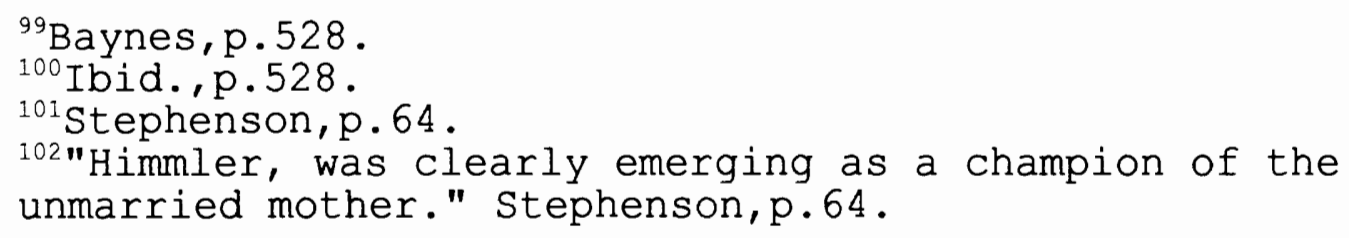


particular, these homes were to provide assistance for the wives of SS men. ${ }^{103}$

The problem of the young pregnant woman alone while her husband or lover was fighting at the front was a repeated scenario during the period of war. Rudolf Hess found this to be extremely problematic. ${ }^{104}$ What were these women to do on the chance that the male in their life would not return. Hess and Himmler had the solution. They unilaterally announced that the Nazi government would be prepared to assume the guardianship of children whose fathers had perished at war. ${ }^{105}$ In doing so, Himmler believed that German society would break free of the moral conventions of the middle class, and allow for the equality of the unmarried mothers child. ${ }^{106}$

All mothers' children should be incorporated into the future Volk. All mothers were to serve the state and compensate for the bloodshed during war. It is this

${ }^{103}$ IfZ, MA 387, frames 5189-95, 'Verein "Lebensborn" e.V.', 31 May 1937. Found in Stephenson, p.64.

${ }^{104} \mathrm{BA}, \mathrm{R} 43$ II/1286, letter from Frick to Lammers, 24 December 1939. Found in Stephenson, p.66.

${ }^{105}$ Ibid., letter from Hess to the financée of a dead soldier, n.d. (covering letter, above, dated 24 December 1939) Stephenson, p.67.

${ }^{106}$ Kersten, op.cit.,pp.176-82; Hans-Jürgen Lutzhöft, Der nordische Gedanke in Deutschland 1920-1940, (Stuttgart, 1971), pp.395-6. Found in Stephenson, p.70. 
ideal which Hess helped to summarize. It was to be the loss of life which should be German mothers primary concern. Hess had stated that producing future generations should take precedence over any other moral conviction. ${ }^{107}$ She must obey her duty, whether she be married or unmarried, and she must participate in the propagation of the Volk.

If in fact a woman chose not to have a child, married or unmarried, it would be considered treason. She would be considered amongst the likes of army deserters. ${ }^{108}$ In the SS weekly, Das Schwarze Korps, Himmler was quoted as saying that in war time, no soldier should go to the front without leaving an heir. ${ }^{109}$ With this seemingly loosened "morality," women who had a child out of wedlock could be confident that the government would support and welcome their condition. There was some opposition to this, most of which came from the Catholic church which saw this plan as sinful and degrading to the "sanctity" of marriage. Nonetheless, the German woman was to be preparing the

${ }^{107} B A, \quad R 43 I I / 1286$, letter from Frick to Lammers, 24 December 1939. Letter from Hess to un-wed mother. Stephenson, p. 66-7.

108 'Der Sieg der Frauen', Das Schwarze Korps, 4 January 1940 . Stephenson, p. 67. ${ }^{109}$ Ibid., Stephenson, p. 67. 
national Volk for world domination.

The means by which the Nazis went to increase the German population, would be by creating an atmosphere which was conducive to procreation. They needed to create an environment which was suitable for sexual activity. Robert A. Brady, author of The Spirit and Structure of German Fascism, discusses that in this environment, the German woman's loyalties were to men, and the state, her roles were that of housewife, mother, and propagandist. If the German woman fulfilled her role correctly, an environment would be created sponsoring "healthy" male/female relationships.

of all roles determined for women it was their femininity which ultimately defined these roles. The Nazis believed all women to be loyal and dutiful, and would therefore accept their roles for the Nation proudly. Alfred Rosenberg, leading Nazi ideologist, wrote in his work titled Der Mythos des XX. Jahrhunderts the woman does absolutely belong to her people.

\section{To Be Authentic and German}

Besides the Nazis' attempt to drive women back to the home by glorifying motherhood as a woman's true profession, they also attempted to project a 
corresponding physical type of German womanhood.

However, this archetype changed repeatedly during the National Socialist period.

The ideal woman in Nazi theory was the peasant wife, whose peaceful, wholesome life was devoted to her work on the land and, above all, to her family. The ideal image of this Teutonic/Aryan female at her kitchen table with babes at hand was offered as the alternative to the urbanized image of women of the Weimar period.

It was the excesses of the twenties and its influences upon the German woman, Party ideologue Alfred Rosenberg chose to fight against. ${ }^{110}$ Rosenberg believed that the Weimar period caused weakened family values, as well as weaken sexual mores. The "true" nature of German conservatism had been "corrupted." The twenties woman was seen as unfeminine, wearing shorter hair, binding her breasts, donning straighter and shorter skirts, and she was also see as the root of the loosening sexual practices. The overall period of emancipation during the Weimar era gave women many freedoms. Women were marrying later in life, women had the vote in Germany in 1919, before women in the United State's received the vote. Women were entering the ${ }^{110}$ Ibid., p. 40 . 
work force in greater numbers than before. Yet woman's modern image would not be tolerated by the Nazi party and they fought to dismantle it.

Women's clothing had larger implications. Nazi ideologue's condemned foreign influences of Paris and the United States. They claimed that such influences had encouraged German women to become frivolous. There was in fact an overt emphasis on creating a "German style" but the woman's magazines continued to carry "decadent" fashions from abroad. Because of this many Nazi officials objected to German women reading fashion magazines, for they felt that these magazines would endanger the German woman's moral character. ${ }^{111}$

Magda Goebbels, however, felt that the "unfeminine" portrayal of German women was unfair. Although beauty and exercise were important, Frau Goebbels did not want the German woman to be considered drab. She went so far as to create a new German fashion institute that would work toward making the German woman more "beautiful."112 Frau Goebbels' believed that the Nazi male wanted to see

111'Planmässiger Kampf gegen würdelosigkeit im weiblichen Geschlecht, von einem Beobachter am Wege', Frankfurter Zeitgemässe Broschüren, January 1916, pp.2-4. Stephenson, p.191. ${ }^{112}$ Katherine Thomas, English speaking press,p.73. Rose, p. 26. 
women with permanent waves and lipstick, not in a stuffy brown uniform and in a low heel. Her illustrious dreams to make the German woman more appealing were shortly thwarted. The fashionable German woman would be eliminated for the former robust ideal. After rearmament, the fashionable archetype was gone for good. ${ }^{113}$

Himmler too had maintained strict rules regarding the dress of women in the SS Lebensborn home. Women would not paint their nails, wear lipstick, or shave their eyebrows. ${ }^{114}$ In fact, in many fashionable cafes around Germany hanged large banners reflecting the National Socialist stand. Women should not drink or smoke, for it would be un-German to do so. ${ }^{115}$ The proper appearance of the German woman was methodically defined by such restrictions. Since, the ideal type of woman in Nazi theory was the peasant wife, the conservative/rural realm was to be the only sphere in which the German woman was allowed to exist. It was her only means for assimilation into the Nazi dynamic.

${ }^{113}$ Ibid., p. 26.

${ }^{114}$ IfZ, Fa202, frame 78, letter from 'Dr E.' to the Council of Lebensborn, 6 September 1940. Found in Stephenson, p.191.

${ }_{115}$ "Die deutsche Frau raucht nicht," FZ, 1 May 1933; Eliabeth Wiskemann, The Europe I Saw. (London, 1968),p.34. Found in Stephenson,p.190. 
Although the Nazis stated they no longer wanted women who could dance nicely at "five o'clock teas," as Himmler had put it, women were still to be attractive to the male Nazi. ${ }^{116}$ The "fashionable image" of women would transform into another ideal. The German woman would leave her worldly emancipated traits for those of submission and sexual provocativeness. Obviously, this was an inconsistent portrayal of the German woman at best. The German woman on one hand would be the eternal mother of the Volk and on the other represent the naive sexual libertine awaiting the dominant male force, simultaneously she would be the mother and the virgin. Writer Curt Rosten's pamphlet The ABC of National Socialism stated:

But German men want German women again, and quite rightly. Not a frivolous plaything who is superficial and only out for pleasure, who decks herself with tawdry finery and is like a glittering exterior that is hollow and drab within. Our opponents sought to bend women to their dark purposes by painting frivolous life in the most glowing colors and portraying the true profession allotted to woman by nature as slavery."117

A poem by Curt Rosten reads as such:

${ }^{116}$ From Der "SA-Mann," Sept.18,1937, (Weiner Library Clipping Collection.) Found in Mosse, p.47-53. ${ }^{117}$ On the "Rescue" of the German woman, curt Rosten's book titled $A B C$ des National Sozialismus, Found in Fest, p.268. 
We want our women tried and true

Not as decorated toys.

The German wife and Mother too

Bear riches no foreign woman enjoys.

The German woman is noble wine.

She love and enriches the earth.

The German woman is bright sunshine

To home and heart.

Worthy of respect she must always be seen;

Not of strange races the passion and game.

The people must remain pure and clean:

That is the Führer's high aim. ${ }^{116}$

Nonetheless, women were to be attractive to men, pure and simple. These ideals of purity and simplicity would characterize the "true" German woman. She would find her place not in the social realm, but in the erotic, almost a type of rural-eroticism.

It was not as if the Nazis hated the femininity of women. The Nazis simply placed emphasis on a particular type of femininity. Party officials alike believed that healthy "Nordic" femininity would be the most attractive to the true Germanic male. Nazi ideologes believed they were reconstructing an ancient Germanic type of femininity, traceable back to the early Aryan tribes. Reaching far back into German mythology, the German woman would be:

the deity of Valhalla, who could fight, ride, and drink as hard as any man...the broad hipped,

${ }^{118}$ Ibid. , pp $.377-78$. 
muscular Valkyrie Brunhild who could throw the heaviest Javelin further than any masculine athlete and could defeat every male adversary in wrestling matches. ${ }^{119}$

The German woman would embody the erotic, the erotic being strength and beauty.

The Nazis believed these were characteristics of the German female which had always existed, yet they somehow were suppressed by the modern world. It was part of her national character and could not be erased from her being. Yet as stated before, the strong Germanic mother warrior would not be the only element making up the new German woman.

The dual role devised for women by the Nazis would only add to the confusion felt by most German women who heard the National Socialist message. It would only elevate the confusion and indecisiveness which encapsulated the Reich's overall position on women.

\section{Das Mädel}

With the processes of female emancipation eliminated, woman's degradation became an element of Nazi tradition. Many historians believe that the term Mädel is key in this process of degradation. Hermann

${ }^{119}$ From Ernst Klein, "Women in National Socialism," Fortnightly, 157 (April 1942),p.286. Rose,pp.27-28. 
Glaser author of The Cultural Roots of National

Socialism states that the term Mädel or maiden was central to her depersonalization. ${ }^{120}$ In previous times, Mädel was an expression applied mainly to the object of a young man's sexual desire. The maiden represented the "bad" conscious of men that was countered and appeased by the maidens sweet sentimental innocence.

The bad consciousness caused by this rather matter-of-fact and dehumanized instinct was appeased by a sweetly sentimental idyll: though Mädel on the one hand was pert, forward, rather libertine, and therefore easy to have, she was on the other hand touchingly naive, frightened and troubled. ${ }^{121}$

The attention for Mädel was increased by the promise of seduction of the innocent and her corruptibility which was the erotic enticement, such as the corruption of Marguerite in Goethe's Faust.

"Gretchen" became the object of Faust's desire and ultimately was corrupted by the older doctor and died of a broken heart. ${ }^{122}$ This caricature remained deeply

${ }^{120} \mathrm{Glaser}, \mathrm{p} .178$.

${ }^{121}$ Hermann Glaser, The Cultural Roots of National

Socialism. (Austin: University of Texas Press, 1978), p.178. Translated by Ernest A. Menze. Originally published in 1964 as Spiesser-Ideologie: Von der Zerstörung des deutschen Geistes im 19. und 20. Jahrhundert.

Iz<The "Gretchen" character out of Goethe's Faust was the simple, pure, object of male desire. She was ultimately corrupted by Faust and later died of a broken heart. The portrayal of the German woman as "Gretchen," found 
entrenched in German literature and thought. "Gretchen" would forever remain the sweet innocent creature, whom would fall prey to corrupting gentlemen. Even with the advent of Klassik, and the adoration of the heroine, with such figures as Helen of Troy, 123 "Gretchen" still remained deeply entrenched in German traditional ideology. She remained the naive sweet young girl, capable of the capture of a young man's sexual longing. Ultimately, the classical heroines too contributed to the centrality of the physical and relations to the social world. The heroine's beauty is indeed central to the narrative. ${ }^{124}$ Even in such neo-platonic tradition, the dualistic nature of reality existed in the narrative. Good was linked to beauty, evil with that of the ugly. "Gretchen," in her various forms of "beauty," however, would find their way into Nazi art. "Gretchen" as Heinrich Duntzer remarks:

Has become the pure maiden, in the neat parlour with a snow white bed, inspiring Faust's, "sweet yet sacred shuddering," "Gretchen's soul," reveals itself to the loved one with all the goodness of her heart, purity and innocence; her

fruition in official nudes.

${ }^{123}$ Ibid, p. 178 .

${ }^{124}$ Referred to throughout Linda K. Worley's "The Body, Beauty, and the Woman: The Ugly heroine in stories by Theresa Huber and Gabriele Reuter." The German quarterly. Vol.64. Summer 1991, No3. 
love breathes air of all her virtues. ${ }^{125}$

With the advent of National Socialism, "Gretchen" was no longer the object of pity; but rather the object of adoration. "Gretchen" became the embodiment of pure love and beauty. She was something to be protected. It was not that "Gretchen" became the embodiment of purity in her own right, but rather the purity of Das Mädel which could be coveted by the male.

The patriarchal covenant of marriage became the only "suitable" state for "Gretchen." This arrangement kept "Gretchen protected" still troubled but in a safer situation. Her sexuality too now was under safe keeping by the courtly gentleman. Through marriage, "Gretchen" could reach her perfection in purity, morality, and beauty. The voyeuristic tendencies surrounding "Gretchen" identify her physical qualities.

But let me tell you of her appearance so neat: the purple pinafore raises the round bosom, tightly bound, and the raven black bodice fits her so snugly. The ruffled neck of the blouse arranged so neatly caresses the features of feminine grace; the heads of tender roundness rises freely and clean; the strong braids entwine the silver ornaments; richly pleated and blue, skirts fall from the waist. ${ }^{12}$

There is no question about "Gretchen's" appearance,

${ }^{125}$ Ibid., p. 179
${ }^{126}$ Ibid., 
what about her social status. Nazi ideologes believed that a wife must in time learn to serve. "Gretchen" is now married, but she must also understand that marriage too is a hierarchy. Glaser notes such phrases synonymous with the servitude of the maiden:

I will serve him, live for him, always be his own will, given myself and find myself transformed by his renown: a gold pledge of love, has proved my finger fine and piously, I touch the lips, hold you close to this heart of mine. ${ }^{127}$

Hermann Glaser states that it was phrases such as these which were attached to the personification of "Gretchen," no doubt to inspire the longing of every German male. ${ }^{128}$ The phenomenon known as Geschlecharakter, an ideology of 19th century origin, in which the female appearance takes center stage. Woman's power would ultimately be linked through the beauty of her face and body.

The link between woman and body was particularly strong in the 19th century. Beauty defined purity. The ideal of Geschlechtscharakter, emphasized biology.... Within the system of separate spheres, male power could be an agonic show of force while female power was linked to the hedonic power of display. ${ }^{129}$

${ }^{127}$ Ibid., p. 180.

${ }^{128}$ Referring to Adalbert von Chamisso poetic love life. Glaser,p.182.

${ }^{129}$ Linda Kraus Worley, "The Body, Beauty, and Woman: The Ugly Heroine in Stories by Theresa Huber and Gabriele Reuter" The German Quarterly. Vol. 64. Summer 1991, No. 
The National Socialist maiden would "display" an almost empty idealism. She would possess no ability to think, bodily appearance alone would animate her "Gretchen" would be categorized by her willingness to serve, her display of beauty, her potential birthing force, and her spirituality, if you will, defined by the above. This sense of purpose was in reality void of any intellect or spirituality. Yet this was the role created for women under the new Reich. Faith and beauty were the designated elements of Germanic womanhood, and it would be this caricature which would define the woman in Nazi political art. The artists working for the Reich were given specific instructions. The German woman was to be an idol.

Women were forced into confining romantic ideals such as the female warrior, or Das Mädel. However, it was these romantic ideals which helped to shape the minds of the middle class, and as stated before, it is this portion of the German population from which Hitler drew his strength. It was the bourgeois whom held on to these romanticized views of women as Glaser notes, ${ }^{130}$ and it was this segment of the population who would support

$3, p .368$.

${ }^{130} \mathrm{Glaser}, \mathrm{p} .187$. 
and be influenced by Nazi commissioned art work. It is this bourgeoisie consciousness which helped keep "Gretchen" alive and well. The new "Gretchen" would be the complete caricature of the woman under the domination of the new German Reich. She would be pretty, innocent, pious, and ultimately quite bound to her "duty."

The Nazi artist would use this caricature of the German woman and give it "life" on the canvas. The German woman would see her "duty" to the Reich and the representation of her model-self, time and time again reinforcing her place within the Third Reich by the brush of the artist. As discussed, the German woman was to be a mother, something wholesome and pure, yet something which could capture the fancy of a soldiers heart. This was Nazi ideology regarding women. Women were to rally behind Nazi political dogma and accept their roles for the good of the nation. The paintings provided the gentle persuasion needed, where policy could fail. 


\title{
CHAPTER 4
}

Imagery: Politicizing the Unpolitical

\begin{abstract}
The mission of woman is to be beautiful and to bring children into the world.... The female bird pretties herself for her mate and hatches the eggs for him. In exchange the mate takes care of gathering the food, stands guard, and wards off the enemy..$^{131}$
\end{abstract}

\section{Joseph Goebbels}

In reality women were working in factories and trying to make ends meet. However, this quote by Joseph Goebbels could in fact be the quintessential ideology behind the depiction of women in Nazi art. Woman's predetermined role in Nazi Germany, even in its rudimentary form, took root within Nazi law and platform. It was expressed and given fruition through the Nazi aesthetic. For all intents and purposes, women were depicted as the erotic, i.e., the life force inherent in nature, connecting her to the land, as mother of the Volk, or as the dominated "Gretchen" sweetly submissive with a hint of the libertine. Hitler stated: "Equal rights for women means that they experience the esteem that they deserve in the area for

${ }^{131}$ From Joseph Goebbels, Michael: Ein duetsches Schicksal in Tagebachblättern. (Munich: Zentralverlag der NSDAP, Frz. Eher Nachf., 1929) (Wiemar Library Clipping Collections). This extract has been taken from the 1934 edition. Found in Mosse, p.41. 
which nature has intended them." 132

Goebbels' added to this ideal and stated that it is the task of the woman, because of her innate connection to nature, to be that of wife and mother. Nazi officials believed that they themselves would be able to give the woman back this "essential honor." The Nazis did not create a space for the characterization of the political woman under the new Reich. However, the German woman's role as wife and mother was an essential element of National Socialist political ideology.

\section{Divine Motherhood}

Under the Third Reich, as discussed before, motherhood was woman's most important role, it was her greatest contribution to the new Reich. Mary McNicholsWebb states that this role ultimately alienated her from culture in National Socialist Germany. The image of woman as child bearer is her association with nature. Many feminist scholars have termed this as the "will to nurse" or the "will to birth." McNichols-Webb states: ...culture has ordained that woman has no need

${ }^{132}$ Hitler quoted in David Schoenbaums' Hitler's Social Revolution (Garden City, New York: Doubleday, 1966),P.190. Mary McNichols-Webb, Art as propaganda: A comparison of the imagery and roles of woman as depicted in German Expressionist, Italian Futurist, and National Socialist Art. U.M.I., Ann Arbor, MI. 1989), p.242. 
of culture and culture no need of her. As so she is excluded for the life of her society. One of the means of the exclusivity is to make her a mother. Motherhood, as Adrienne Rich describes it so clearly and unforgettably in of Woman Born, is made unnaturally separate, and unnaturally becomes that which keeps woman away from all which might interest her mind or her soul except her infant. ${ }^{133}$

Kinder, Kirche, Küche; these ideals dominated much of the art regarding women. Nazi ideologue's wanted women to be represented within their "natural" realm of homemaking and birthing. The Führer's deputy, Reich Minister Rudolf Hess, stated in 1936:

We want women in whose life and work the characteristically feminine is preserved - women that we can love. We grant the rest of the world the ideal type of woman that it desires, but the rest of the world should kindly grant us the woman who is most suitable for us. She is a woman who, above all, is able to be a mother. ${ }^{134}$

In Richard Heymann's painting In Good Hands (no

date) (1), the message is clear. Woman as mother is the dominant theme. Here a buxom German woman has surrounded herself with babes, the future generations

${ }^{133}$ Mary McNichols-Webb, p. 248.

${ }^{134}$ From an account of a mass meeting of the Berlin National Socialist Women's Organization (Die NS Frauenschaft) and the NS Frauenwerk (Women's Social Welfare) in the Deutschland-Hall, published in the Völkischer Beobachter, May 27, 1936. (Weiner Library Clipping Collection). George L. Mosse Nazi Culture (New York: Grosset and Dunlap, 1968),p.42. Translations by Salvator Attanasio and et al. 
of the Volk. She is not depicted because of her individuality but solely by what her body can offer by means of its biological function. Within this painting there are other thematic depictions other than woman as mother. The status of the sexes are represented as well. There is a little girl, standing off to the side of her mother, playing with her doll, the viewer is not able to see her face, for she is not illuminated, only the sheen of her hair tells the viewer that she has golden hair. Her participation within the painting is relegated to her interest in her doll for, she too is learning her role at an early age- females breed, her future role is that of mother. The little boy in the painting is shown with a much more active stance than the little girl or the mother herself. He stands at the center of the painting between his mother's legs, looking a head, face smiling and illuminated. The boy is holding a toy airplane, while the dominate space he holds within the painting tells the viewer, that it is the boy who will be the creator of culture, the creator of technology, or perhaps be the future Reich leader. However the little girl is standing next to him in the foreground as if to relay the message that women in their proper place as mother, and men in their proper 
role as active participant of science and industry, will be representative of the future social stratification within the Reich. As previously noted, Hitler stated that it was the private realm which supported the public realm. The fact that the boy is standing in front of his mother also implies that he is to be a member of the public realm. The realm of the woman, the "little" sphere would indeed be the support of the greater. Within the painting the active stance of the boy also provides the message that within Nazi society, a male child status wise, comes before an adult female. The German woman, even in the confines of her separate realm, within the family, possesses a second rate status.

Mainstream propagandists and artists alike were quite aware that their praise of motherhood would further Nazi policy. Gertrud Scholtz-Klink believed that women could be convinced they too were part of German history. This ideal was espoused by Nazi officials and traditionalists alike. They believed that art was the representation of that which was a truth, something which had been accepted by the population at large and a celebration of ideals which were seen as elemental to the totality of German life already. The 
implications for the German woman was that she had always been and would always be the "eternal mother." The German mother was always shown in a constant state of fertility as the painting entitled Mother, (no date) (2), by Karl Diebitsch exemplifies. The peasant madonna is prominently posed breast feeding her baby out in the German country-side surrounded by nature, shoes off, and shirt undone. The message relayed is that the woman, because of her ability to give birth, her most noble attribute, is fulfilling her role to the Nation as she was meant to do, simply because of her sex. The states of pregnancy, and childbirth were seen as the German woman's greatest self-sacrifice. To give birth was not a gift but a duty as the life source of the nation, the German woman was the madonna of the Teutonic race.

The German mother was also depicted as a warrior, engaged in her own type of battle: bringing into the world future German soldiers. Hitler stated in a speech to the National Socialist Women's Congress in 1935: "The German woman has her own battlefield. With every child she brings into the world she fights a battle for the 
Nation." 135

The theme of the German woman as warrior is shown in the painting by Hans Schmitz-Wiedenbruck entitled Nation at War, (no date) (3). At the center of the painting is a mother seated, holding a baby in her arms. Around her are the ravages of war. Soldiers are standing behind her (suggesting her martyred status as one of the nation's war heroines), workers are to the right of her, on her left, the German Volk. All are mobilized for war, however, it is the mother who is most valuable of all. She is the Nation, she is the creator of the Nation. The image of the mother was also used to ennoble other sectors of the German population. The soldier, the worker, etc., are somehow validated by simply being represented in the same realm of the blessed German mother. Berthold Hinz suggested that: The mother's presence in the production sector ennobles work, and the working force by linking them to the 'natural order,' and suggested that they too are like her, are blessed and fruitful. As the guardians of the species, she guarantees that social conditions will remain in order just as they are. ${ }^{136}$

${ }^{135}$ From a speech to the National Socialist Women's Congress, published in the Völkischer Beobachter, sept. 15, 1935. (Wiener Library Clipping Collection) Mosse, p. 40 .

${ }^{136}$ Berthold Hinz, Art in the Third Reich (New York: Pantheon Books, 1979), p.57. Translated from German by Robert and Rita Kimber,p.157. 
The natural order is idealized in constantin Gerhardinger's Family portrait, (no date) (4), a mother sits and feeds a toddler on her knee. To her left is a young girl holding a doll pensively staring at a small wooden cradle on the floor, inside is yet another baby. To the mother's right is her husband polishing his French horn. The boy standing behind the mother looks as if he too is working on an artistic endeavor, and could at one time have been gazing out the window. All females in this portrait are occupied with child rearing. Clearly it is men who will propagate culture and learning, and women who will propagate future generations. Subsequently, it is the little girl in the portrait who is learning her role, staring at the small cradle with a look of curiosity.

The German woman depicted in the Nazi painting would be the example model of behavior, personality, body-type, values and morals for future generations of German women. The German woman would be tall, lean, strong and blonde. She and her children were to be of "true" Aryan stock. In Adolph Wissel's Farm Family From Kahlenburg 1939, (5), the ideal German family is depicted again as the farm family, the mother is preoccupied holding babies, all of which are fair-haired 
and rosie-cheeked. The young girls are preoccupied and listless. The little girl to the right of the painting is hard at work drawing, yet her tiny doll is right next to her side, never too far away from her grasp. The other little girl is sitting on her mother's lap, locked in a gaze, her little mind seemingly elsewhere. All adults at the table are shown in profile, grandmother and father looking as is they have been engaged in conversation at some point while the mother rests her head on her little one, looking downward, as if she is almost outside of what is happening at the table. The little boy sitting in the center of the table is the only individual engaged in an active glance with the viewers. He is looking straight forward, eyes locked in a fixed position towards the future. In his hands he is holding a toy miniature horse, the horse symbolizing action of course, perhaps this boy is a future soldier. Scattered around the boy are toy building blocks, perhaps they were his sister's who is now board of playing with them. But the boy has them in front of him, for he is the future builder of the Reich. Below this painting there is a passage by walter Horn which stated, "A young art that contains its passion in simple realism represents the new political 
thinking of our epoch."137 Clearly, for the Nazis, the representation of the sexes in such a way did relay the truth, or realism of male and female status under the Reich.

In Arthur Ressel's Expectant Mother, (no date) (6), the woman is solemn, looking straight ahead as if she is gazing into Germany's future. She is Germany's future. She is also shown with a Christian cross around her neck, (no doubt trying to appeal to Germany's conservative religious portion of the population), the image she portrays is one of purity. Her almost saintly qualities suggest that her duty or mission of giving the Reich future generations is blessed and holy. Her peasant garb denotes a social class as well for this mother, again the context of this painting is centered around the ideal of the peasant madonna, for it is the peasant mother who will bring rebirth and sustenance to the nation.

In Richard Heymann's painting The Heir, (no date) (7), a peasant mother sitting with a baby in her arms is in front of a darkened landscape. She is surrounded by other peasant workers and they look to her in reverence. Illumination on the face and body of her and her baby ${ }^{137}$ Ibid. , p. 148 . 
suggest again that it is the peasant mother who will bring forth the future heirs of the nation, future soldiers, peasant farmers, mothers, and leaders, the building blocks of the thousand year Reich. Indeed, the German woman is that which provides the birthing of a nation, and all the riches that the future inherits. Writer, Friedrich Ludwig Barthel draws paralleled imagery in his piece, "Von Männern und Muttern:

Mothers are ever the same, and lie in the fields spaciously suffering the plough, they sleep so you think; but they take up their joy unto themselves and become. ${ }^{138}$

The German mother was to suffer, for her child and her Reich. The portrayal of the German mother doing her duty for the Reich was to be her joy. She would be depicted time and time again as the as the dutiful wife and mother, knowing her place within her family and the nation. All females young or old, were to understand their future role as mother and care giver to the nation. She too would be depicted as the keeper of nature, the harvest, as provider for the nations Blut und Boden.

${ }^{138}$ Friedrich Ludwig Barthel, "Von Männern und Muttern," Literatur, Jahrgang 39, 1938, quoted in Grunberger. Found in McNichols-Webb, p. 353. 


\section{Blut und Boden}

The Nazis believed that woman was the bearer of the harvest and the nations agriculture. She was to be the care giver of nature, and most comfortable in her "natural" space given to her by nature. Thus woman's place in nature was depicted repeatedly. The German woman was mother earth, mother to the earth, her family and the nation. This was her connection with nature as Peter Adam stated. If woman was nature;

then the most obvious place for the German woman to be placed would be surrounded by nature. She was to be the beauty of nature and possess the playfulness of nature as well as possess the fertility of nature. ${ }^{139}$

The German woman was the keeper of the nations agricultural realm as exemplified in Jürgen Wegener's 1943 painting entitled Thanksgiving, (8), which depicts peasant women coming in with the harvest. They are in a traditional peasant dress. A woman in front of the group is wearing a wreath of wheat around her head and in her arms lay bundles of the harvest. Standing in front of her is a small girl carrying bread with outreached hands, she is offering it, looking ahead as if she is assured that this is a woman's future, her

${ }^{139}$ Peter Adam, Art of the Third Reich (New York: Harry N. Abrams, Inc., Publishers, 1992),p.150. 
place is to be in nature with her livelihood propagated by agriculture. Both the woman and the girl are illuminated as if to show the viewer that the peasant, primarily the peasant female, is the backbone of German agriculture, the backbone of the nations harvest. This painting also sends a message that it is the peasant woman who is the sole support of the Volk spiritually and realistically, spiritually, for the elemental characteristics of German spirituality was to come from the soil itself, and realistically because it is the peasant who provides the sustenance for the Reich. This ideal depiction of traditional German life depicts the peasant woman at its core. As we have discovered, Nazi artists and ideologes alike assumed that women were inherently linked with the "blood and soil" of the Volk. Rewards of Work, (no date) (9), by Gisbert Palmié shows fair-headed peasants, farm workers, and children, engaged in all various forms of work. At the center of the painting is a goddess-like representation of the ideal German woman with her blonde hair and lean body type, typifying idealized Aryan traits. All look to her in reverence, for she represents a nation of peasants, a nation of pure Aryan stock. All those represented in the painting provide for her safe keeping and strength 
She embodies nature and the nations agriculture, she embodies the nation, she is Germania, the reason behind the nation's toil.

In Leopold Schmutzler's Farm Girls Returning from the Fields, (no date) (10), three young peasant women are coming in from the harvest. The expression on each woman's face is that of joy as is they know this is their proper place, in agriculture along the side of nature, and as Adam stated, the women depict the "playfulness" of nature. The women represent the happiness that can only be attained through life in the country, life as a peasant.

Blessings of the Earth, (no date) (11), painted by Wolfgang Willrich shows the German woman in her proper environment. The blonde peasant woman is standing amongst a field of wheat. Her arm is stretched out as if she is motioning to the viewer, "this is the bounty of the earth, and I offer it to the nation." She is responsible for the harvest and its propagation to the nation. The German woman is also offering herself as part of the harvest as well.

Nazi ideology connected women with the nations agriculture, as natures care giver. Women were inherently connected to the blood and soil of the 
nation, due to their biological function of giving birth, and their belief in female stereotypes. Because of this, the German woman would be represented in nature and as part of nature.

\section{"Natürlich"}

There were also a large number of commissioned paintings which represented women as nature itself. Although the Nazis believed that woman's main link with nature was through childbirth, the innate being of women was believed to be like that of nature, playful, emotional, innocent, something easily dominated. The depiction of women as nature is subtle yet widely used. In Wilhelm Hempfing's Summer, (no date) (12), a peasant woman is reclining in a field of wheat. Her shirt slightly open, her head tossed back in a position of sexual acceptance, the message, perhaps being that of playful abandon, awaiting a lover. The message is that woman is happiest in nature. In Richard Heymann's Ripe Fruit, (no date) (13), the blatant title is representative of the subject matter. In this painting a woman is surrounded by ripe fruit trees, she herself is picking. Although she is fully clothed, her breasts are highlighted through her blouse. Obviously, the 
connection between the woman and nature, ripe and fertile, is being made. Like the fruit trees, the woman too is "ripe" for the harvest as well.

In Johann Vinzenz Cissarz' Time of Ripeness, (no date) (14), a peasant man and woman are sitting together equally in the center of the painting. As the title says, this is a time of ripeness for this model peasant couple. The man looks as if he had just finished bringing in the harvest, the woman has a baby in her arms. Their faces are shadowed as if this could be any couple in Germany. Yet the connection is being made between nature and the woman's body. The earth is ripe with abundance as well as the woman's body. The Three Graces, (no date) (15), is a painting by Ernst Liebermann. There are three nudes in this painting each of which shows the female form in a different position. Twining around each female is wrapped in a wreath of flowers and greens whilst behind them the same flowers exist on the background. The message is, that women belong in nature because they are nature. The Woman is to be at peace in nature. This painting will be examined for its properties pertaining to the dominated woman as well.

The depiction of women as nature is justified 
through woman's biological function. Like nature, woman gives life, and is fruit bearing. The Nazis connected women to nature for women were "emotional," supposedly playful like nature, and completely fertile. Women were seen as something easily dominated, nature had always been something which could being domirated by men. The female nude also functioned as a type of voyeuristic means of domination. The German woman was seen as something sexual, something which could be dominated sexually.

\section{"Gretchen"}

Ideals depicted primarily through the female nude and the Nazi worship of the mother is a far cry from the sexual objectivity of "Gretchen." This role expressed for the German woman is that of the subordinate female, dominated by male power, and solely the object of male desire. There have been theories explaining the reasons for such subject matter. McNichols-Webb states that the female nude functioned as a type of mental mistress.

She existed within, the eye and mind of the observer and she offered everything imaginable. She was always available...totally controllable. She behaved in a way that real women did not. ${ }^{140}$

Obviously, the female nude functioned in the

${ }^{140} \mathrm{McNichols-Webb}, \mathrm{p} .354$. 
traditional pornographical way. However, Berthold Hinz explains these images as a type of compensation for the alienated Nazi male, pushed aside due to war, capitalism, or other societal pressures. Hinz states that the German woman was physically and psychologically sacrificed into her own type of alienation, that of desirable object.

Women were forced into a role that robbed them of their solidarity with men (including their own husbands) and thus destroyed the possibility of solidarity for an entire oppressed population. Man as worker degraded to an object to be used in the realization of Nazi goals, regenerated his esteem by, in turn, making woman an object. ${ }^{141}$

Ernst Liebermann's Lonely Heights, (no date) (16), as well as Paul Mathias Padua's Leda and the Swan, (no date) (17), are only a few paintings which express this ideal. The character of Leda is a subject matter which had been painted time and time again through out the Nazi era. At times Leda is depicted lying next to a mountain lake or under a tree, always present however, is the swan. Paul Mathias Padua's version, Leda is actually being penetrated by the swan. Leda's domination by the swan could represent the dominion of man over woman. Yet just as powerful is the message of

${ }^{141} \mathrm{Hinz}, \mathrm{p} .149$. 
the relationship between woman and nature. Obviously, viewers would have different reactions, women could model themselves after the shapely Nordic beauty and men could own the imagery of her female form. The Three Graces, (no date) (18, see pg.131), displays the female form in various positions, giving the male viewer the full view of the gracious female form. The voyeuristic tendencies these images evoke no doubt gave male viewers the feeling of superiority for it was woman's job to internalize men's desires, to be the fantasy of men incarnate. She was to be healthy, purely Aryan, virginal, young and absolutely undemanding to the point of self-sacrifice. The German woman, positioning her body for display, would be sacrificing her identity and her sexuality to the German male. It was these images of Woman that were needed to satisfy the displaced Nazi male ravaged by war and denied a political voice.

The image of mother did not become obsolete, Hinz discusses, however, when war came the image of woman needed to function differently, yet the image is that of servitude nonetheless. The woman depicted in Nazi art would function however the Reich needed her at the time. The iconography commissioned by the government 
sanctioned sexual domination and it was a visualization created by men for men.

The painting The Judgement of Paris can be used to demonstrate effectively the evolution of Nazi art. Three goddesses, Hera, Athena, and Aphrodite all claim to be the most beautiful. The Trojan prince Paris was chosen as judge. Each goddess promised Paris a gift if they were the chosen beauty. Paris ultimately chose Aphrodite as the most beautiful for she promised Paris the most beautiful woman, Helen of Troy. In this sense, Aphrodite was chosen because of the "value" of her "gift" to Paris. In Anselm Feuerbach's Judgment of Paris, (19) painted in 1870, the three goddesses are focused on the prize of the golden apple for whomever is the most beautiful. Paris' role is that of judge. Subsequently, Nazi painter's corrupted the myth further. Increasingly Paris' role as judge becomes that of observer, and Paris himself becomes the object of desire. In Adolf Ziegler's 1939 (20) rendition, the goddesses hope to please Paris' desires as a man, and Paris' role is changed to that of observer. The figure of Paris is shaded while the body parts of the goddesses are highlighted. In this painting the emphasis is on the seductiveness of the female and such seductiveness 
will play greater role in nude painting's during the later years of the regime.

The painting Diana at Rest 1939-40, (21), portrays the goddess Diana lounging against the backdrop of a German landscape. The artist Ivo Saliger has highlighted the breast and the pubic regions of Diana while her face is turned to profile without any sort of illumination. While Diana is laid out before the viewer, the focus is on her body parts, not the subject of Diana in her totality.

The same is true for Ernst Liebermann's The Slave, (no date) (22). The naked slave girl is placed in the center of the painting. She is somewhat cloaked over the pubic region yet her breasts are displayed prominently and highlighted. Again, the anonymous slave girl has her face looking forward, engaging the viewer. The emphasis is not the girl in her totality, but the objectification of what her body has to offer the Nazi male viewer.

Yet another painting entitled Expectation, (no date) (23) by Johann Schult also aims to titillate the male viewer. There are two female nudes, again surrounded by lush landscape, waiting for their respective lovers. One nude, her head again in profile, 
has her eyes looking downward expressing her submissiveness. Sitting beside her another young woman has her arms up behind her head, allowing her body to be in full view. She is looking over her shoulder waiting with "expectation" for her lover, to whom she will give of herself totally. If a woman is painted with her face to the side in profile, it was as if the viewer is looking into a private world, almost evoking a feeling of trespassing on a private moment. However, if she has her face turned forward, it was an entirely different matter. She is engaging the viewer, as if they are being invited into her realm.

In Ernst Liebermann's painting entitled By the Water, (no date) (24), three nudes are reclining by the water, each is positioned so the viewer can see the female form in various positions. The women look as is they might be the same woman for it is not their faces which are highlighted but their bodies. Again, the women's faces are in profile and shaded whilst area's around the breasts and buttocks are illuminated. Again, the message relayed is one of the female body as something to have, something to be observed and dominated.

The representation of woman as sexual object, as 
something to be dominated, was in fact a popular subject for painters under the Third Reich. As was discussed before, if woman was represented as the sexual, she could be dominated sexually. Women were represented as the woman-child as well, something which could be easily controlled. The German woman would be denied autonomy as an adult and would be represented as something innocent, naive, something which needed protection from her male counterpart.

\section{"Woman-child"}

The last category of the domination of women expressed in Nazi art is the image of the German woman as that of the woman-child. The German woman was represented as commodity, a pleasurable item to be protected and used. Yet this is also expressed through the denial of woman as an autonomous adult, as the "forever-child," the innocent.

The Nazi concept of paternity would ultimately reduce the status of the German woman to that of "childbride."142 Women's subordination in Nazi society created a child-like role for the female. This too can be connected with the ideals of "ownership" propagated by

${ }^{142}$ The denial of the German woman as autonomous adult, or the characterizing of woman as adolescent. Found in McNichols- Webb, p.354. 
Nazi ideology. In fact, reflecting this sentiment, many German men placed personals in local newspapers looking for their own child-bride.

She was to be purely virginal, Aryan, and usually wanted penniless with an eagerness to create male children (or Pflichterfüllung ${ }^{143}$ as Hitler referred to the duty of women to sacrifice for the community.) Hitler stated that while the "struggles of the males for the female grants the right or opportunity to propagate only to the healthiest."144 The most valuable characteristic of woman is that of maid or servant. Because man's duty to the Reich would be filled, she nonetheless must fulfill hers to him.

Sepp Hilz' Peasant Bride, (no date) (25) typifies the importance placed on the woman-child. In this painting, the young bride's eyes are turned down in submissiveness. She holds in her hand a bouquet of wedding flowers, clutching them closely to her bosom. She looks as if she is cherishing the thought of her husband and her place next to him as his bride. Her face has an angelic quality, an innocence with a rosy pallor. Behind her, a picture of the Virgin Mary, the

${ }^{143}$ Adolf Hitler, Mein Kampf (Boston: Houghton Mifflin Company, 1943), p.298. Translated by Ralph Manheim. ${ }^{144}$ Adolf Hitler, Ibid., p. 285. 
"blessed mother," no doubt a future role model for this young bride, although there is no doubt that she will not remain a virgin.

In Wilhelm Hempfing's Youth, (no date) (26), there are two young women, lying naked, looking as if they are engaged in conversation. Each girl is positioned, however to allow highlighted areas of her body to be turned out towards the viewer. The girls represent the future fertility of the nation. The innocent maidens are showing themselves ready to be women. Their bodies are displayed for the viewer, they are ready to be "molded," to become adult sexual beings, yet these two girls represent the epitome of what the German man wants at the time of marriage, a sweet innocent, virginal peasant girl.

Ultimately, these images of the German woman as mother, sexual object, something to be dominated, did parallel the ideology pertaining to the German woman. Politically, women were banished from the Third Reich, yet their important role within the state was in fact political. All of these painting's have a voyeuristic quality inherent within them. Even the political image of the mother, as well as the nude provide the viewer with the feeling that they are intruding into another 
realm, the realm of the erotic.

The link between politics and art can be understood through the study of the portrayal of women in official art. Women were depicted as the mother, connected and embodying nature, as the pert libertine, and as the forever adolescent-the women-child. Nazi hopes of women accepting their realm of domesticity and the erotic, are obviously blatant considering that the number of nudes created under the Reich far surpass any other western society of the twentieth century. Nonetheless, the success of the Nazi political dynamic depended upon every man, woman, and child, doing their duty for the good of the nation. Nazi Political art made it clear that being a mother, a loving wife, and propagating racially pure generations, were the German woman's only contributions to the Reich. 


\section{CHAPTER 5}

\section{Conclusion}

The first question asked regarding political art seems to be whether or not political art serves a function. The Third Reich operated under the assumption that art created for political use did serve a function: It served government ideology. However, Nazi art represented life under the regime in a symbiotic manner. It was the visual depiction of German society at its potential zenith. Nazi art represented the "ideal," and also a visual means in which to find the "ideal." On the other hand, Nazi art did depict the actuality of german society and Nazi ideology. It mirrored the violence, the misogyny, the racism. It reflected the dominance of the male force within Nazi society as well as the "non-political" figure of the German woman although her "non-political" role was in fact political, nonetheless, it depicted the importance of war and struggle as the creative dynamic behind the "ideal."

The mass aesthetic created during the Nazi era tells us how important the politicized image was to the state. The greatness of the Nazi state was upon the creation of a superior culture. Yet what the Nazis 
loathed about art created for the sake of the individual propagated Nazi art itself. The subject matter of Nazi art and the impetus behind its creation was the product of a few individual minds. An "elitist" few were responsible for the creation of an aesthetic for the masses.

Nazi political art was used by the state for its political and social validation. The art represented the political fervor of the political state, the dynamic behind National Socialism itself. If art was the highest representation of societal accomplishment, Nazi art would be the highest representation of the dictatorial system and its achievements. Art was the embodiment of the state's reality as well as the depiction of the state's validity. Ultimately, the state was legitimized through channels of political art.

Political art provided the National Socialist regime with a sense of history, a place within German history itself. A quote by Hitler highlighted this sentiment. Hitler compares the modern day Reich to the previous nations of German history.

Early Germanic history introduces our lofty theme. In the wake of a golden Viking ship the centuries roll by. Germanic warriors, Germanic women, Germanic priests and seers pass before us.... Even these mere imitations of mighty symbols draw from the mythical world of our 
ancestors have the power to overwhelm our modern sensibility. ${ }^{145}$

Hitler believed the place created for National Socialism within German history is connected with what he equates as German historical "greatness." Nazi Germany will reach its historical pinnacle for it is destined to do so, simply by the connection with Germany's "great" forbearers. The zenith of the Nazi state as well as its validation would be defined in terms of the state's connection with the past. There would be space created for Nazi Germany within German history itself:

In the shadow of their sword, Düver, Holbein, and Kranach (sic) created their works of art for the German people. Are they not brothers, the artists and soldiers? Tableaux from the High Baroque...the classic, and the romantic periods are followed by the modern age, our age. ${ }^{146}$

Clearly establishing a link between the Nazi Reich and the past legitimized the state historically, giving the nation a "sense of time and space," within world history, art also served yet another function. For the Nazis art was to be the pictorial representation of "authentic" German characteristics, and innate "virtues" which were to have supposedly been lost through the

${ }^{145}$ Printed in the Völkischer Beobachter. July 19, 1937. Found in Berthold Hinz, Art in the Third Reich (New York; Pantheon Books, 1979) Translated by Robert and Rita Kimber, p.2.

${ }^{146}$ Ibid. , pp. 4-5. 
onslaught of modernity. Political art provided the means by which the National Socialist state could recreate its identity, "rediscover" its innate characteristics. Political art represented the nations past, present and future, it provided the connection between past and present. Political art would be used to create a collective consciousness, to create a new historical cohesiveness amongst the people.

National Socialist art was to represent the German nation as it had always existed, metaphysically as well as in actuality. It was to depict the unity of the German nation historically. But as we know, the art of the Third Reich was complemented by the uniforms, the arm bands, the rallies. All elements of the Nazi aesthetic provided a sense national unity. These images were intended to "mobilize" the masses into a collective identity.

Nazi art also depicted the "simplicity of life" under National Socialism in which every member of the nation adhered to their sex-defined roles within the socially stratified society. Unity of the nation was dependent upon the "duty" of each individual fighting their own "battle" for the good of the Reich. For example, unity of the nation would be created and 
maintained if women accepted their role as child bearer and as the "mother of the Nation." Men were to be the workers, the soldiers, and the protectors of this nation. Provided each member did his or her "duty" for the Reich, the Volksgemeinschaft would flourish.

Woman's connection to the state was important considering what lengths the National Socialist went in assuring she would become the "eternal mother," and the propagator of the future Volk. To give woman back her "lost virtues" was the reasoning behind it all. However one must not forget that the dominance of male power absolutely depended upon the German Woman accepting her role as the "second sex," as historian Claudia Koonz has written. ${ }^{147}$ Women were to accept the space in society the Nazis had created, they would have to find the means of emotional "survival" within their own "little" sphere as Nazi officials had coined it, and in doing so she would have to accept life in terms of "faith and beauty." Ultimately Nazi art provided the people with a visual representation of the "ideal" German woman, man and child providing the message that the ideal could be obtained, and the contribution of the people would be determined by his or her gender.

${ }^{147}$ Koonz, p. 177 
An important function of Nazi political art, besides acting as a form of documentary, lay in the masking of the Reich's contradictory reality. The elements of Nazi art, "Strength and Beauty," "Blut und Boden," were absolutely imperative to the creation of a realm of "normalcy" with Nazi society itself. Art would mask with "beauty" that which was ugly. The portrayal of the peaceful peasant life, a unified Volk was a stark contrast to the struggle between the races and the preparation for war. Would the public look past the violence of German society in hopes of reaching the pictorial "ideal" represented in Nazi paintings. The nation was provided with a visual end to a violent means. Did the Nazi hierarchy believe if they provided the German people with the grand illusion of a "great" culture, the people would accept the machine of terror which surrounded them? Nonetheless, the "beauty" and "peace" created within the realm of Nazi political art would in fact be a far cry from the actual world of brutality and hatred. 


\section{BIBLIOGRAPHY}

Adam, Peter. Art of the Third Reich. New York: Harry N. Abrams, Inc., Publishers, 1992.

Allen, William Sheridan. The Nazi Seizure of Power, The Experience of a Single German Town 1930-1935.

Chicago: Quadrangle Books, Inc., 1965.

Baynes, Norman $H$. The Speeches of Adolf Hitler, Vol 1. New York: Gordon Press, 1981.

Becker Lutz. "Aspects of Art of the Third Reich." The Romantic Spirit in German Art 1790-1990. London; Thames and Hudson, 1994. Edited by Keith Hartley, Henry Meyric Hughes, Peter-Klaus Schuster, William Vaughn. p. 390 .

Benton, Tim. "Rome Reclaims its Empire," Art and Power, Europe Under the Dictators $1930-1945$. London; Thames and Hudson, 1995. Compiled by Dawn Adens, Tim Benton, David Elliot, Simonetta Fraquelli, and Ian Boyd Whyte.

Bottai, Giuseppe. "In Defense of Modern Art," 1938. Art and Power, Europe Under the Dictators 19301945. London; Thames and Hudson, 1995. Compiled by

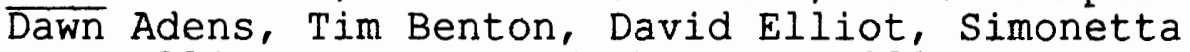
Eraquelli, and Ian Boyd Whyte, p. 181.

Brady, Robert. The Spirit and Structure of German Eascism. New York; The Citadel Press, 1971.

Braun, Emily (Editor). Italian Art in the 20th Century: Painting and Sculpture, 1900-1988. London; Prestel-Verlag, Munich, and Royal Academy of Arts, 1989. pp. 147 and 173 .

Bridenthal, Renate, Anita Grossman, and Marion Kaplan. When Biology Became Destiny. New York: Monthly Review Press, 1984.

Burleigh, Michael and Wolfgang Wippermann. The Racial State: Germany 1933-1945. Cambridge: Cambridge University Press, 1991.

Butler, R.D.D. The Roots of National Socialism 17831933. London: Faber and Faber, 1941. 
Cohen, Jean-Louis. "When Stalin Meets Haussman." The Moscow Plan of 1935. Art and Power, Europe under the Dictators 1930-1945. London: Thames and Hudson, 1995. Complied by Dawn Adens, Tim Benton, David Elliot, Simonetta Fraquelli, and Ian Boyd Whyte.

Collotti, Enzo and Riccardo Mariani. The Watercolours of Hitler; Recovered Art Works, Homage to Rodolfo Siviero. Florence: Eratelli Alinari Editrice, 1984.

Deuel, Wallace R. People Under Hitler. New York: Harcourt, Brace and Company, 1942.

Elliot, David. "A Life-and-Death Struggle." Art and Power, Europe Under the Dictators 1930-1945. London: Thames and Hudson, 1995. Compiled by Dawn Adens, Tim Benton, David Elliot, Simonetta Eraquelli, and Ian Boyd Whyte.

$$
\text { "Introduction." Art and Power, Europe }
$$
Under the Dictators 1930-19 45. Iondon: Thames and Hudson, 1995. Compiled by Dawn Adens, Tim Benton, David Elliot, Simonetta Eraquelli, and Ian Boyd Whyte.

Epstein, Klaus. The Genesis of German Conservatism. Princeton: Princeton University Press, 1966.

Evans, Richard J. "Feminism and Female Emancipation in Germany 1870-1945: Sources, Methods, and Problems of Research." Central European History. Vol. 1x. No. 4. Dec. 1976.

Fest, Joachim C. Hitler. New York: Harcourt Brace Jovanovich, Inc., 1974 .

- The Face of the Third Reich. New York: Pantheon Books, 1970 .

Eraquelli, Simonetta. "All Roads Lead to Rome." Art and Power, Europe Under the Dictators 1930-1945. London: Thames and Hudson, 1995. Compiled by Dawn Adens, Tim Benton, David Elliot, Simonetta Eraquelli, and Ian Boyd Whyte.

Frauen im Nationalsozialismus. Dokumente und Zeugnisse. Herausgegeben von Ute Benz. München: Verlag C.H. 
Beck, 1993.

Glaser, Hermann. The Cultural Roots of National

Socialism, Translated by Ernest A. Menze. Austin:

University of Texas Press, 1978. Originally

published in 1964 as Spiesser-Ideologie: Von der

Zerstörung des deutschen Geistes in 19. Und 20 .

Jahrhundert.

Goebbels, Josef. "Kunstkritik gesetzlich verankert." Lesen Darstellen Begreifen. Frankfurt am Main:

Hirschgraben-Verlag. No date, pp.36-7. "Nach Ihrer Machtergreifung 1933 hatten die Nationalsozialisten das gesamte Kulturleben regliementiert. Mit der folgenden Anordnung verbot der Propagandaminister Josef Goebbels 1936 jede Kunstkritik."

Grosshans, Henry. Hitler and the Artists. New York: Holmes and Meier Publishers, Inc., 1983.

Grunberger, Richard. The Twelve Year Reich. New York: Holt, Rinehart and Winston, 1971.

Heiden, Konrad. Der Fuehrer. Hitler's rise to power. Translated by Ralph Manheim. Boston: Houghton Mifflin Company, 1944.

Hinz, Berthold. Art in the Third Reich. Translated by Robert and Rita Kimber. New York: Random House Publishing, 1979.

"Degenerate and Authentic." Art and Power, Europe Under the Dictators 1930-1945.

London: Thames and Hudson, 1995. Compiled by Dawn Adens, Tim Benton, David Elliot, Simonetta Fraquelli, and Ian Boyd Whyte.

Hitler, Adolf. Peroration of the speech at the "Great German Art Exhibition, 1937, complied by John Willett under chapter titled "Contemporary Voices." Art and Power. Europe Under the Dictators 19301945. London: Thames and Hudson, 1995. Compiled by Dawn Adens, Tim Benton, David Elliot, Simonetta Eraquelli, and Ian Boyd Whyte.

- Mein Kampf. Translated by Ralph Manheim. Boston: Houghton Mifflin Company, 1943.

Hoffman, Linda Kay. An Historical Study of the 
Philosophy of Art and Art Education in Nazi Germany and Its Role in Mass Education. UMI: Boston University School for the Arts, 1976.

Hulten, Pontus and Germano Celanto. Italian Art 19001945. New York: Rizzoli: International Publications Inc., 1989.

Huber, Jay C. German Cultural History from 1860 to Present Day. Munich: Gmbit, Munich Printing, 1983.

Kershaw, Ian. Hitler. London and New York: Longman Publishing, 1991.

- The "Hitler Myth," Image and Reality in the Third Reich. Oxford: Oxford University Press, 1987 .

King, David B., Gordon A. Craig, David L. Gross, Vernon L. Lidtke, Charles E. McClelland, and Gary D. Stark. Essays on Culture and Society in Modern Germany. Arlington: University of Texas, 1982.

Koonz, Claudia. Mothers in the Fatherland, women the family and Nazi politics. New York: St. Martin's Press, 1987.

McNichols-Webb, Mary Alice. Art as Propaganda, Comparison of the Imagery and Roles of Women as depicted in German Expressionist, Italian Futurist, and National Socialist Art. U.M.I.: Ann Arbor, Michigan, 1989.

Meinecke, Friedrich. The German Catastrophe.

Translated by Sidney B. Fay. Boston: Beacon

Press, 1950.

Mosse, George L. Nazi Culture. Translations by Salvator Altanasio and others. New York: Grosset and Dunlap, 1974.

The Crisis of German Ideology. The
Intellectual origins of the Third Reich. New York:
Grosset and Dunlap, 1964.

The New York Times. New York: 1937. 16, 17 March; 15 June; 17, 18, 19, 20 July; 4, 5, 10, 12 August; 1,8 september. 
Nicholls, AJ. Weimar and the Rise of Hitler. Second Ed. New York: St. Martin's Press, 1979.

Noakes, J. and G. Pridham Editors. Nazism I. A History in Documents and Eyewitness Accounts 1919-1945.

New York: Schocken Book, 1984.

Norvold, James E. Time, Space, Dimension. Adolf Hitler and His relationship to Art. Domingez Hills:

California State Un., Spring 1990.

Owen, Francis. The Germanic People. Their Origin, Expansion and Culture. New Haven: College and University Press, 1966.

Remak, Joachim. The Nazi Years. A Documentary History. New York: Simon and Schuster, Inc., 1986.

Rose, Ramona M. The Position and Treatment of Women in Nazi Germany. As viewed from the perspective of the English Language Press - 1933-1945. Geographical series \#38. Vancouver: Tantalus Research Limited, 1984.

Rosenberg, Alfred. Revolution in der bildenden Kunst? München: F. Eher Nachf., 1934.

Rutherford, Ward. Hitler's Propaganda Machine. London: Bison Books, 1978 .

Sax, Benjamin and Dieter Kuntz. Inside Hitler's Germany. A Documentary History of Life in the Third Reich. Lexington: D.C. Heath and Company, 1992 .

Siegele-Wenschkewitz, Lenore and Gerda Stuchlik. Frauen und Faschimus in Europe Der Faschistische Körper. Pfaffenweiler: Centaurus-Verlagsgesellschaft, 1990 .

Speer, Albert. Inside the Third Reich. Translated by Richard and Clara Winston. New York: The MacMillian Company, 1970.

Steinweis, Alan E. Art, Ideology and Economics in Nazi Germany. University of North Carolina Press, 1993.

Stephenson, Jill. Women in Nazi Society. New York: Harper and Row Publishers, 1975. 
Stern, Fritz. The Politics of Cultural Despair. A Study in the Rise of Germanic Ideology. Berkeley, Los Angeles, London: The University of California Press, 1974 .

Taylor, Brandon. "Photo-Power." Art and Power, Europe under the Dictators 1930-1945. London: Thames and Hudson, 1995. Complied by Dawn Adens, Tim Benton, David Elliot, Simonetta Fraquelli, and Ian Boyd Whyte.

and Wilfried Van der Will. The

Nazification of Art, Design, Music, Architecture and Film in the Third Reich. Winchester: The Winchester Press, Winchester School of Art, 1990.

Tolischus, Otto D. They Wanted War. New York: Reynal and Hitchcock, 1940 .

Vedder-Shults, Nancy. Motherhood for the Fatherland. The Portrayal of women in Nazi Propaganda. U.M.I.: Ann Arbor: The University of Wisconsin-Madison, 1982 .

Viereck, Peter. Metapolitics From the Romantics to Hitler. New York: Alfred A. Knopf Inc., 1941.

Whyte, Ian Boyd. "National Socialism and Modernism." Art and Power, Europe Under the Dictators 19301945. London: Thames and Hudson, 1995. Compiled by Dawn Adens, Tim Benton, David Elliot, Simonetta Fraquelli, and Ian Boyd Whyte

Women under Fascism "Kirche, Kinder, Küche." 1934. Prepared by the commission investigating fascist activities for the national committee to aid victims of German fascism. New York: New York Workers Library Publishers, 1934.

Worely, Linda K. "The Body, Beauty, and the Woman: The Ugly Heroine in stories by Theresa Huber and Gabriele Reuter." The German Quarterly. Vol.64. Summer 1991 No.3. 
APPENDIX

113 


\section{SOURCES OF ART}

Johann Vinzenz Cissarz. Time of Ripeness, oil on canvas, no date, "whereabouts unknown." Berthold Hinz, Art in the Third Reich. New York: Pantheon Books, 1979. p.132.

Karl Diebtsch. Mother, oil on canvas, no date, "whereabouts unknown." Berthold Hinz, Art in the Third Reich. New York: Pantheon Books, 1979. p.132.

Anselm Feuerbach. Judgement of Paris, oil on canvas, 1870, Hamburg, Kunsthalle. Berthold Hinz, Art in the Third Reich. New York: Pantheon Books, 1979 . p.152.

Constatntin Gerhardinger. Family Portrait, no date, "whereabouts unknown." Peter Adam, Art of the Third Reich. New York: Harry N. Abrams, Inc., Publishers, 1992. p.140.

-William Hempfing. Youth, oil on canvas, no date, "whereabouts unknown." Berthold Hinz, Art in the Third Reich. New York: Pantheon Books, 1979. p.144.

- Summer, oil on canvas, no date,

"whereabouts unknown." Berthold Hinz, Art in the Third Reich. New York: Pantheon Books, 1979. p.134.

Richard Heymann. In Good Hands, oil on canvas, no date, "whereabouts unknown." Berthold Hinz, Art in the Third Reich. New York: Pantheon Books, 1979. p.131.

- The Heir, oil on canvas, no date,

"whereabouts unknown." Berthold Hinz, Art in the Third Reich. New York: Pantheon Book, 1979. p.132. "whereabouts $\frac{\text { Ripe Fruit, oil on canvas, no date, }}{\text { unknown." Berthold Hinz, Art in the }}$ Third Reich. New York: Pantheon Books, 1979. p.133.

Sepp Hilz. Peasant Bride, oil on canvas, no date, "whereabouts unknown." Berthold Hinz, Art in the 
Third Reich. New York: Pantheon Books, 1979. p.133.

Ernst Liebermann. The Slave, oil on canvas, no date, "whereabouts unknown." Berthold Hinz, Art in the Third Reich. New York: Pantheon Books, 1979. p.139.

- Lonely Heights, oil on canvas, no date, "whereabouts unknown." Berthold Hinz, Art in the Third Reich. New York: Pantheon Books, 1979. p. 139 .

- The Three Graces, oil on canvas, no date, "whereabouts unknown." Berthold Hinz, Art in the Third Reich. New York: Pantheon Books, 1979. p.143.

- By the Water, oil on canvas, no date, "whereabouts unknown." Peter Adam, Art of the Third Reich. New York: Harry N. Abrams., Publishers, 1992. p.64.

Paul Mathias Padua. Leda and the Swan, oil on canvas, no date, "whereabouts unknown." Peter Adam, Art of the Third Reich. New York: Harry N. Abrams Inc., Publishers, 1992 . p.155.

Gisbert Palmie. Reward of Work, oil on canvas, no date, "whereabouts unknown." Peter Adam, Art of the Third Reich. New York: Harry N. Abrams Inc., Publishers, 1992. p.142.

- Arthur Ressel. Expectant Mother, oil on canvas, no date, "whereabouts unknown." Berthold Hinz, Art in the Third Reich. New York: Pantheon Books, 1979. p.131.

Ivo Saliger. Diana's Rest, oil on canvas, 1939-40, "whereabouts unknown." Peter Adam, Art of the Third Reich. New York: Harry N. Abrams Inc., Publishers, 1992. p.233.

Hans Schmitz-Wiendenbrück. Nation at War, oil on canvas, no date, "whereabouts unknown." Berthold Hinz, Art in the Third Reich. New York: Pantheon Books, 1979. p.127. 
Johann Schult. Expectation, oil on canvas, no date, "whereabouts unknown." Berthold Hinz, Art in the Third Reich. New York: Panthoen Books, 1979 . p.142.

Jürgen Wegner. Thanksgiving, oil on canvas, 1943, "whereabouts unknown." Berthold Hinz, Art in the Third Reich. New York: Pantheon Books, 1979. p.149.

Wolfgang Willrich. Blessings of the Earth, oil on canvas, no date, "whereabouts unknown." Berthold Hinz, Art in the Third Reich. New York: Pantheon Books, 1979. p.134.

Adolf Wissel. Farm Family from Kahlenberg, oil on Canvas, 1939, "whereabouts unknown." Peter Adam, Art of the Third Reich. New York: Harry N. Abrams Inc., Publishers, 1992. p.148.

Adolf Ziegler. Judgement of Paris, oil on canvas, no date, "whereabouts unknown." Berthold Hinz, Art in the Third Reich. New York: Pantheon Books, 1979. p.138. 


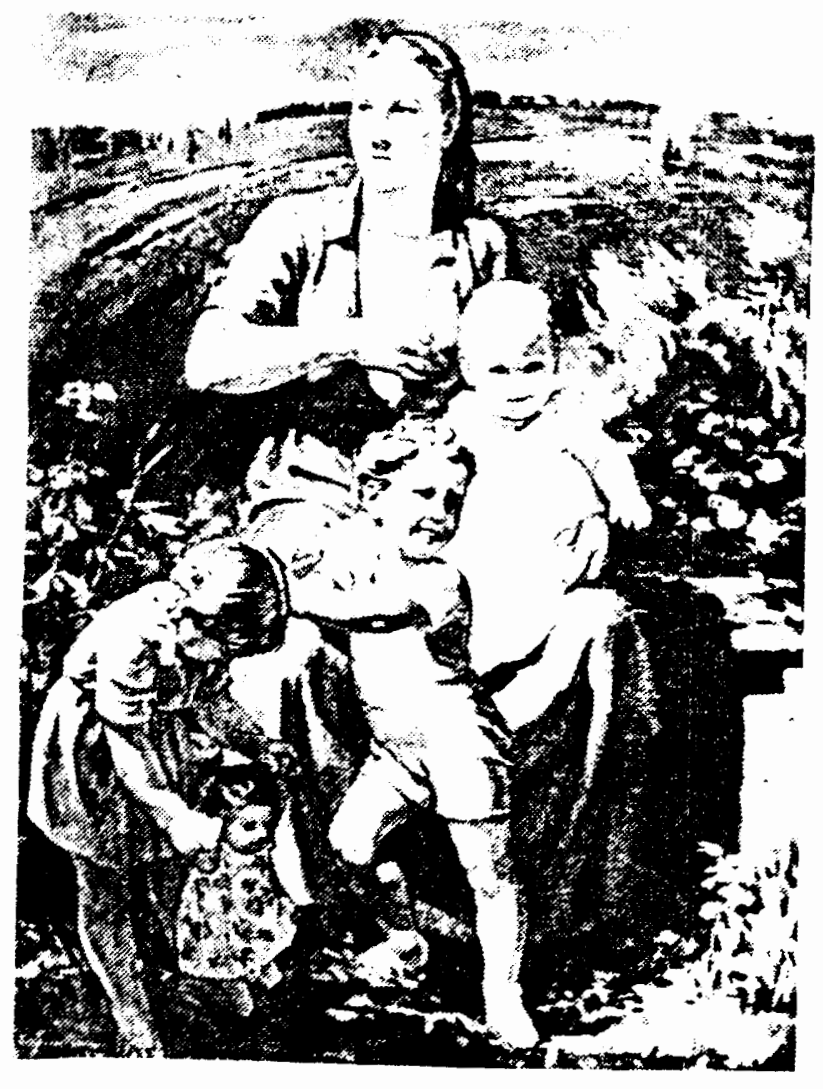

(1) Richard Heymann's, In Good Hands, (no date) 


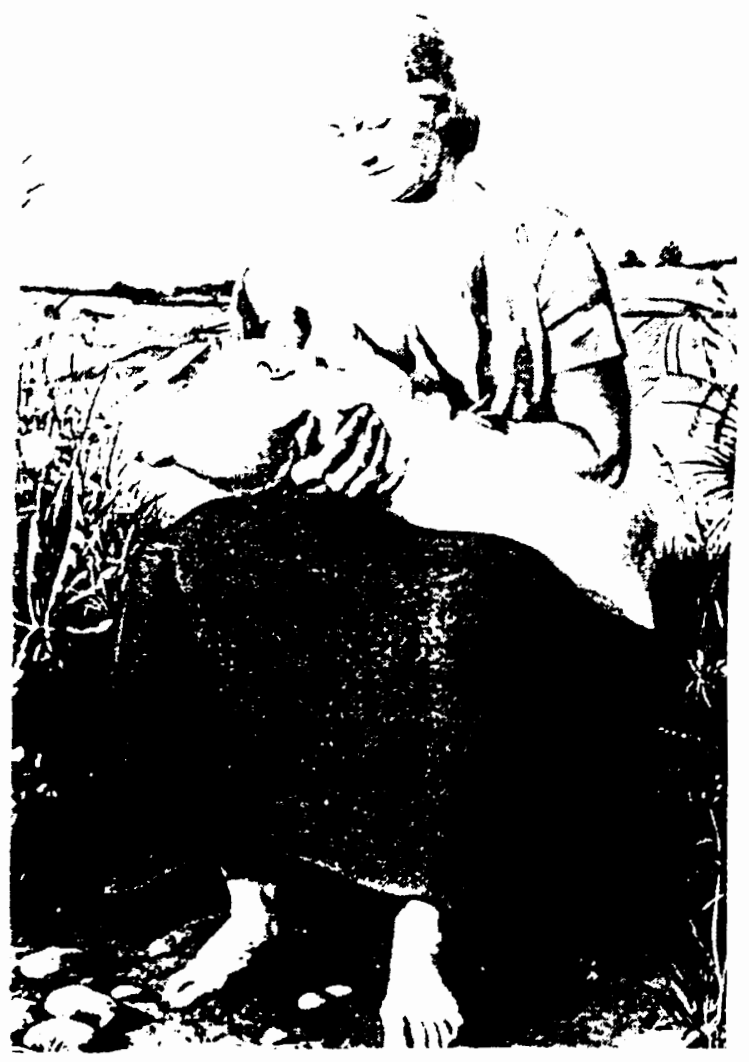

(2) Karl Diebitsch's, Mother, (no date) 


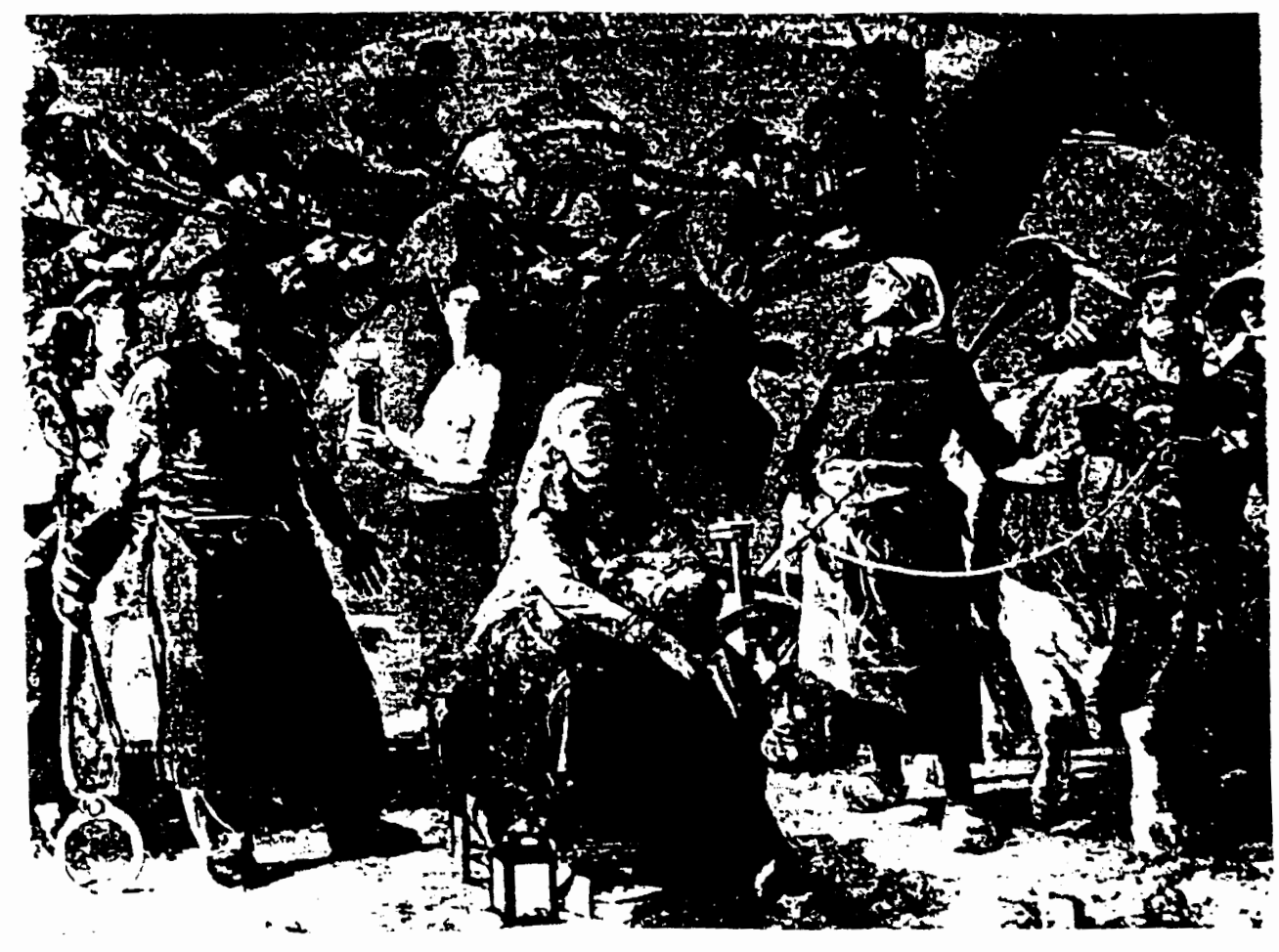

(3) Hans Schmitz-Wiedenbruck's Nation at War, (no date) 


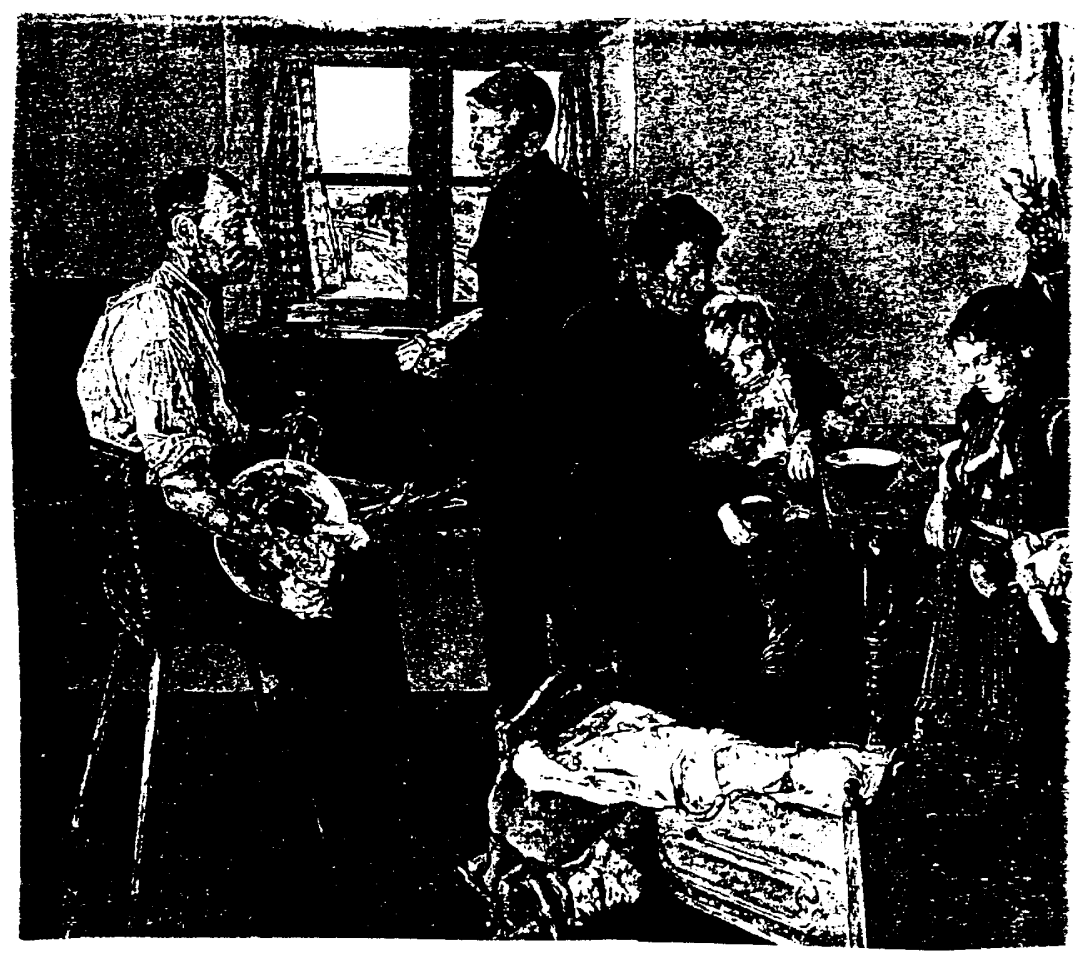

(4) Constantin Gerhardinger's, Family Portrait, (no date) 


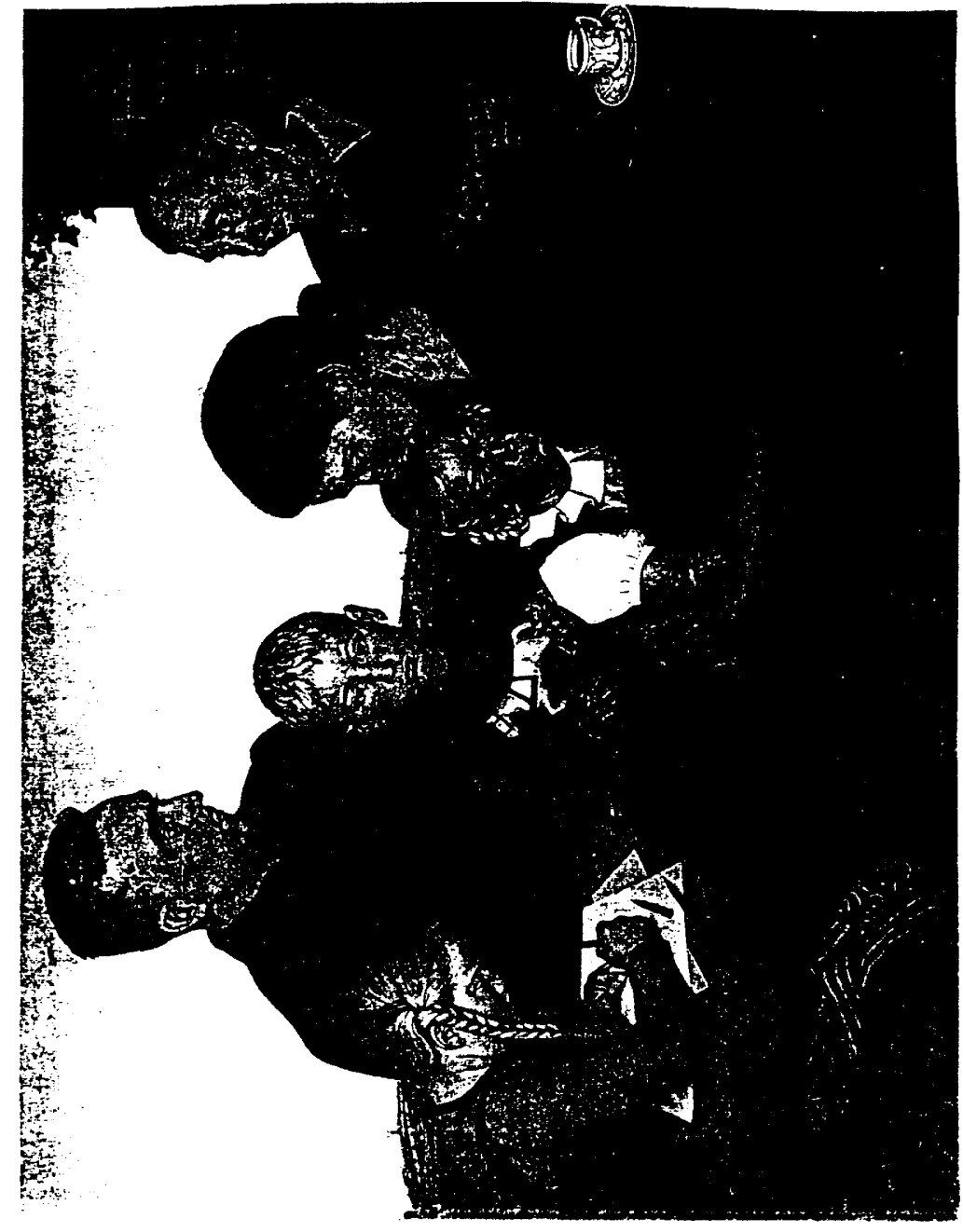

(5) Adolf Wissel's, Farm Family from Kahlenburg, 1939 


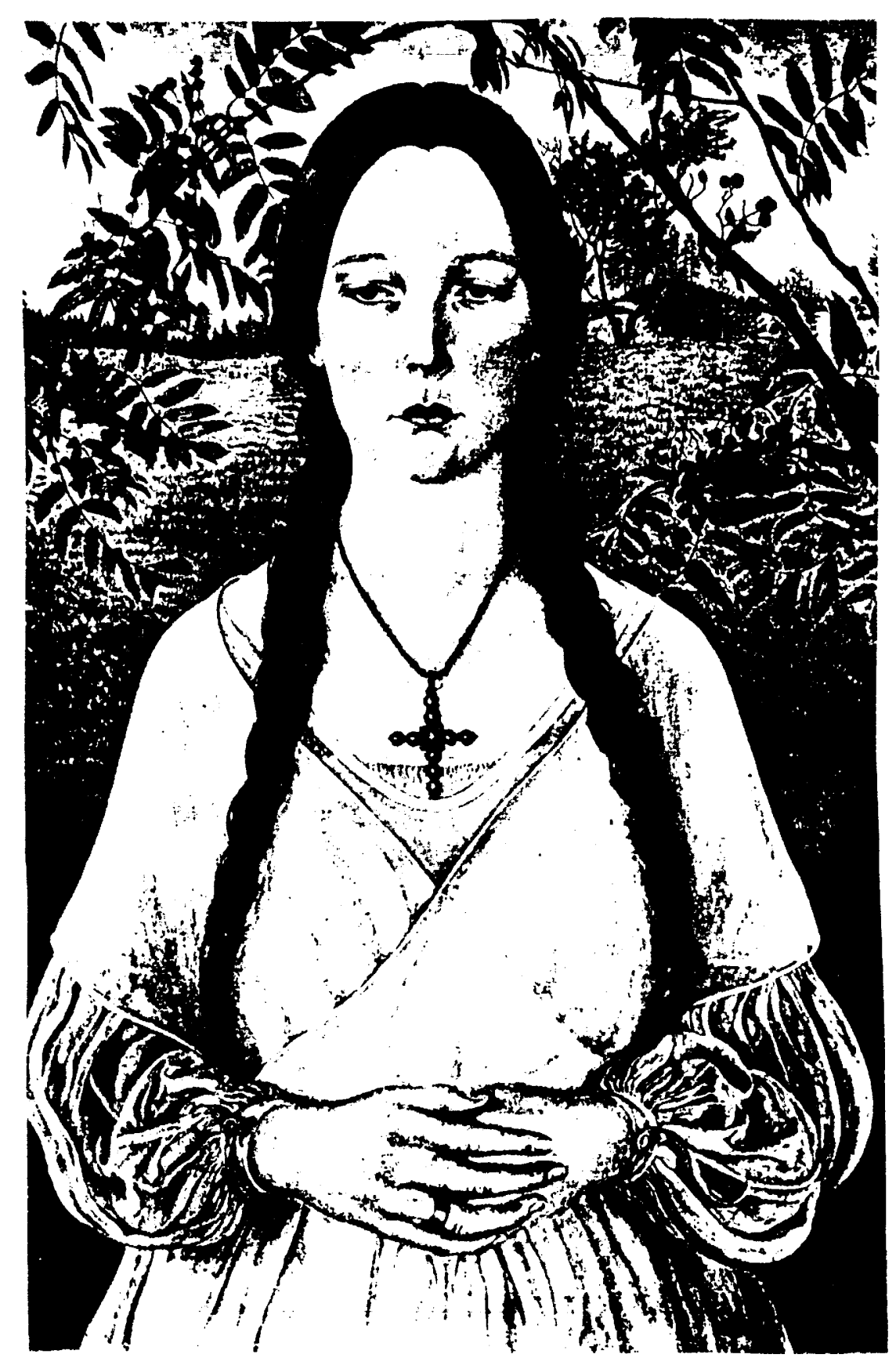

(6) Arthur Ressel's, Expectant Mother, (no date) 


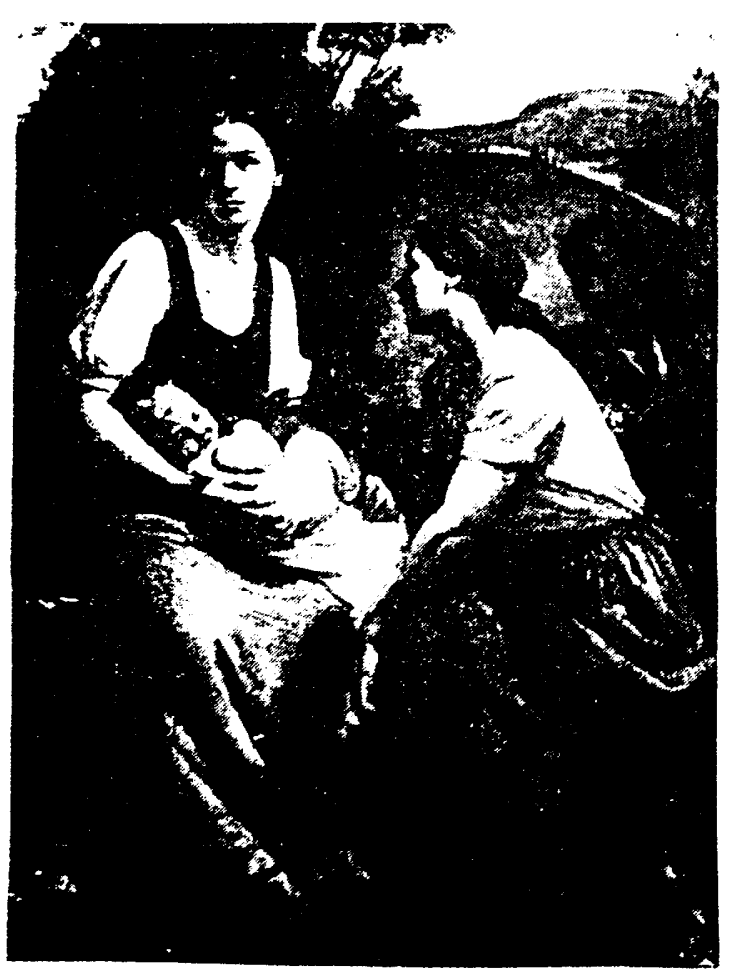

(7) Richard Heymann's, The Heir, (no date) 


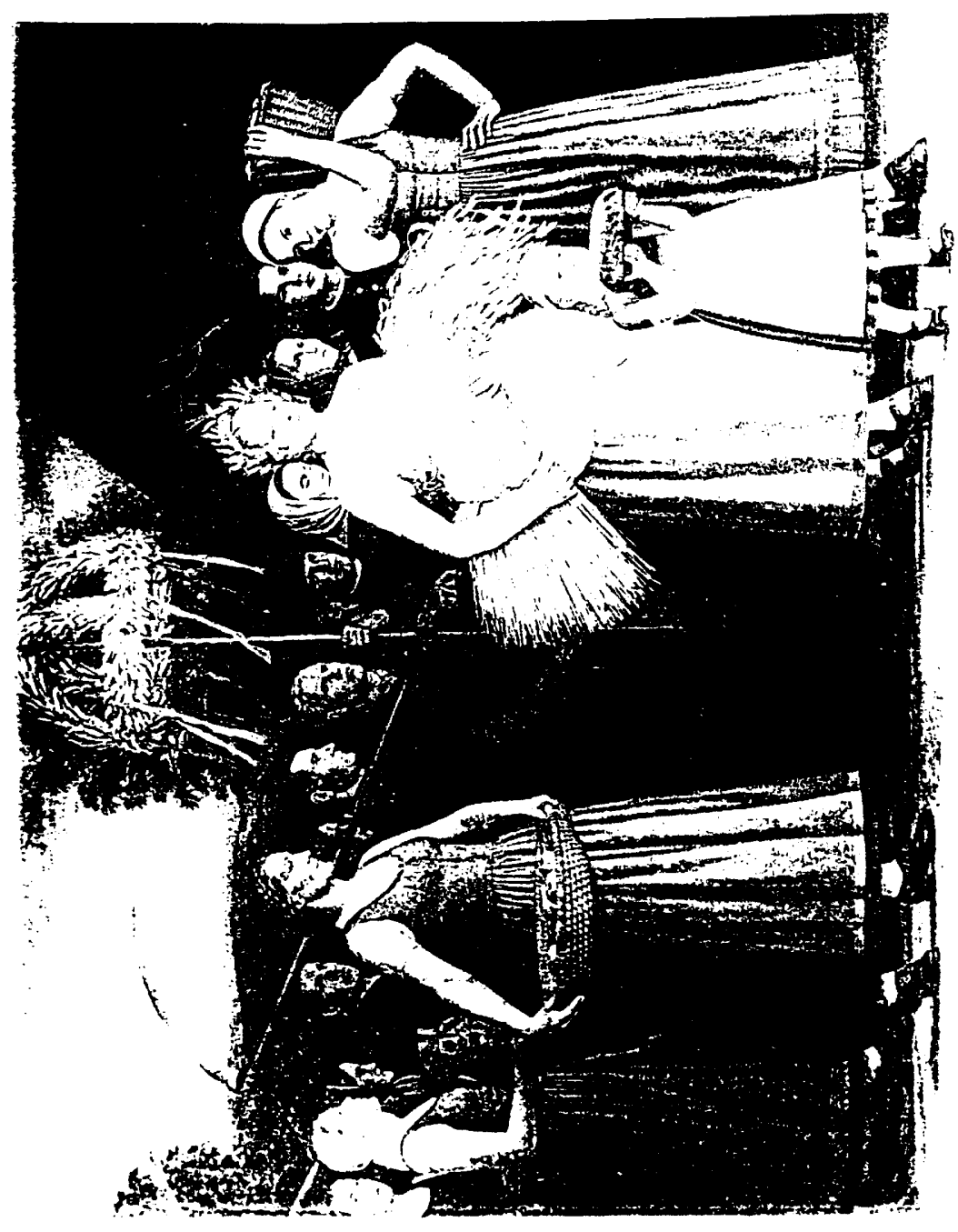

(8) Jürgen Wegener's, Thanksgiving, 1943 


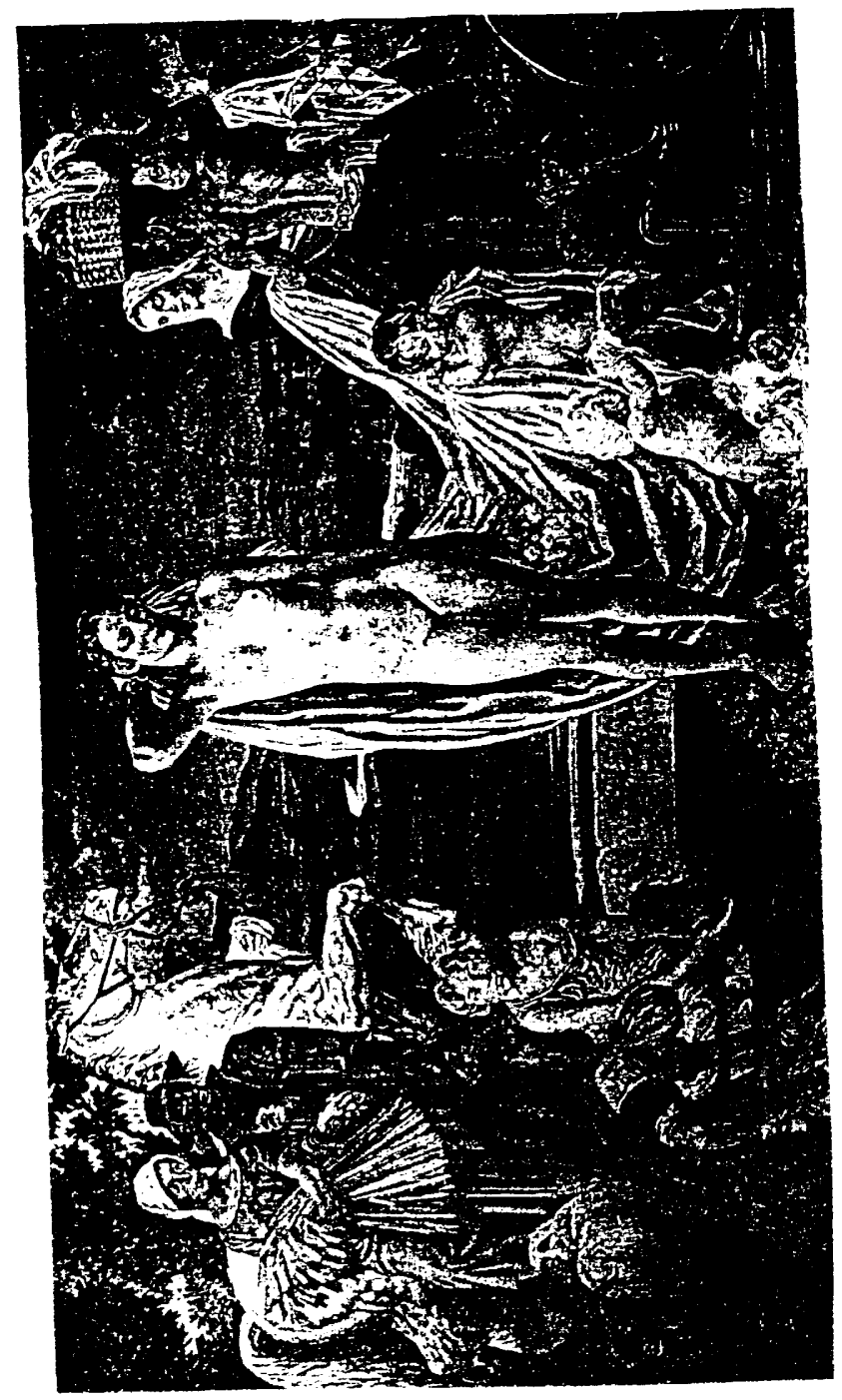

(9) Gisbert Palmié's, Rewards of Work, (no date) 


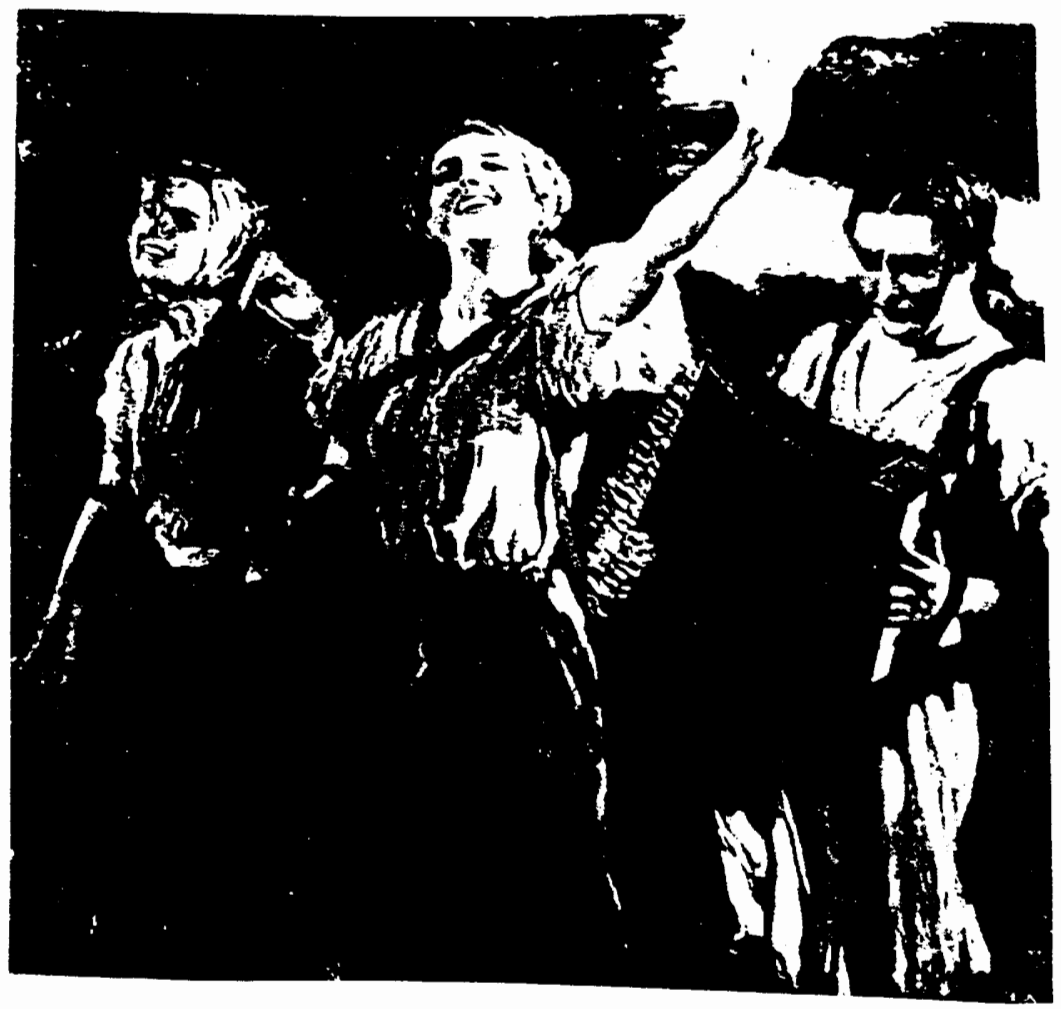

(10) Leopold Schmutzler's, Farm Girls Returning from the Fields, (no date) 


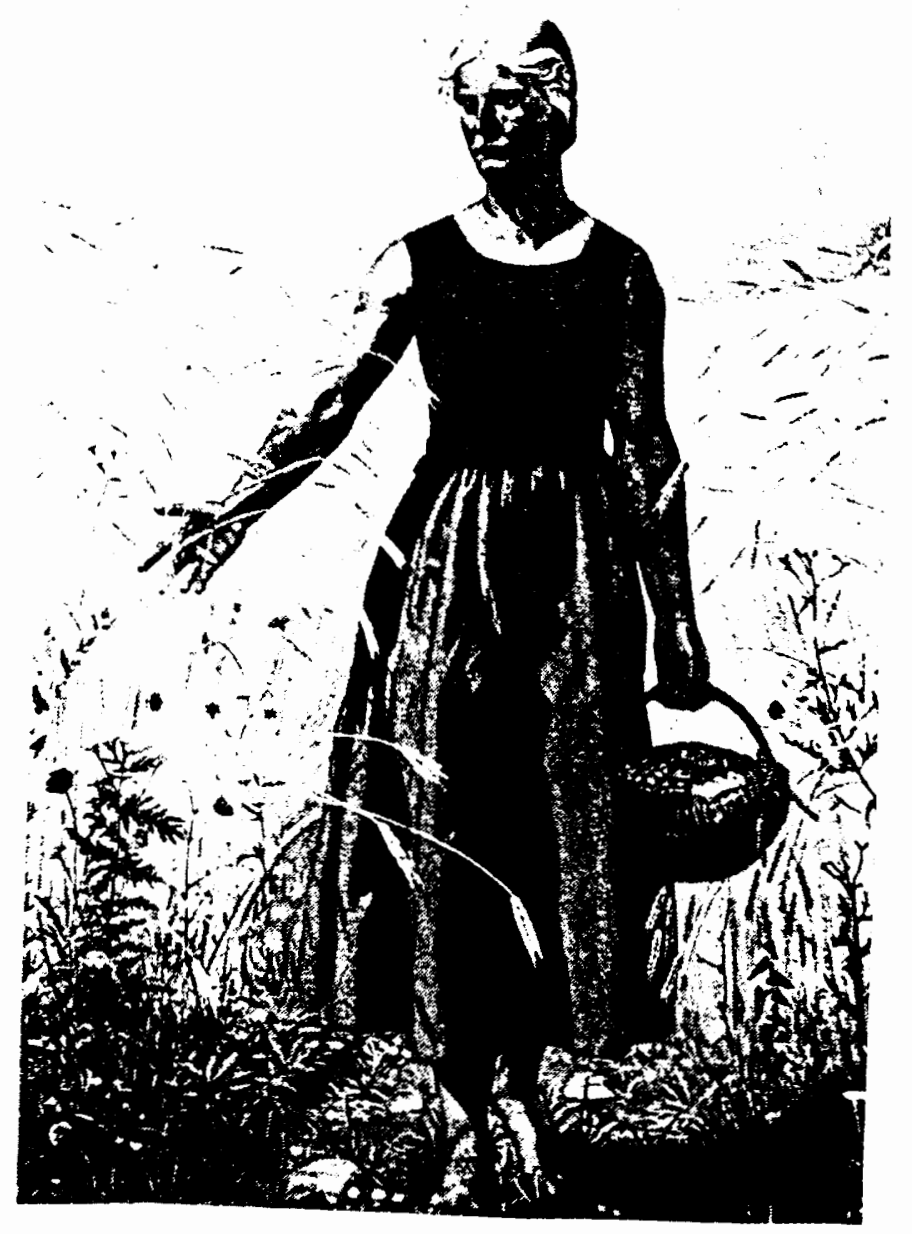

(11) Wolfgang Willrich's, Blessings of the Earth, (no date) 


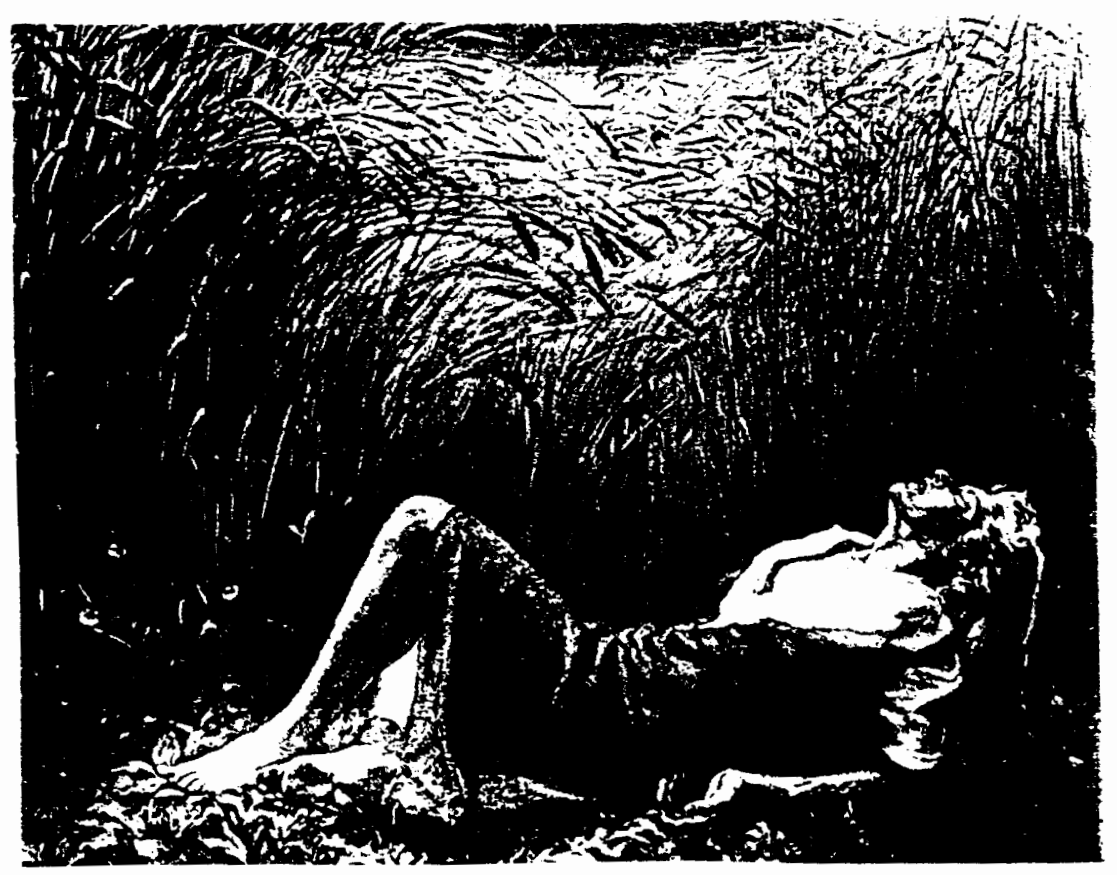

(12) Wihelm Hempfing's, Summer, (no date) 


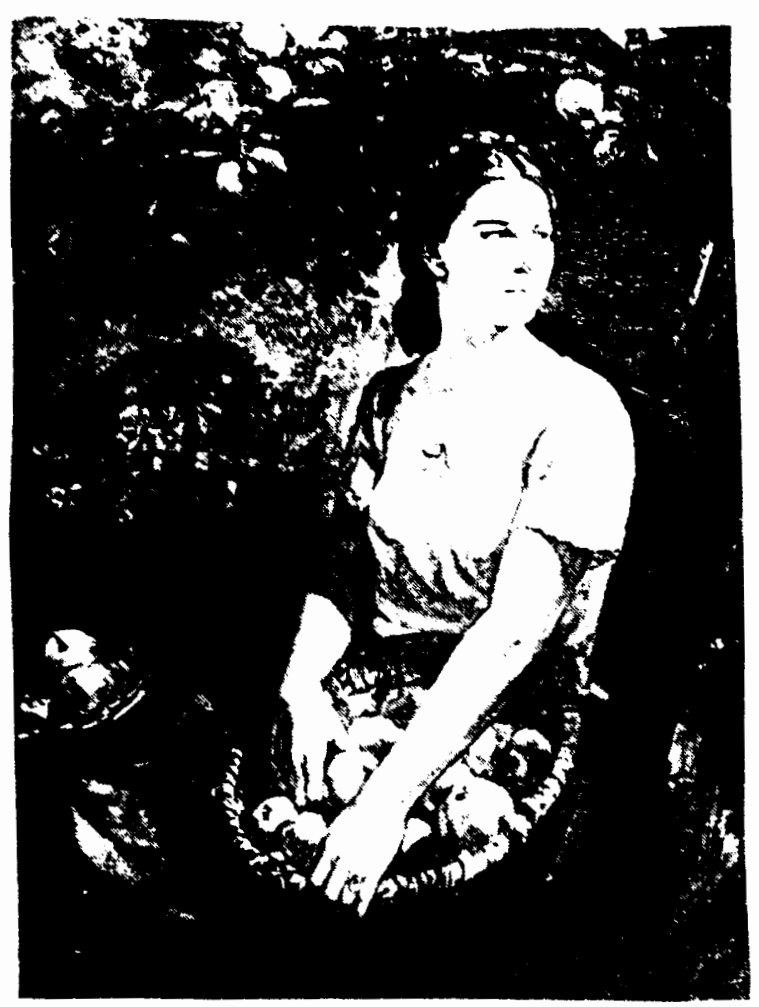

(13) Richard Heymann's, Ripe Fruit, (no date) 


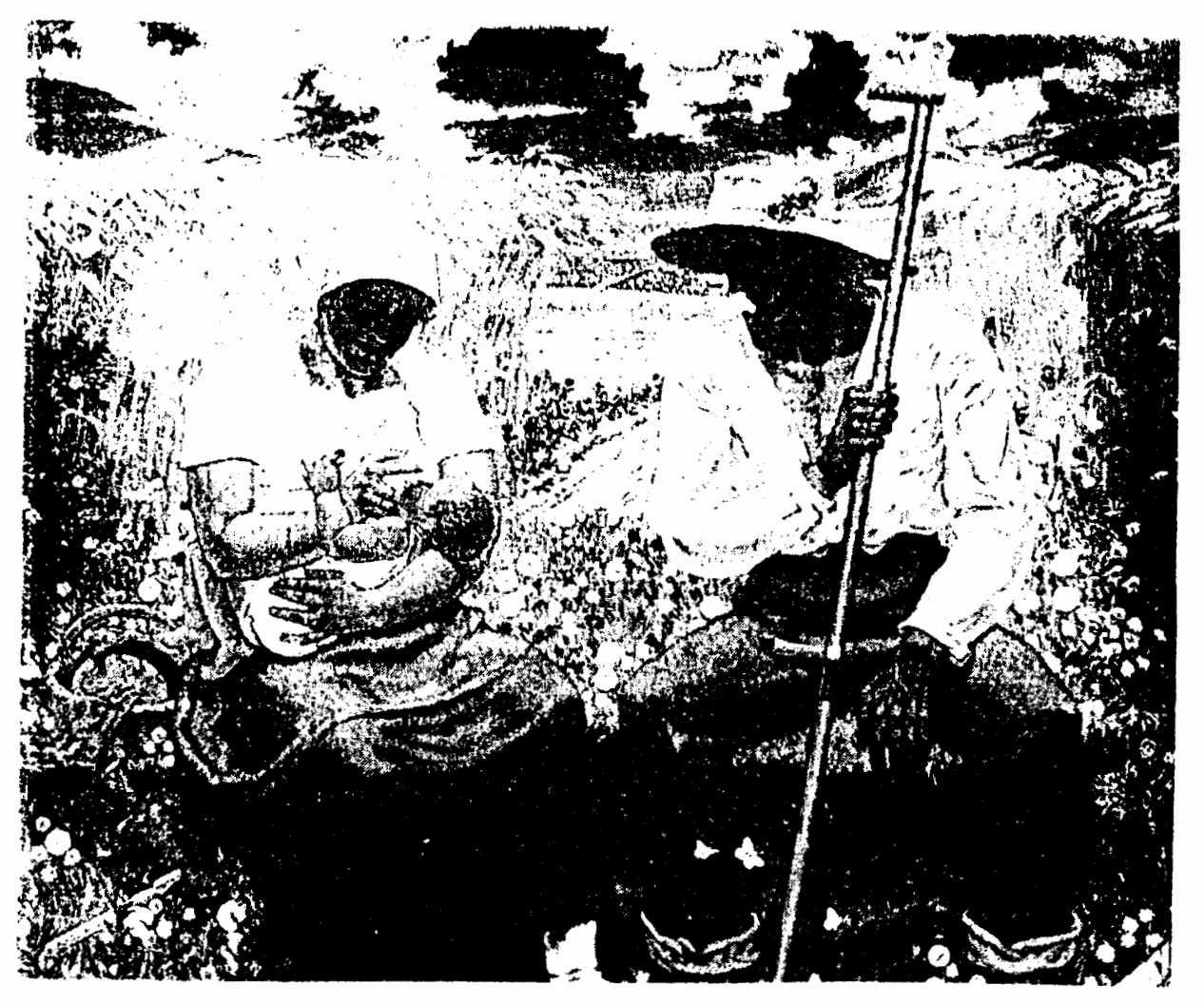

(14) Johann Vinzenz Cissarz', Time of Ripeness, (no date) 


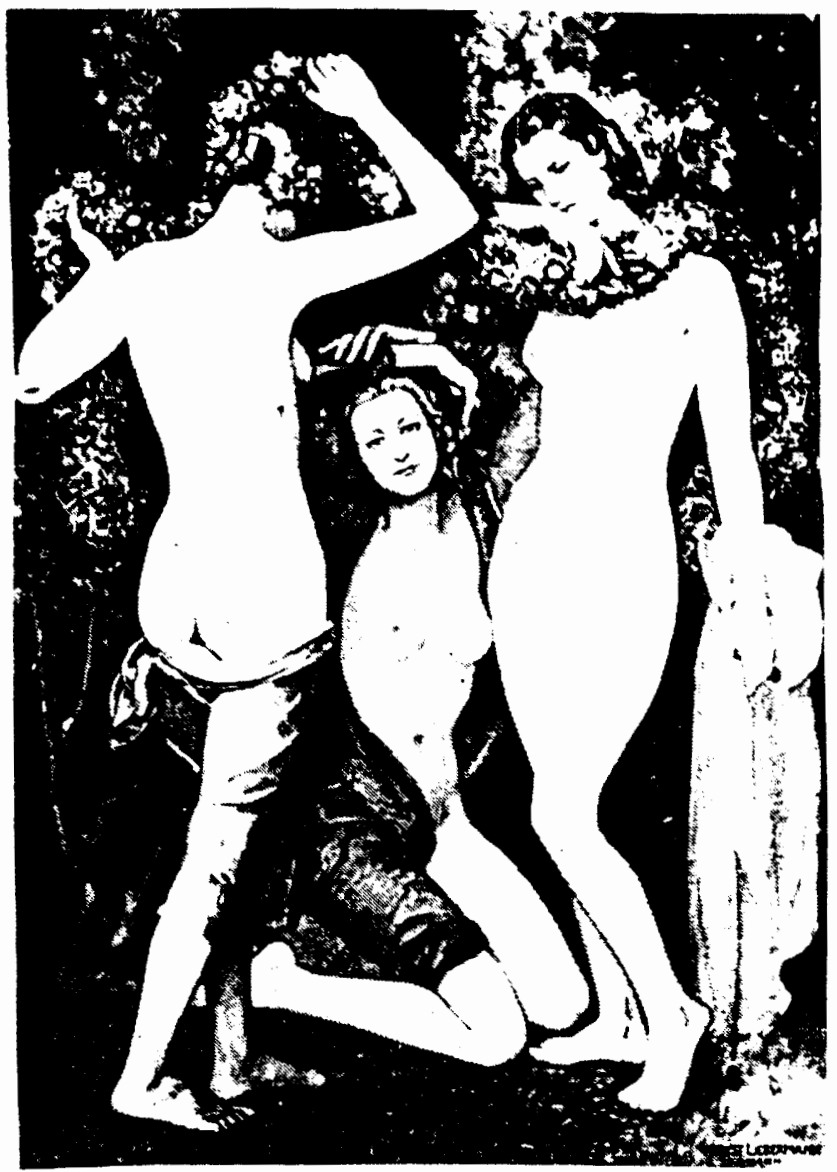

(15) Ernst Liebermann's, The Three Graces, (no date) 


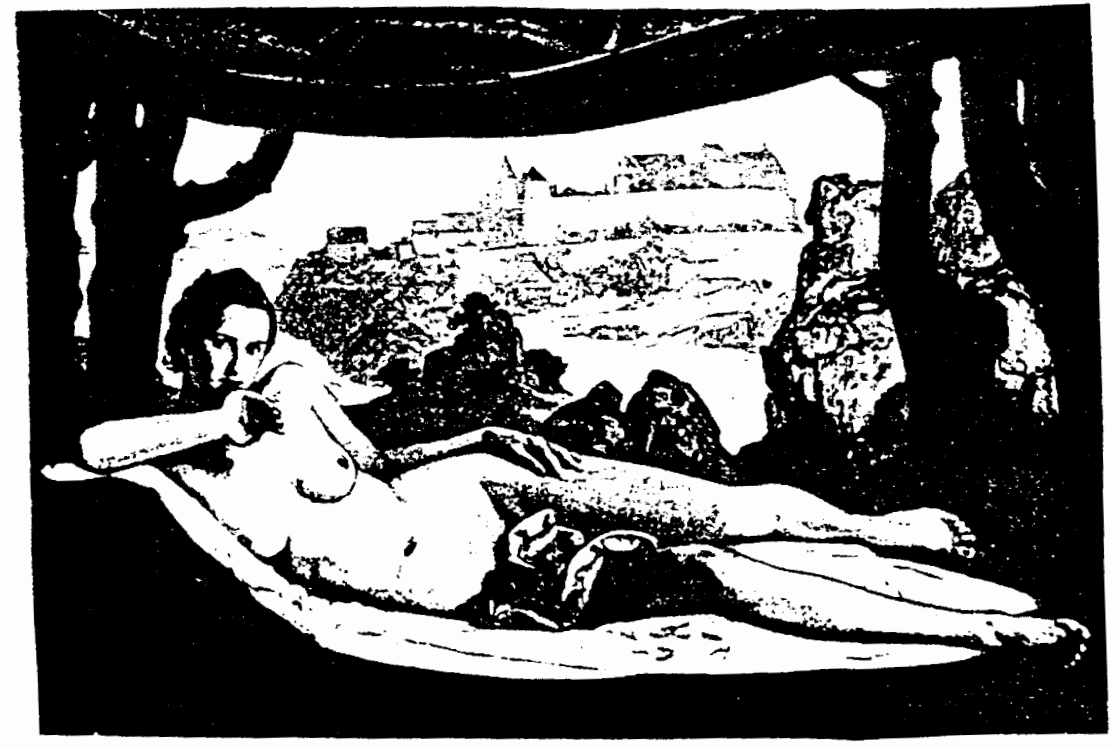

(16) Ernst Liebermann's, Lonely Heights, (no date) 


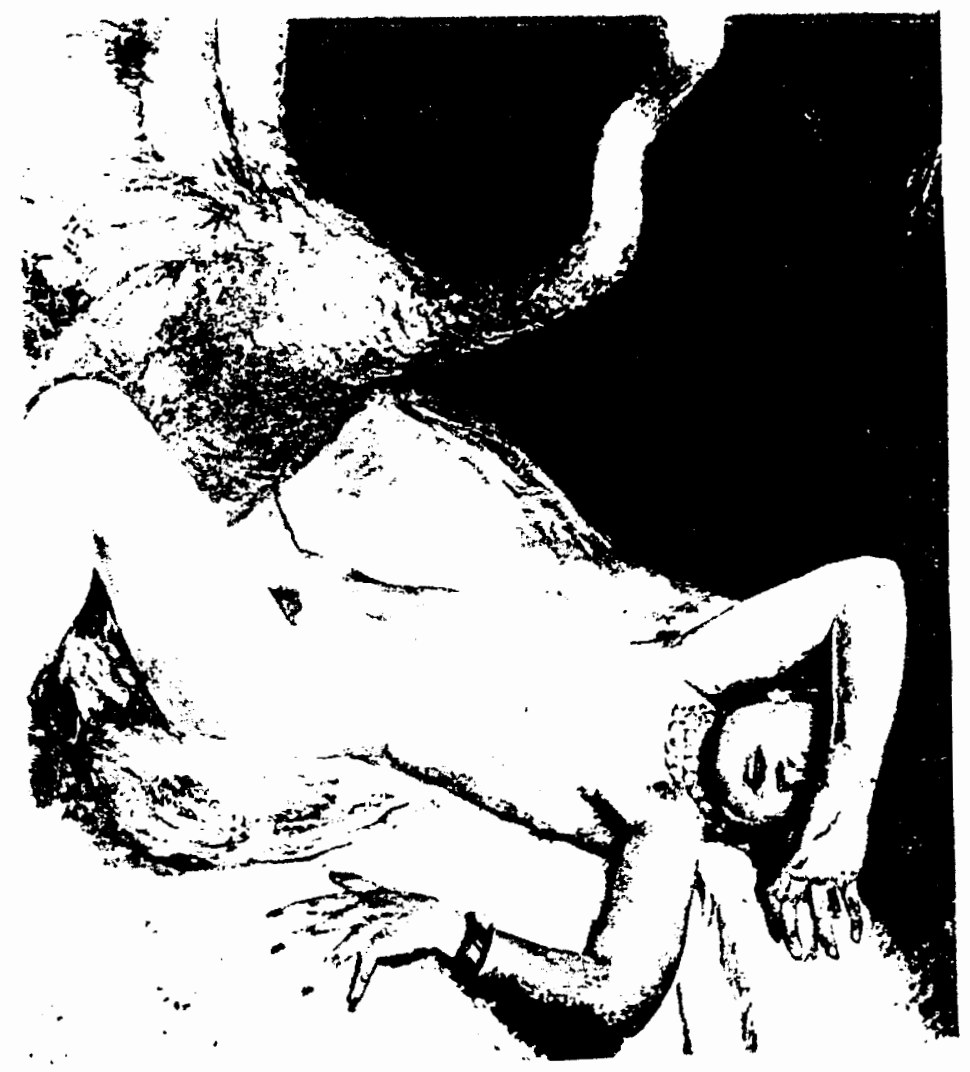

(17) Paul Mathias Padua's, Leda and the Swan, (no date) 


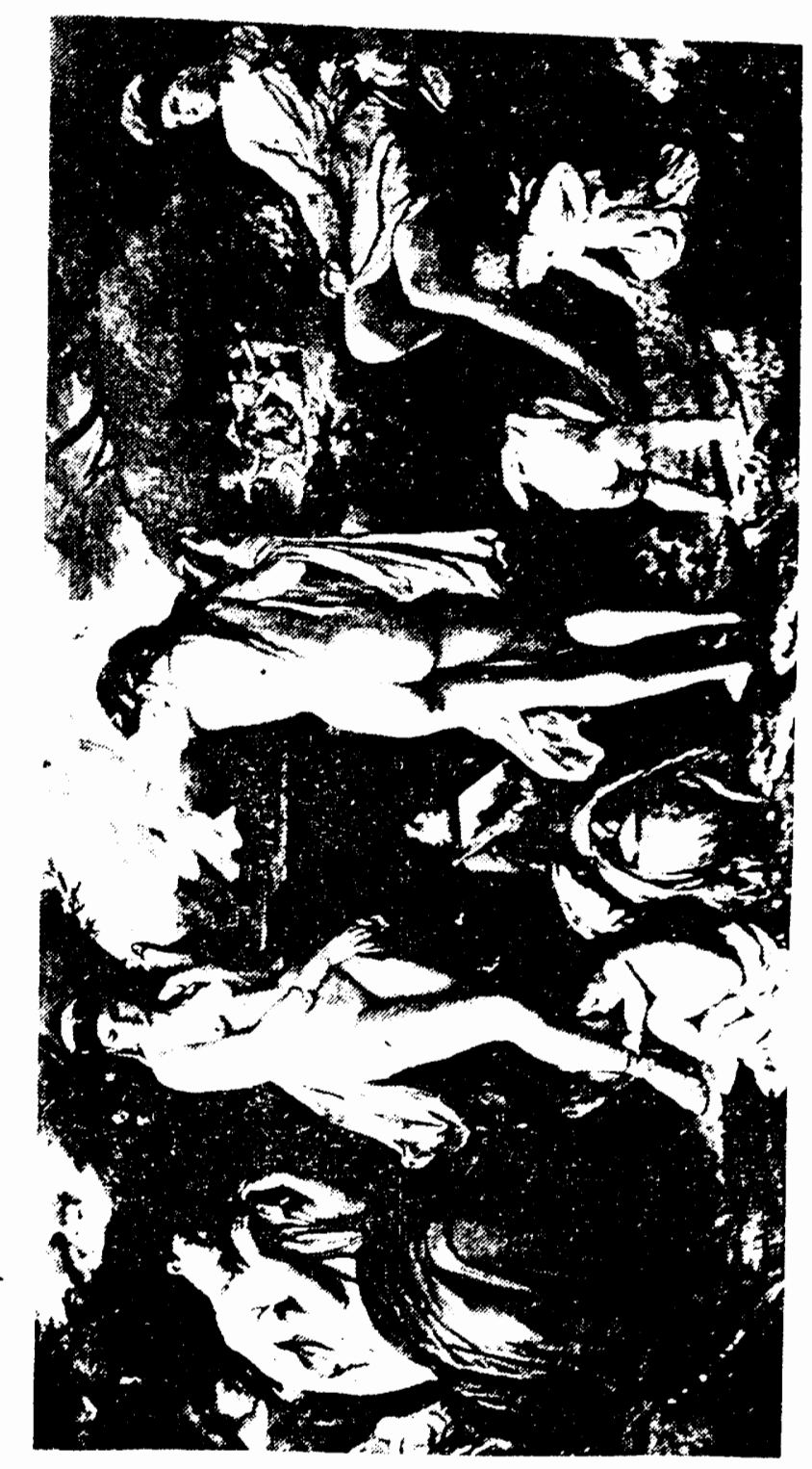

(19) Anslem Feuerbach's, Judgement of Paris, 1870 


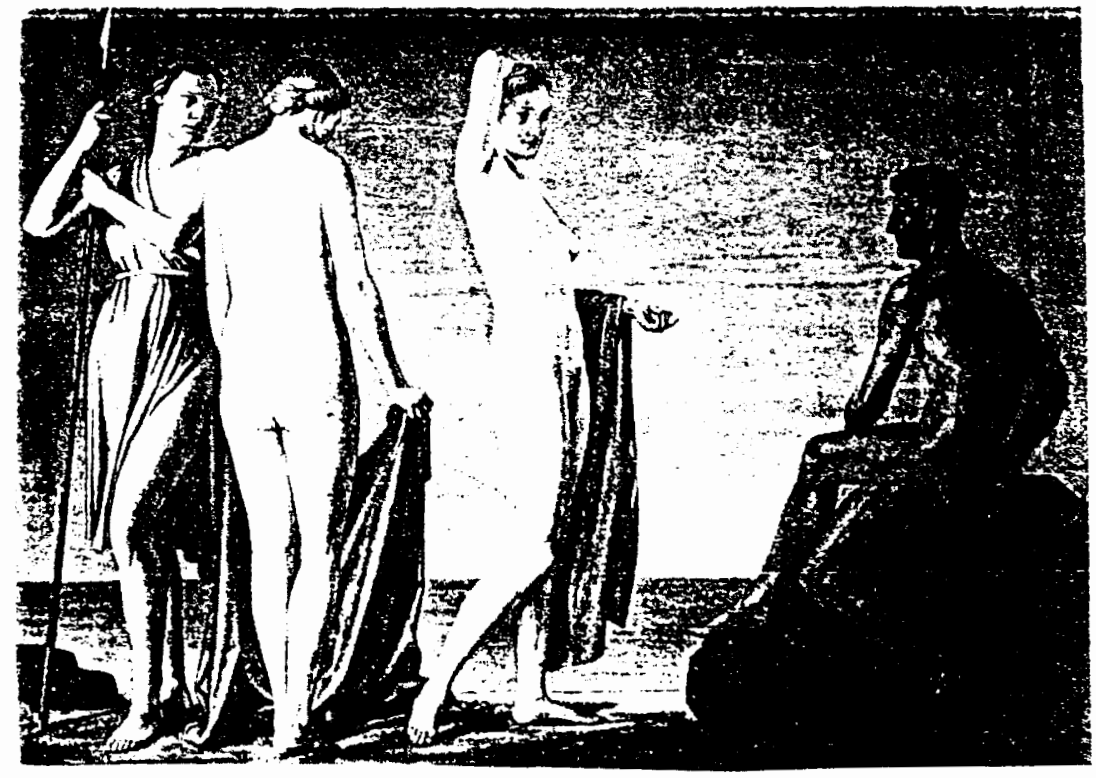

(20) Adolf Ziegler's, The Judgement of Paris, 1939 


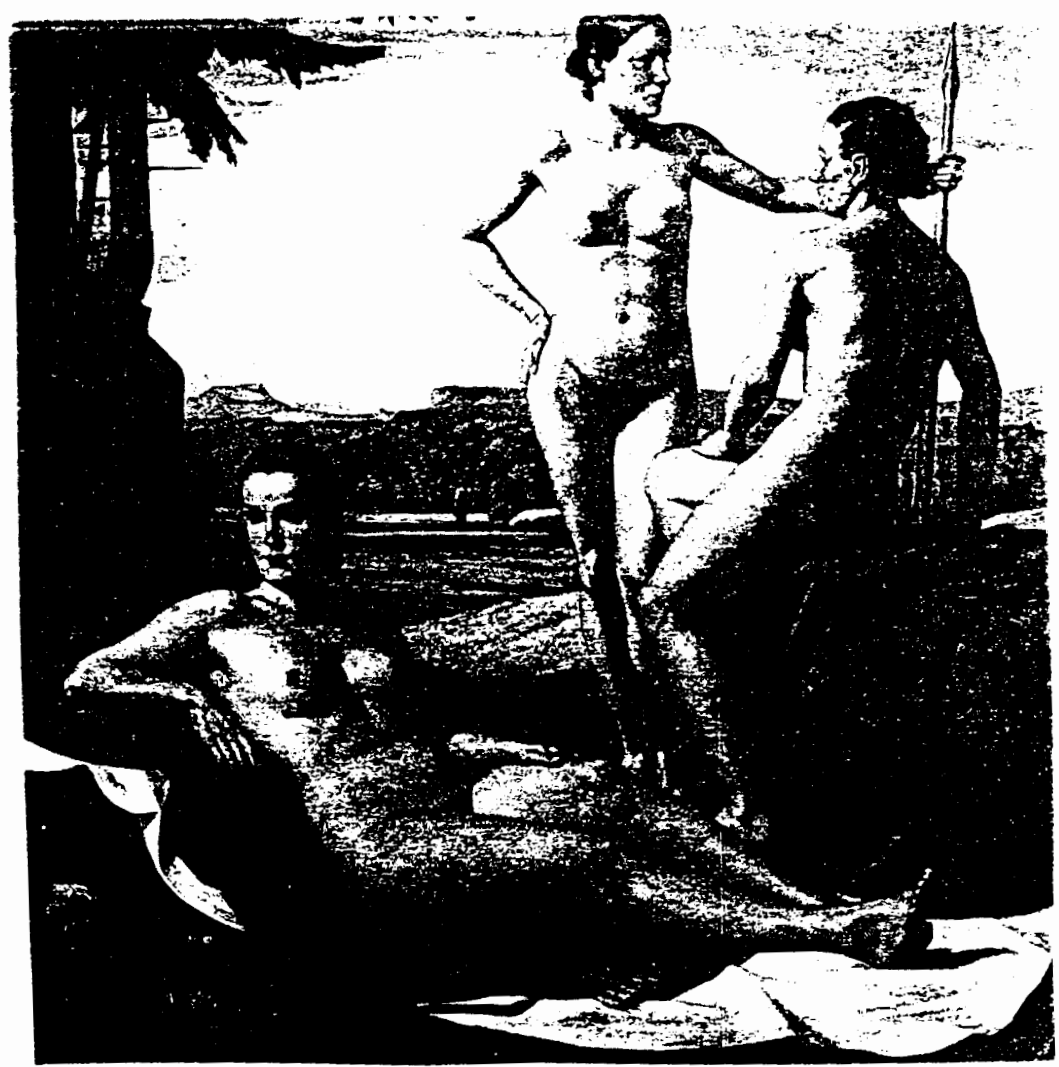

(21) Ivo Saliger's, Diana at Rest, 1939-40 


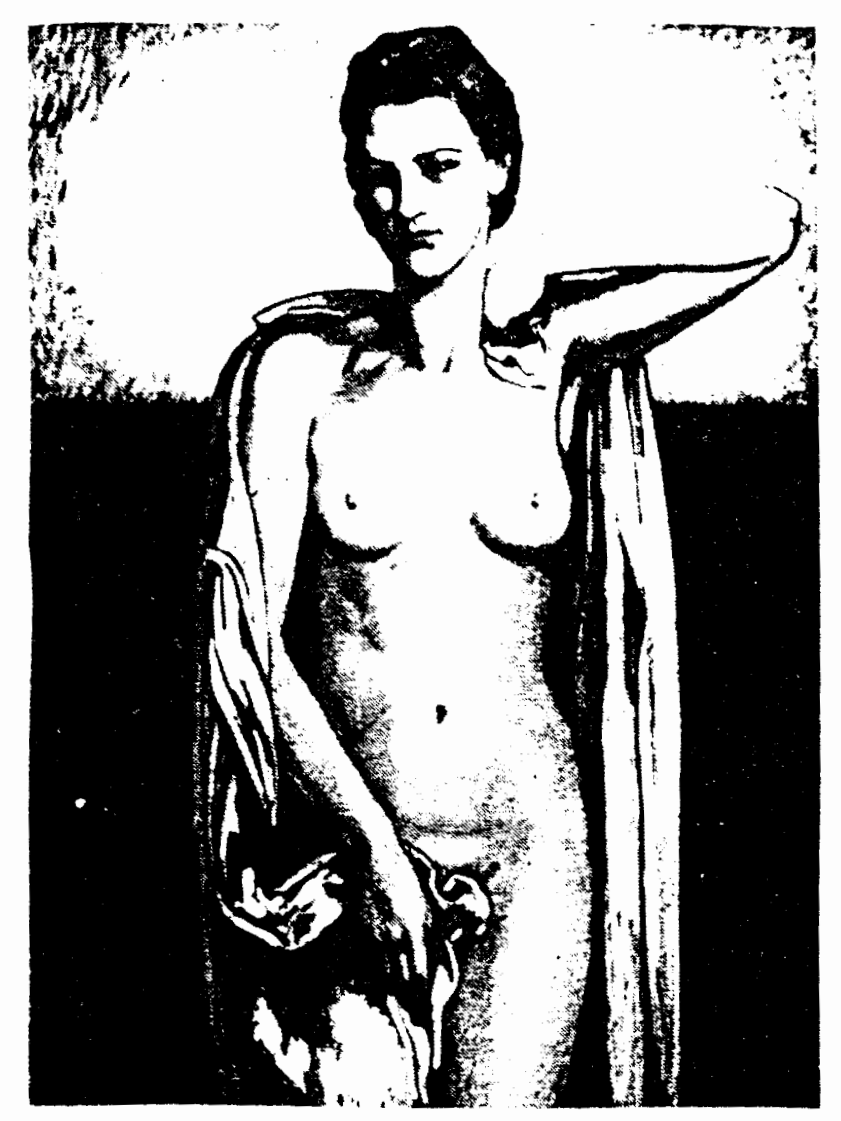

(22) Ernst Liebermann's, The Slave, (no date) 


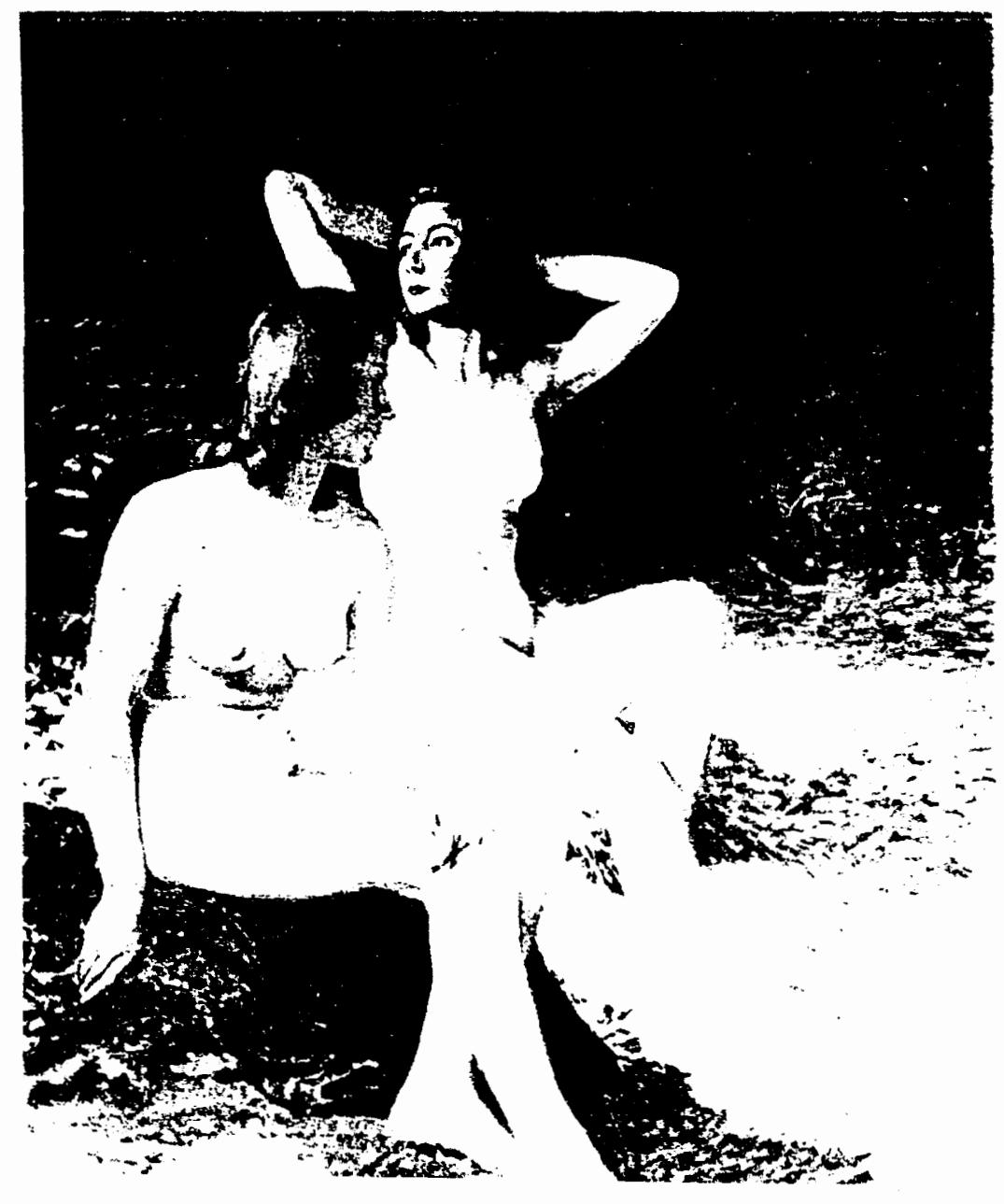

(23) Johann Schult's Expectation, (no date) 


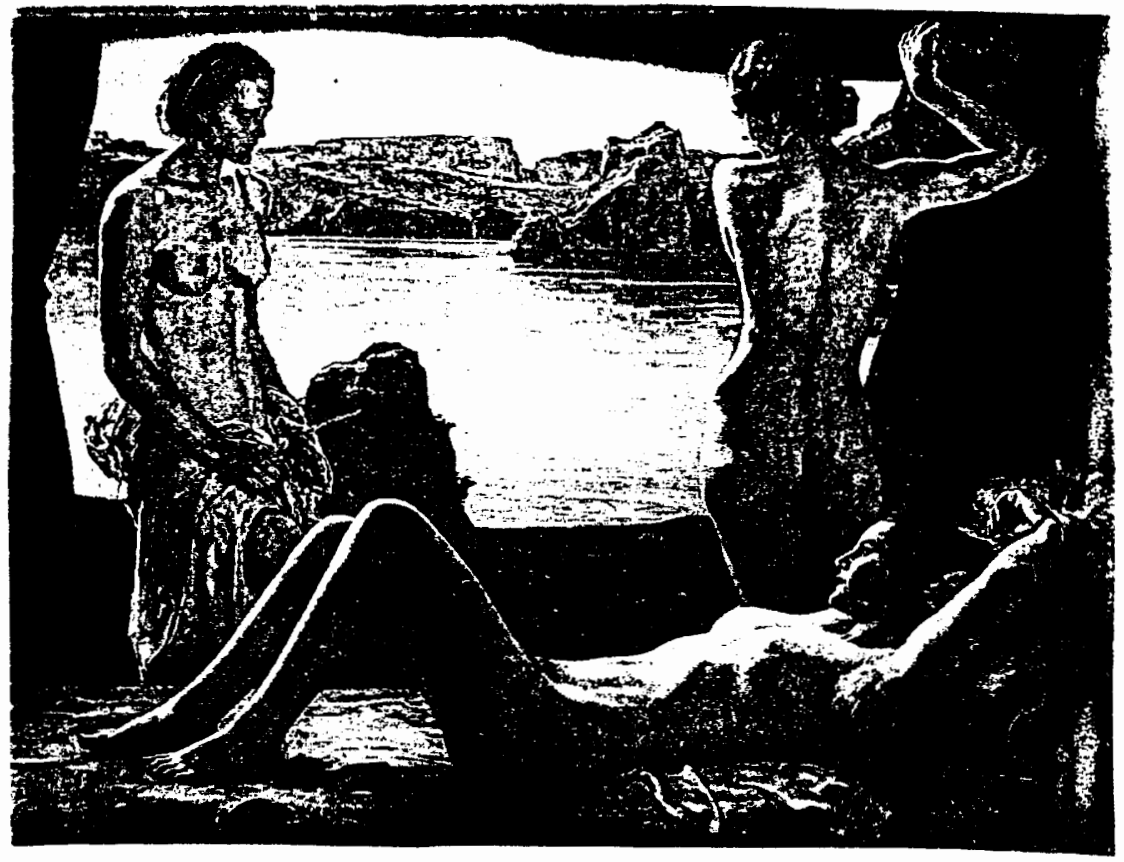

(24) Ernst Liebermann's, By the Water, (no date) 


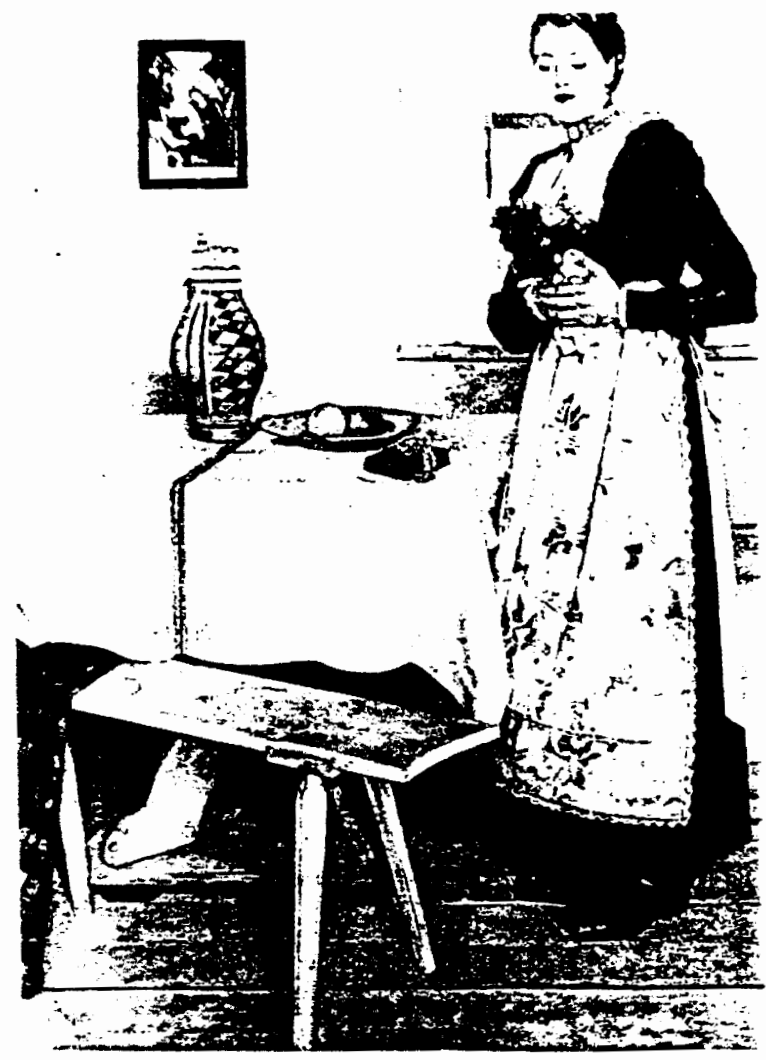

(25) Sepp Hilz', Peasant Bride, (no date) 


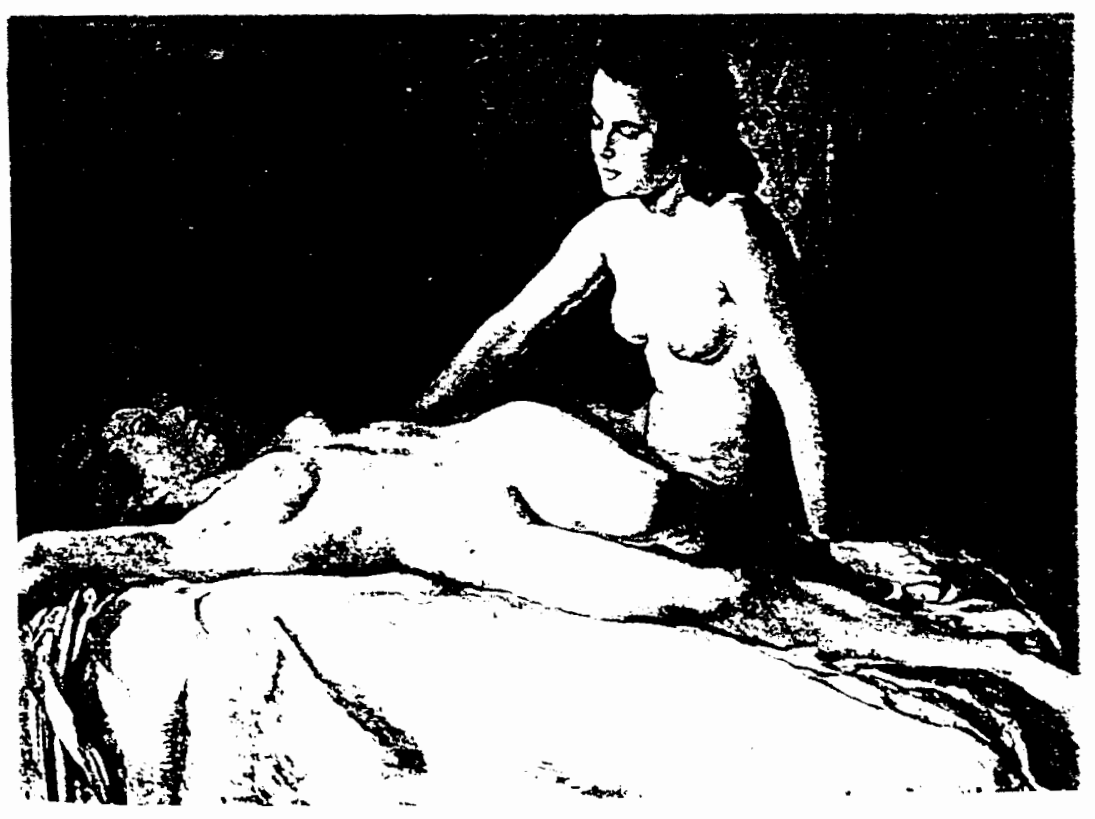

(26) Wilhelm Hempfing's, Youth, (no date) 